\title{
Neutronics Benchmark for the Quad Cities-1 (Cycle 2) Mixed-Oxide Assembly Irradiation
}

Computational Physics and Engineering Division

\section{RECEIVED \\ MAY 12 B \\ $08 \mathrm{TI}$}

S. E. Fisher

F. C. Difilippo

MASTER

WAMAEED ANO OPERATED BY LOCKHEED WATMN EREREY RESEARCH CORPORATION FOR THE UHTEO STATES

DEPATINENT OF ENERGY 
This report has been reproduced directly from the best available copy.

Available to DOE and DOE contractors from the Office of Scientific and Technical Information, P.O. Box 62, Oak Ridge, TN 37831; prices available from (615) 576-8401. FTS 626-8401.

Available to the public from the National Technical information Service, U.S. Department of Commerce, 5285 Port Royal Rd., Springfield, VA 22161.

This report was prepared as an account of work sponsored by an agency of the United States Government. Neither the United States Government nor any agency thereof, nor any of their employees, makes any warranty, express or implied, or assumes any legal liability or responsibility for the accuracy, completeness, or usetulness of any information, apparatus, product, or process disclosed, or represents that its use would not infringe privately owned rights. Reference herein to any specific commercial product, process, or senvice by trade name, trademark, manufacturer, or otherwise, does not necessarily constitute or imply its endorsement, recommendation, or favoring by the United States Government or any sgency thereof. The views and opinions of authors expressed herein do not necessarily state or reflect those of the United States Government or any agency thereof. 


\section{DISCLAIMER}

Portions of this document may be illegible electronic image products. Images are produced from the best available original document. 
Computational Physics and Engineering Division

\title{
Neutronics Benchmark for the Quad Cities-1 (Cycle 2) Mixed-Oxide Assembly Irradiation
}

S. E. Fisher

F. C. Difilippo

Date Published: April 1998

\author{
Prepared by the \\ OAK RIDGE NATIONAL LABORATORY \\ Oak Ridge, Tennessee 37831 \\ managed by \\ LOCKHEED MARTIN ENERGY RESEARCH CORPORATION \\ for the \\ U.S. DEPARTMENT OF ENERGY \\ under contract DE-AC05-96OR22464
}




\section{CONTENTS}

ABSTRACT,$\ldots \ldots \ldots \ldots \ldots \ldots \ldots \ldots \ldots \ldots \ldots \ldots \ldots \ldots \ldots \ldots \ldots \ldots \ldots \ldots \ldots \ldots$ vii

1. INTRODUCTION $\ldots \ldots \ldots \ldots \ldots \ldots \ldots \ldots \ldots \ldots \ldots \ldots \ldots \ldots \ldots \ldots \ldots \ldots$

2. PURPOSE AND OBJECTIVES OF THIS BENCHMARK $\ldots \ldots \ldots \ldots \ldots \ldots \ldots \ldots$

3. MODEL DESCRIPTION, MEASURED RESULTS, AND ORNL CALCULATED

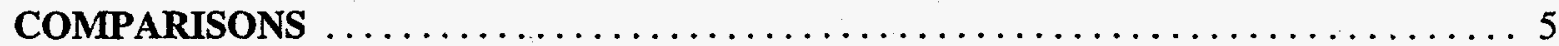

3.1 CALCULATIONAL MODEL INPUT FOR MOX ASSEMBLY GEB-161 $\ldots \ldots \ldots \ldots 5$

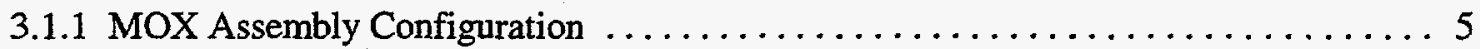

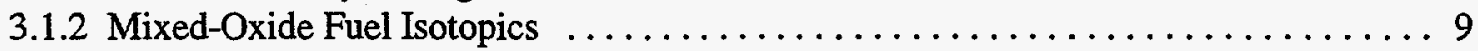

3.1.3 Adjoining Assemblies and Boundary Conditions $\ldots \ldots \ldots \ldots \ldots \ldots \ldots \ldots$

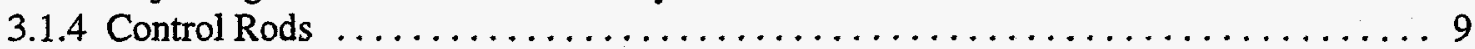

3.1.5 Power History Modeling for GEB-161 and Its Neighbors $\ldots \ldots \ldots \ldots \ldots \ldots$

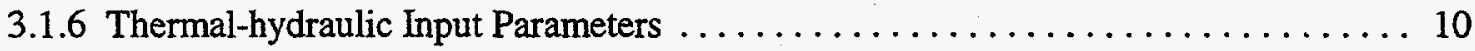

3.1 .7 Alloy Compositions for Nuclear Analyses $\ldots \ldots \ldots \ldots \ldots \ldots \ldots \ldots \ldots \ldots \ldots$

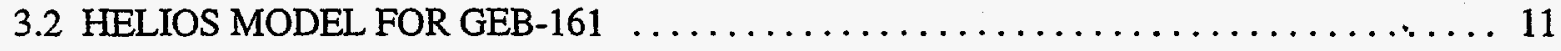

3.3 END-OF-CYCLE-2 MEASUREMENT INFORMATION AND HELIOS COMPARISON

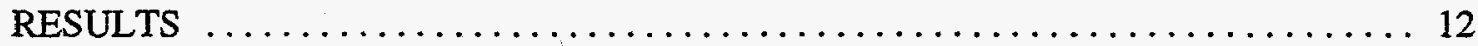

3.3.1 Destructive Isotopic Analysis-Gadolinium Analysis in a $\mathrm{UO}_{2} \operatorname{Rod}(\mathrm{F} 6) \ldots \ldots \ldots 12$

3.3.2 Destructive Isotopic Analysis-Uranium and Transuranics $\ldots \ldots \ldots \ldots \ldots \ldots \ldots$

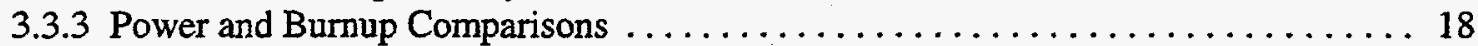

3.4 SCALE AND HELIOS COMPARISONS FOR SINGLE MOX AND UO $\mathrm{UO}_{2}$ RODS $\ldots \ldots \ldots 22$

3.5 OPTIONS FOR ADDITIONAL BENCHMARK CALCULATIONS $\ldots \ldots \ldots \ldots \ldots \ldots$

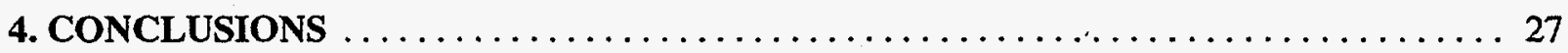

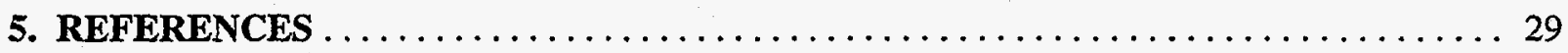

APPENDIX A. HISTORICAL ASSESSMENT OF QUAD CITIES (BWR) MOX

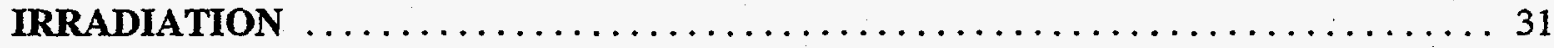

APPENDIX B. GEB-161 SURROUNDING ASSEMBLY DATA $\ldots \ldots \ldots \ldots \ldots \ldots \ldots \ldots$

APPENDIX C. ORNL HELIOS INPUT DECK LISTING $\ldots \ldots \ldots \ldots \ldots \ldots \ldots \ldots \ldots$

APPENDIX D. MEASURED AND CALCULATED VALUES OF ISOTOPICS,

RELATIVE PIN POWER, AND BURNUP BY PIN $\ldots \ldots \ldots \ldots \ldots \ldots \ldots \ldots \ldots$

APPENDIX E. SCALE INPUT LISTING $\ldots \ldots \ldots \ldots \ldots \ldots \ldots \ldots \ldots \ldots \ldots \ldots \ldots \ldots \ldots$ 


\section{LIST OF FIGURES}

\section{Figure}

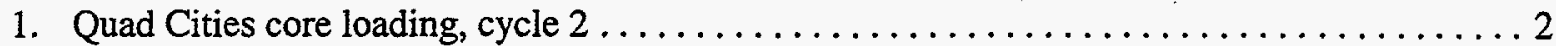

2. Quad Cities MOX central bundle GEB-161 [ref: EPRI NP-2307LD; rod types (i.e., numeric

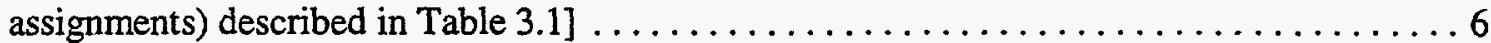

3. Assemblies adjoining GEB-161 (at BOC2) and lattice dimensions (in.) $\ldots \ldots \ldots \ldots \ldots 7$

4. HELIOS calculational model showing the calculated flux regions $\ldots \ldots \ldots \ldots \ldots \ldots \ldots$

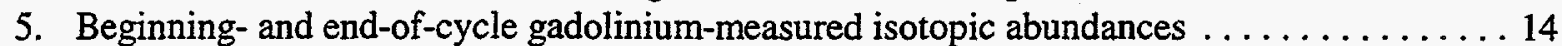

6. Calculated-to-measured values for gadolinium in pin $\mathrm{F} 6 \ldots \ldots \ldots \ldots \ldots \ldots \ldots$

7. Calculated (HELIOS)-to-measured comparisons (four rod representations for $\mathrm{MOX}$ and $\mathrm{UO}_{2}$ )

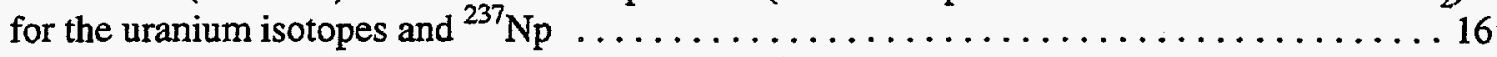

8. Calculated (HELIOS)-to-measured comparisons (four rod representations for $\mathrm{MOX}$ and $\mathrm{UO}_{2}$ )

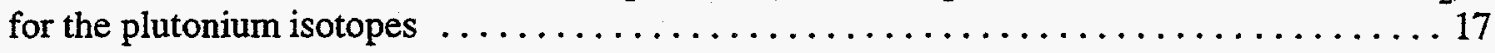

9. Calculated (HELIOS)-to-measured comparisons (four rod representations for $\mathrm{MOX}$ and $\mathrm{UO}_{2}$ )

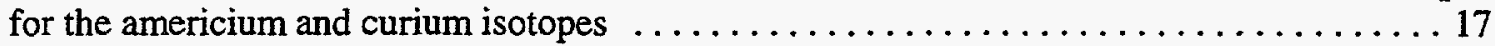

10. Calculated (HELIOS)-to-measured relative isotopic ratio comparisons (four rod representations for $\mathrm{MOX}$ and $\mathrm{UO}_{2}$ ) for the americium and curium isotopes $\ldots \ldots \ldots \ldots 18$

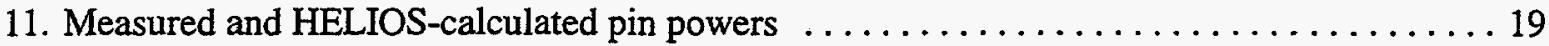

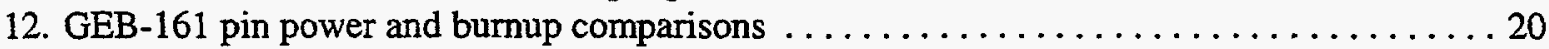

13. GEB-161 MOX and $\mathrm{UO}_{2} \mathrm{HELIOS}$ calculated-to-measured ratios for neodymium, pin powers

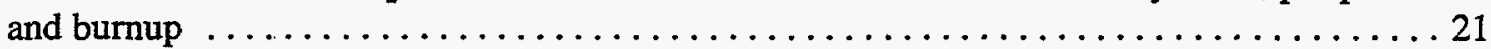

14. Calculated-to-measured ratios (SCALE and HELIOS) for GEB-161 MOX pin D5 ..... 23

15. Calculated-to-measured ratios (SCALE and HELIOS) for GEB-161 $\mathrm{UO}_{2}$ pin $\mathrm{C} 2 \ldots \ldots 24$

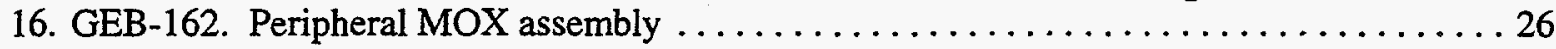




\section{LIST OF TABLES}

$\underline{\text { Table }}$

$\underline{\text { Page }}$

2.1. Quad Cities measurements ............................. 4

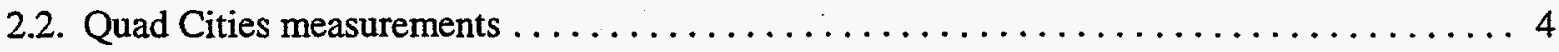

3.1. Composition of MOX bundle GEB-161 $\ldots \ldots \ldots \ldots \ldots \ldots \ldots \ldots \ldots \ldots \ldots \ldots$

3.2. Dimensional description of MOX lattice $\ldots \ldots \ldots \ldots \ldots \ldots \ldots \ldots \ldots \ldots \ldots \ldots$

3.3. Plutonium and uranium at. \% isotopics in MOX fuel $\ldots \ldots \ldots \ldots \ldots \ldots \ldots \ldots$

3.4. Fuel types for adjacent assemblies $\ldots \ldots \ldots \ldots \ldots \ldots \ldots \ldots \ldots \ldots \ldots \ldots$

3.5. Thermal-hydraulic parameters for 21 in. above bottom of fuel (node 4) $\ldots \ldots \ldots \ldots 10$

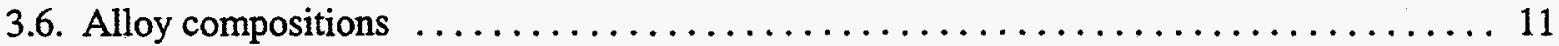





\begin{abstract}
Reactor physics computer programs are important tools that will be used to estimate mixed oxide fuel (MOX) physics performance in support of weapons grade plutonium disposition in U.S. and Russian Federation reactors. Many of the computer programs used today have not undergone calculational comparisons to measured data obtained during reactor operation. Pin power, the buildup of transuranics, and depletion of gadolinium measurements were conducted (under Electric Power Research Institute sponsorship) on uranium and MOX pins irradiated in the Quad Cities-1 reactor in the 1970's. These measurements are compared to modern computational models for the HELIOS and SCALE computer codes. Good agreement on pin powers was obtained for both MOX and uranium pins. The agreement between measured and calculated values of transuranic isotopes was mixed, depending on the particular isotope.
\end{abstract}




\section{INTRODUCTION}

A goal of the Fissile Materials Disposition Program (FMDP) is to dispose of weapons-grade plutonium in light-water reactors. Reactor physics computer programs and data are used to estimate reactor performance when mixed-oxide (MOX) fuel is substituted for low-enriched uranium (LEU) fuel. "Good engineering practice" and Nuclear Regulatory Commission (NRC) regulations require that physics codes and data be validated with applicable experimental data. Benchmarking computational methods with the measured data from the past provides confidence in the capabilities of modern calculational methods.

The U.S. program associated with the use of mixed-oxide (MOX) fuel in Boiling-Water Reactors (BWRs) started with a series of irradiations in the Vallecitos BWR. The testing proceeded with the irradiation of rods containing Dresden self-generated plutonium. Four MOX bundles containing a single MOX rod per bundle were inserted into Dresden 1 in 1967. However, the major irradiation programs involving U.S. commercial BWRs occurred in the Big Rock Point and Quad Cities-1 reactors (ORNL/MD/LTR 40). A description, history, and an evaluation of potential benchmarks associated with the Quad Cities-1 BWR MOX fuel are presented in Appendix A.

The Quad Cities irradiation involved the collection of detailed performance data for five MOX bundles using 80 and $90 \%$ fissile plutonium rods mixed in with conventional LEU rods. Even though these five assemblies are not all MOX, they will be referred to as MOX assemblies in this report. Note that "global" parameters are not the focus of this benchmark, since the five bundles containing MOX did not significantly affect overall core performance. With respect to physics parameters that are more global in nature (such as overall core reactivity and critical rod height predictions), the Big Rock Point Reactor irradiations are more relevant.

BWR fuel designs have changed during the last 20 years, and these changes somewhat diminish the direct applicability of the Quad Cities irradiation to the new MOX fuel designs considered in the FMDP. Nevertheless, the Quad Cities irradiation and subsequent post irradiation examination (PIE) constitute the most recent body of U.S. experimental data and remain the best domestic prototypical reactor measurements associated with the insertion of high-fissile plutonium MOX fuel in a BWR.

The term "reactor physics benchmark" generally refers to the application of methods to a pin level or few assembly calculation. Generally, these types of benchmarks are concerned with locallevel phenomena, such as pin powers, assembly k-infinity, etc.. A comparison is usually made to a more exact calculation or (preferably) to an accurate physical measurement. Because the primary objective of the work described here is to compare against measured, post-irradiation data, the term benchmark is also applied. The primary intent of this benchmark is to focus on MOX pin neutronic performance in a mixed lattice of $\mathrm{UO}_{2}$ and MOX pins. These parameters are compared for a single, assembly-level calculation in which approximately $20 \%$ of the pins are $\mathrm{MOX}$ pins surrounded by $\mathrm{UO}_{2}$ pins.

Figure 1 shows a cross section of the Quad Cities-1 core. This diagram indicates the location of the four central MOX bundles and the peripheral bundle that were irradiated during cycle 2 . A number of measurements were conducted at the end of cycle 2. However, a review of the literature makes it clear that one of the major objectives of the Quad Cities MOX irradiations was to obtain measured data that could be used for benchmarks of power distributions. 


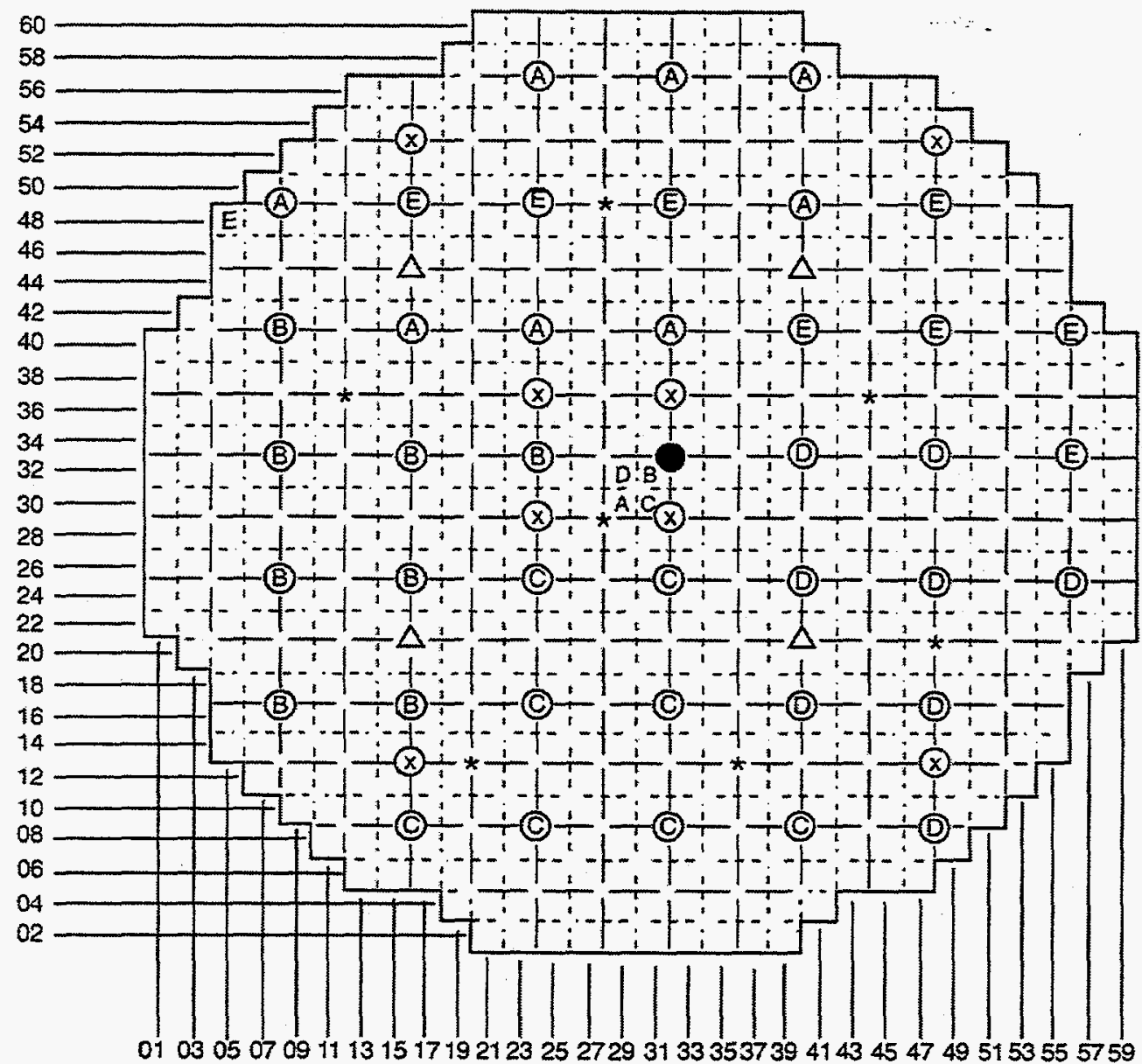

LOCALPOWER RANGE MONTTOR

(A) LPRM LOCATION (LETTER INDICATES TIP MACHINE)

- LPAM LOCATION (COMMON LOCATION FORALL TIP MACHINES)

( $)$ INTERMEDIATE PAGE MONITOR IRM LOCATION

$\triangle$ SOURCE RANGE MONITOR SRM LOCATIONS

* Source locations

a THE $\triangle$ DESIGNATION BECAME M AFTER ROD SWAPS AFTER THE FIRST CYCLE OF IRRADIATIONS

b CHANNEL 32572 REPLACED WITH CHANNEL 82818 AT EOC4

\begin{tabular}{c} 
MO2 \\
BUNDLENUMBER \\
\hline A GEB158 $\triangle$ \\
A GEB159 $\triangle$ \\
A GEB160 $\triangle$ \\
A GEB161M \\
A GEB162M
\end{tabular}

$B P C 2-E O C 5$

BECAME "R" DESIGNATIONAFTER ROO SWAPS DURING EOC5 REFUELING OUTAGE

\begin{tabular}{|c|c|}
\hline - GEBI58R & 32616 \\
\hline B GEBI59R & 32610 \\
\hline - GEBIGO $\triangle$ & 3246 \\
\hline GEBIG1R ${ }^{C}$ & 32521 \\
\hline E GEBI62M & 82818 \\
\hline
\end{tabular}

POOLSTORAGE 31-32 POOL STORAGE POOL STORAGE $5-48$

Fig. 1. Quad Cities core loading, cycle 2 (ref: EPRI-NP-3568). 


\section{PURPOSE AND OBJECTIVES OF THIS BENCHMARK}

Starting in the mid 1970s and lasting into the early 1980 s, a number of measurements were conducted on the Quad Cities fuel. Tables 2.1 and 2.2 below (taken from ref. EPRI-NP-3568) show the full extent of the planned measurements. Insofar as cycle 2, 3, and 4 measurements are concerned, the information is publicly available and was funded by the Electric Power Research Institute (EPRI). The full extent of the measurements that were actually taken is not known. It is likely that some measurements fall within the scope of EPRI funding and some were funded by General Electric (GE) and are therefore considered proprietary data. To date, the major publicly available results that have been found are the end-of-cycle (EOC) 2 PIE measurements and the gamma scanning of the MOX bundles.

The present analysis for this benchmark takes in to account only the cycle 2 measurements. It is important to remember that this benchmark was constructed from incomplete information. Specifically, the thermal-hydraulic conditions of the core, which change over the cycle, were assumed fixed and some parameters were estimated. The average of the measured burnup data was used as an input into the calculation. Because of the lack of void history data, the studies were conducted on the fuel samples taken near the bottom of the core, where there was a higher confidence level in the value for the void fraction (e.g., near 0). This area is also more applicable to the analysis of pressurizedwater reactors (PWR) than the higher void fraction regions that exist higher up in the core.

This benchmark represents the first step of an approach that will be taken with respect to the construction of future benchmarks (e.g., with the availability of related measurements, the remaining cycles will be analyzed, extending to $57,000 \mathrm{MWd} / \mathrm{t}$-the peak burnup achieved). Depending on the availability of additional core operating information, other important parameters could be benchmarked. The current understanding is that much of the benchmark information with respect to Quad Cities is contained in a proprietary topical report that was sent to NRC in the early 1980s (GECONVER). With respect to this reactor physics benchmark, based on the publicly available information, it was decided that pin power, burnups and transuranic isotopic comparisons in a MOX assembly would be examined. This comparison will be for one cycle of burnup. Options associated with other possible benchmarks are discussed in Sect. 3.5. 
Table 2.1. Quad Cities measurements ${ }^{a}$ (from EPRI NP-3568, July 1984)

\begin{tabular}{|c|c|c|c|c|c|}
\hline & Cycle 2 & Cycle 3 & Cycle 4 & Cycle 5 & Cycle $6^{b}$ \\
\hline \multicolumn{6}{|l|}{ Irradiation history } \\
\hline Avg. bundle burnup $G W d / t$ & 9.1 & 15.0 & 23.5 & 31.4 & 39.7 \\
\hline Peak pellet burnup, GWd/t & 16.0 & 23.3 & 34.2 & 45.3 & 57.3 \\
\hline Peak pellet $\mathrm{LHGR},{ }^{c} \mathrm{~kW} / \mathrm{ft}$ & 15.4 & 11.6 & 11.0 & 10.0 & 9.0 \\
\hline \multicolumn{6}{|l|}{ EOC site measurements } \\
\hline Bundle gamma scans & Octant +5 & $\rightarrow^{d}$ & & Octant $+5^{a}$ & Octant $+5^{a}$ \\
\hline Rod-by-rod gamma scans & 2 Bundles & $\rightarrow^{d}$ & & 1 Bundle $^{a}$ & 1 Bundle $^{a}$ \\
\hline Cold crit./wire activation & & Yes & & & \\
\hline Neutrography ${ }^{d}$ & & & & 13 Rods & 7 Rods $^{e}$ \\
\hline \multicolumn{6}{|l|}{ EOC hot-cell measurements } \\
\hline Heavy-element isotopic conc. & 15 Rods & & & $5 \operatorname{Rods}^{b}$ & 5 Rods $^{b}$ \\
\hline Burnup (Nd-148) & 15 Rods & & & $5 \operatorname{Rods}^{b}$ & $5 \operatorname{Rods}^{b}$ \\
\hline Radial pellet burnup/isotopics & 4 Pellets & & & & 2 Pellets ${ }^{b}$ \\
\hline Gd isotopics & 11 Pellets & & & & \\
\hline Neutrography ${ }^{d}$ & 8 Rods/8 Pellets & & & & \\
\hline Fission product absorbers & & & & & 8 Pellets $^{b}$ \\
\hline \multicolumn{6}{|c|}{$\begin{array}{l}{ }^{a} \text { Fuel extensively precharacterized (isotopic composition, neutrography, electron microprobe, etc.) } \\
{ }^{b} \text { Measurements completed by GE outside the EPRI contract. } \\
{ }^{c} \text { LHGR = Linear heat generation rate. } \\
{ }^{d} \text { Source documentation and history of this measurement is not ciear. } \\
{ }^{e} \text { Measurements believed outside the EPRI contract. It is not known if these measurements were actually } \\
\text { performed. }\end{array}$} \\
\hline \multicolumn{6}{|c|}{$\begin{array}{l}\text { Table 2.2. Quad Cities measurements } \\
\text { (from EPRI NP-3568, July 1984) }\end{array}$} \\
\hline & Cycle 2 & Cycle 3 & Cycle 4 & Cycle 5 & Cycle 6 \\
\hline \multicolumn{6}{|l|}{ EOC site measurements } \\
\hline Rod profilometry & 28 Rods & 28 Rods & 27 Rods & 27 Rods & 24 Rods $^{b}$ \\
\hline Rod visual and NDT inspection ${ }^{a}$ & 28 Rods & 28 Rods & 27 Rods & 27 Rods & $24 \operatorname{Rods}^{b}$ \\
\hline Rod length & 28 Rods & 77 Rods & 75 Rods & 83 Rods & $24 \operatorname{Rods}^{b}$ \\
\hline $\begin{array}{l}\text { Channel bulge, bow, flatness, } \\
\text { displacement, and corrosion }\end{array}$ & \multicolumn{4}{|c|}{$\leftarrow 5$ Channels + Peripheral $\rightarrow$} & 2 Chan. $^{b}$ \\
\hline Neutrography & & & & 13 Rods & $7 \operatorname{Rods}^{b}$ \\
\hline Fission-gas puncturing & & & & & 10-24 Rods ${ }^{b}$ \\
\hline Fuel rod corrosion & & & & & 10 Rods $^{b}$ \\
\hline \multicolumn{6}{|l|}{ EOC hot cell measurements } \\
\hline Burnup gamma scans & & & & 5 Rods & $5 \operatorname{Rods}^{b}$ \\
\hline Fuel isotopics and burnup & 15 Rods & & & 5 Rods $^{b}$ & 5 Rods $^{b}$ \\
\hline Fission gas & 2 Rods & & & 5 Rods & $5 \operatorname{Rods}^{b}$ \\
\hline Neutrography & 8 Rods & & & & 5 Rods $^{b}$ \\
\hline Corrosion & & & & & $5 \operatorname{Rods}^{b}$ \\
\hline
\end{tabular}

${ }^{\mathrm{a}} \mathrm{NDT}=$ nondestructive testing.

${ }^{b}$ Measurements tentatively being considered that were outside the EPRI contract at the time. 


\section{MODEL DESCRIPTION, MEASURED RESULTS, AND ORNL CALCULATED COMPARISONS}

This section contains information used as input to the calculational model. The model itself and the comparison of the measured results with the calculations are provided. The measurement uncertainites, which are dependent on the type of measurement, are discussed in the comparisons. Finally, options associated with the composition of future benchmarks based on the MOX experience at Quad Cities-1 are presented.

\subsection{CALCULATIONAL MODEL INPUT FOR MOX ASSEMBLY GEB-161}

A description of the input data for the calculational model is presented subsequently. Details provided include a description of the four central MOX fuel assemblies and the surrounding uranium fueled assemblies. Initial isotopics, the irradiation history, and a description of the lattice geometry are included. Experimental uncertainties are discussed in Sect. 3.3.2.

\subsubsection{MOX Assembly Configuration}

Figure 2 shows the MOX central bundle designated GEB-161. The shaded locations are the $\mathrm{MOX}, \mathrm{UO}_{2}$, and $\mathrm{UO}_{2} / \mathrm{Gd}$ pins that were subjected to post-irradiation measurements. Table 3.1 shows the fuel pin stack arrangement for GEB-161. Assembly dimensions are provided in Table 3.2 and Fig. 3. Note that Fig. 2 should be rotated counterclockwise in order to fit the arrangement shown in Fig. 3. 


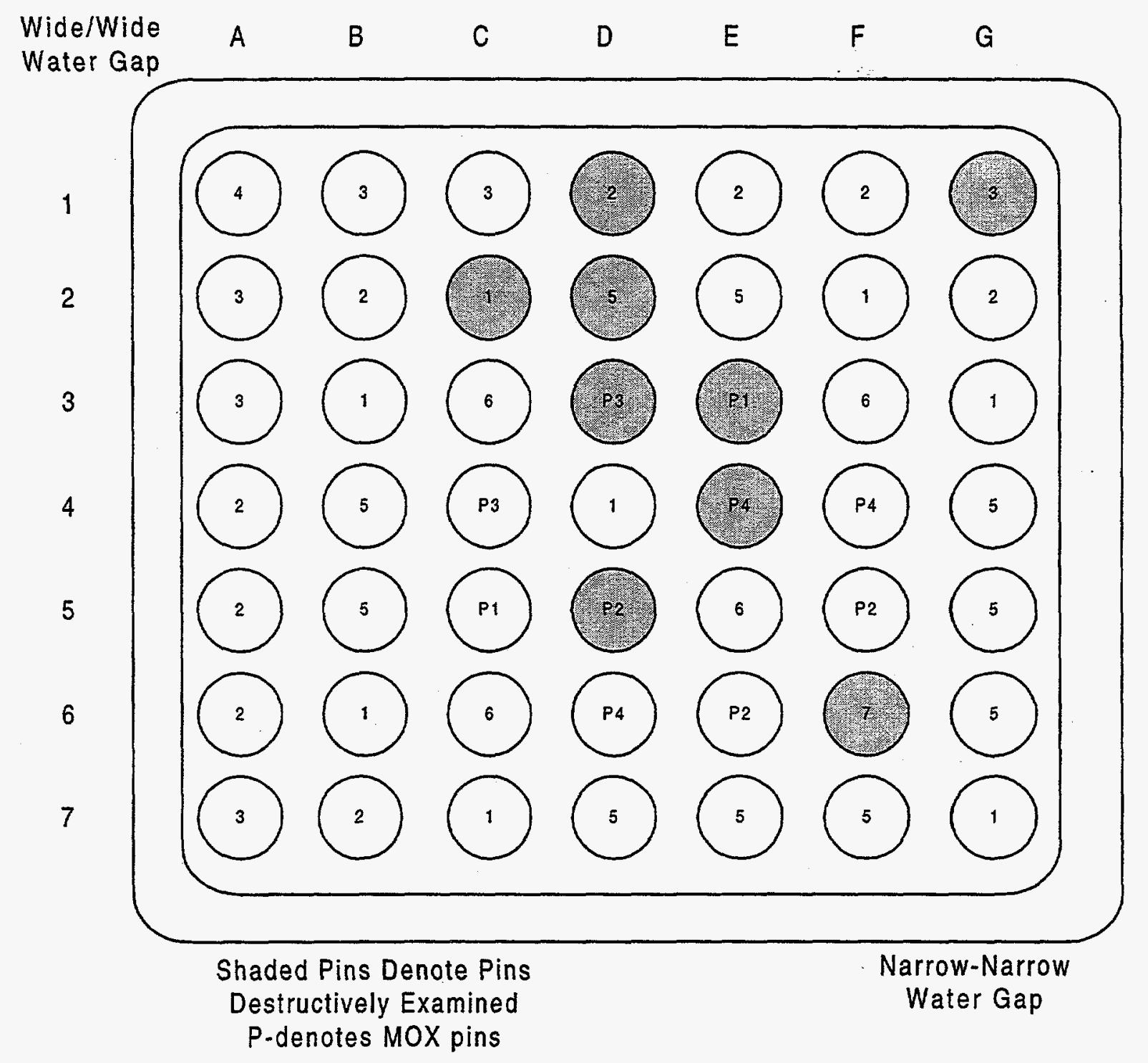

Fig. 2. Quad Cities MOX central bundle GEB-161 [ref: EPRI NP-2307LD; rod types (i.e., numeric assignments) described in Table 3.1]. 


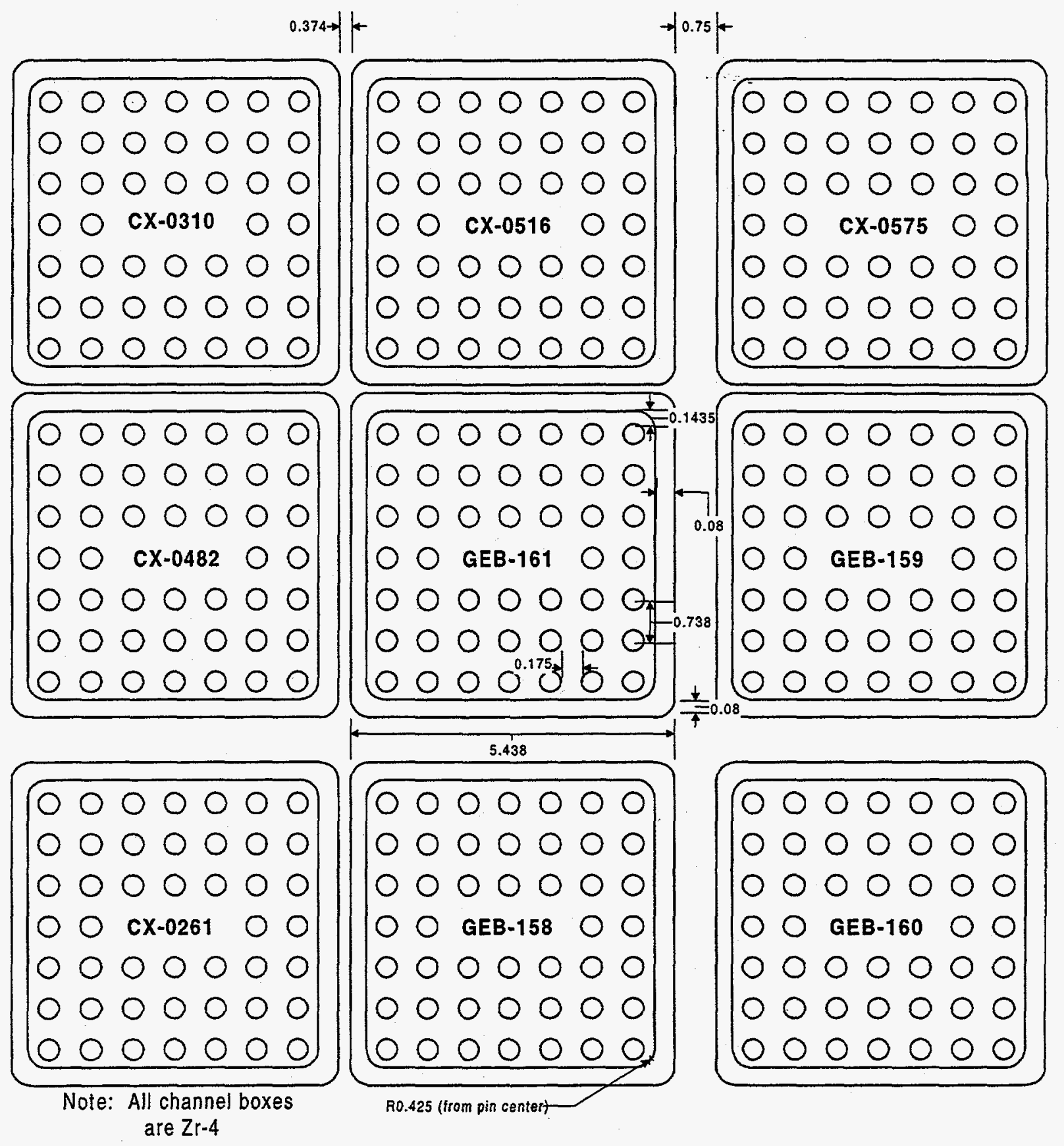

Fig. 3. Assemblies adjoining GEB-161 (at BOC2) and lattice dimensions (in.). 
Table 3.1. Composition of MOX bundle GEB-161

(assembly type 5, ref: EPRI NP-240, p. A-6)

\begin{tabular}{|c|c|c|c|c|c|c|c|c|}
\hline \multirow{2}{*}{ Rod type } & \multirow[b]{2}{*}{$\begin{array}{c}\text { No. of } \\
\text { rods }\end{array}$} & \multirow[b]{2}{*}{$\begin{array}{c}{ }^{235} U \\
\text { (wt \% of } U) \\
\end{array}$} & \multirow[b]{2}{*}{$\begin{array}{c}\text { Fissile Pu } \\
\text { (wt \%) }\end{array}$} & \multirow[b]{2}{*}{$\begin{array}{l}\mathrm{Gd}_{2} \mathrm{O}_{3} \\
(\mathrm{wt} \%) \\
\end{array}$} & \multirow[b]{2}{*}{$\begin{array}{c}\text { Stack } \\
\text { density } \\
\left(\mathrm{g} / \mathrm{cm}^{3}\right)\end{array}$} & \multirow[b]{2}{*}{$\begin{array}{l}\text { Pellet } \\
\text { O.D. } \\
\text { (in.) }\end{array}$} & \multicolumn{2}{|c|}{ Zirc-2 clad } \\
\hline & & & & & & & OD (in.) & $\begin{array}{l}\text { Wall } \\
\text { thickness } \\
\text { (in.) }\end{array}$ \\
\hline 1 & 8 & 2.56 & 0 & 0 & 10.32 & 0.477 & 0.563 & 0.037 \\
\hline 2 & 9 & 1.94 & 0 & 0 & 10.32 & 0.477 & 0.563 & 0.037 \\
\hline 3 & 6 & 1.69 & 0 & 0 & 10.32 & 0.477 & 0.563 & 0.037 \\
\hline 4 & 1 & 1.33 & 0 & 0 & 10.32 & 0.477 & 0.563 & 0.037 \\
\hline 5 & 10 & 3.30 & 0 & 0 & 10.32 & 0.477 & 0.563 & 0.037 \\
\hline 6 & 4 & 2.56 & 0 & 3.0 & 10.19 & 0.477 & 0.563 & 0.037 \\
\hline 7 & 1 & 2.56 & 0 & 2.5 & $10.19^{d}$ & 0.477 & 0.563 & 0.037 \\
\hline P1 (solid) & 2 & 0.72 & $2.14^{b}$ & 0 & $9.89^{e}$ & 0.487 & 0.563 & 0.032 \\
\hline P2 (solid) & 3 & 0.72 & $3.52^{c}$ & 0 & $9.89^{e}$ & 0.487 & 0.563 & 0.032 \\
\hline P3 (annul-0.15 ID) & 2 & 0.72 & $2.34^{b}$ & 0 & $8.94^{e}$ & 0.487 & 0.563 & 0.032 \\
\hline P4 (annul-0.15 ID) & 3 & 0.72 & $3.62^{c}$ & 0 & $8.94^{e}$ & 0.487 & 0.563 & 0.032 \\
\hline
\end{tabular}

${ }^{\circ} \mathrm{OD}=$ outside diameter.

${ }^{b} 80 \%$ Fissile blend, see following section. Fissile $\mathrm{Pu}$ is weight of ${ }^{239} \mathrm{Pu}$ and ${ }^{241} \mathrm{Pu}$ divided by total heavy metal based on Fig. 3.2, EPRI NP-2307-LD.

${ }^{c} 90 \%$ Fissile blend, see following section. Fissile $\mathrm{Pu}$ is weight of ${ }^{239} \mathrm{Pu}$ and ${ }^{241} \mathrm{Pu}$ divided by total heavy metal based on Fig. 3.2, EPRI NP-2307-LD.

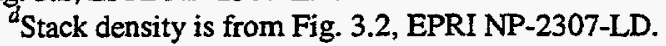

${ }^{\text {}}$ Value taken from EPRI NP-2307-LD, p. 3-3; conflicts with p. A-6 EPRI NP-240, which is quoted as 9.99 and 9.04 for $\mathrm{P} 1 / \mathrm{P} 2$ and P3/P4, respectively.

Table 3.2. Dimensional description of MOX lattice

\begin{tabular}{|c|c|c|}
\hline Dimension & English units (in.) & Metric units (cm) ${ }^{a}$ \\
\hline $\begin{array}{l}\text { Inside box corner radius (corner pin center } \\
\text { to inside of channel box) }\end{array}$ & 0.425 & 1.079 \\
\hline Box outside dimension & 5.438 & 13.813 \\
\hline Channel box metal thickness & 0.080 & 0.203 \\
\hline Pin pitch & 0.738 & 1.874 \\
\hline Narrow/narrow gap thickness & 0.374 & 0.950 \\
\hline Wide/wide gap thickness & 0.750 & 1.905 \\
\hline Pin outside radius of clad & 0.282 & 0.716 \\
\hline Pin inside radius of clad $\left(\mathrm{UO}_{2}\right)$ & 0.245 & 0.622 \\
\hline Pin inside radius of clad (MOX) & 0.250 & 0.635 \\
\hline Pellet radius $\left(\mathrm{UO}_{2}\right)$ & 0.239 & 0.607 \\
\hline Pellet radius (MOX) & 0.244 & 0.620 \\
\hline
\end{tabular}

${ }^{a}$ Original measurements were given in inches, metric units are derived. 


\subsubsection{Mixed-Oxide Fuel Isotopics}

Table 3.1 refers to two types of plutonium ( $80 \%$ fissile and $90 \%$ fissile). A description of the isotopic composition is contained in EPRI NP-3568 and is shown below in Table 3.3.

Table 3.3. Plutonium and uranium at. \% isotopics in MOX fuel

\begin{tabular}{cccccccccc}
\hline \% Fissile & ${ }^{238} \mathbf{P u}$ & ${ }^{239} \mathbf{P u}$ & ${ }^{240} \mathbf{P u}$ & ${ }^{241} \mathbf{P u}$ & ${ }^{242} \mathbf{P u}$ & ${ }^{234} \mathrm{U}$ & ${ }^{235} \mathbf{U}$ & ${ }^{236} \mathbf{U}$ & ${ }^{238} \mathbf{U}$ \\
\hline 80 & 0.25 & 75.66 & 18.49 & 4.47 & 1.13 & 0.005 & 0.72 & - & 99.28 \\
90 & 0.12 & 87.16 & 10.06 & 2.38 & 0.28 & 0.005 & 0.72 & - & 99.27 \\
\hline
\end{tabular}

\subsubsection{Adjoining Assemblies and Boundary Conditions}

A map showing the adjoining neighbors (for cycle 2) of GEB-161 is shown in Fig. 3. The requisite information for the adjoining assemblies is provided in Appendix B, even though a reflective boundary condition may be chosen for the model. The lattice dimensions (in English units) are also shown in Fig. 3. Dimensions (in English and metric units) are provided in Table 3.2. Note that Fig. 2 must be rotated 180 degrees counterclockwise to correspond to the orientation shown in Fig. 3 . Table 3.4 provides physical data for the surrounding assemblies. The pin descriptions for the fuel loading patterns of the surrounding assemblies are described in Appendix B.

Table 3.4. Fuel types for adjacent assemblies (ref: EPRI NP-240)

\begin{tabular}{ccccc}
\hline Assembly No. ${ }^{a}$ & Fuel in pins & $\begin{array}{c}\text { Assembly } \\
\text { type }\end{array}$ & $\begin{array}{c}\text { No. of Gd rods } \\
\text { (D-dished } \\
\text { U-undished) }\end{array}$ & $\begin{array}{c}\text { Cycle - avg U-235 enrichment } \\
\text { (I-initial bundle, } \\
\text { R-reload in Cycle 2), \% }\end{array}$ \\
\hline CX-0310 & $\mathrm{UO}_{2}$ & $1 \mathrm{a}$ & 3-D & $\mathrm{I}-2.12$ \\
$\mathrm{CX}-0482$ & $\mathrm{UO}_{2}$ & $2 \mathrm{a}$ & $2-\mathrm{D}$ & $\mathrm{I}-2.12$ \\
$\mathrm{CX}-0261$ & $\mathrm{UO}_{2}$ & $1 \mathrm{a}$ & 3-D & I (shuffled) - 2.12 \\
CX-0516 & $\mathrm{UO}_{2}$ & $2 \mathrm{a}$ & 2-D & $\mathrm{I}-2.12$ \\
CX-0575 & $\mathrm{UO}_{2}$ & $2 \mathrm{a}$ & 2-D & $\mathrm{I}-2.12$ \\
GEB 158-161 & $\mathrm{MOXNO}_{2}$ & 5 & 5-U & R - 2.71 \\
\hline
\end{tabular}

${ }^{a}$ See Fig. 3.

\subsubsection{Control Rods}

Control rod insertion is not modeled in any of the assemblies. With respect to GEB-161 and the cruciform rod that runs between the four MOX bundles, only a small amount of insertion was used at the very beginning of cycle 2 . For most of the cycle, this rod was withdrawn and was therefore modeled as such. Three other control rods may have influenced the local power distribution. Partial insertions of these rods occurred in the reactor. However, most of these movements were in the first half of the cycle. From approximately June 1975 until the end of cycle in January 1976, all of these rods were completely withdrawn and the power history of the reactor was generally steady (EPRI NP240). For the purposes of this benchmark, a judgment was made that these rods would not be modeled. The approach to determining the assembly power for GEB-161 (which is affected by the overall rod pattern strategy) is discussed below. 


\subsubsection{Power History Modeling for GEB-161 and Its Neighbors}

All of the neighbors for GEB-161 were inserted in the initial core and remained in place until the end of cycle 2, with the exception of CX-0261, which was shuffled from an adjoining region. All five MOX bundles were inserted at the beginning of cycle 2. The burnup of the CX assemblies (at 21 in. above the bottom of active fuel) is not currently known. Because the overall cycle 1 core average burnup was 7,239 MWd/MT (see p. A-18, EPRINP-240), this value is suggested as the burnup for adjoining assemblies prior to insertion in cycle 2 .

CX-0261 was the only assembly that was shuffled from another part of the core. Orientation changes (if they occurred) for the CX bundles are not known and were not found in the EPRI documentation.

In the analyses presented subsequently, only assembly GEB-161 was modeled with "white" boundary conditions. If one wishes to model the surrounding assemblies, then the CX bundles would need to be burned prior to insertion of the MOX bundles. Lacking data on orientations, the assembly arrangement in Fig. 3 is the recommended basis for a model.

Reference EPRI NP-2307-LD states that the bundle average exposure of the center MOX bundles was about $8300 \mathrm{MWd} / \mathrm{t}$. For GEB-161, an estimated average bundle exposure of 11,206 $\mathrm{MWd} / \mathrm{t}$ was cited in EPRI NP-214 (p. 5-12) for an elevation of $21 \mathrm{in.}$. A burnup period of 531 days (from July 21, 1974, to January 2, 1976) represents the calendar time of irradiation.

For the ORNL HELIOS analysis (further discussed in Sect. 3.2) an assembly average burnup of $11,722 \mathrm{MWd} / \mathrm{t}$ (for assembly GEB-161 at $21 \mathrm{in}$.) was used to match the measurements. This resulted in an average burnup of $11,890 \mathrm{MWd} / \mathrm{t}$ for the nine destructively examined pins (see Fig. 2). This matches the average of the quoted nine-pin burnup using the values in EPRI NP-2307-LD. If the neighboring five CX assemblies are modeled for cycle 2, for lack of better information, it is suggested that the burnup iteration be performed so that the nine MOX pins achieve a burnup of $11,890 \mathrm{MWd} / \mathrm{t}$.

\subsubsection{Thermal-hydraulic Input Parameters}

Table 3.5 shows the thermal-hydraulic input parameters for measurements taken at $21 \mathrm{in}$. above the bottom of active fuel (node 4). These parameters were selected based on saturation conditions for the rated pressure of 1035 pounds per square inch absolute (PSIA). The void fraction was taken to be 0.0 at this node (known as axial node 4 in the EPRI documentation).

Table 3.5. Thermal-hydraulic parameters for 21 in. above bottom of fuel (node 4) (ref: QUAD-CONVER)

\begin{tabular}{ccccc}
\hline $\begin{array}{c}\text { Pressure } \\
\text { (PSIA) }\end{array}$ & $\begin{array}{c}\text { Water density inside/ } \\
\text { outside assembly }\end{array}$ & $\begin{array}{c}\text { Fuel temp } \\
\text { (average) }\end{array}$ & $\begin{array}{c}\text { Water temp } \\
\text { inside assembly }\end{array}$ & $\begin{array}{c}\text { Water temp } \\
\text { outside assembly }\end{array}$ \\
\hline 1035 & $\begin{array}{c}46.1\left(\mathrm{lbm} / \mathrm{ft}^{3}\right) \\
\left(0.7375 \mathrm{~g} / \mathrm{cm}^{3}\right)\end{array}$ & $\begin{array}{c}1040^{\circ} \mathrm{F} \\
\left(560^{\circ} \mathrm{C}\right)\end{array}$ & $\begin{array}{c}547^{\circ} \mathrm{F} \\
\left(286^{\circ} \mathrm{C}\right)\end{array}$ & $\begin{array}{c}547^{\circ} \mathrm{F} \\
\left(286^{\circ} \mathrm{C}\right)\end{array}$ \\
\hline
\end{tabular}

\subsubsection{Alloy Compositions for Nuclear Analyses}

Table 3.6 shows the weight percent alloy compositions for the Zircaloy 4 channel box material and the Zircaloy-2 clad pins. A density of $6.55 \mathrm{~g} / \mathrm{cc}$ was selected for both materials. 
Table 3.6. Alloy compositions

(ref: p. A-8, EPRI NP-240)

\begin{tabular}{ccc}
\hline Metal & $\begin{array}{c}\text { Zircaloy }-2 \\
\text { (wt \%) }\end{array}$ & $\begin{array}{c}\text { Zircaloy -4 } \\
\text { (wt \%) }\end{array}$ \\
\hline $\mathrm{Zr}$ & 98.30 & 98.24 \\
$\mathrm{Fe}$ & 0.14 & 0.21 \\
$\mathrm{Sn}$ & 1.40 & 1.45 \\
$\mathrm{Ni}$ & 0.06 & - \\
$\mathrm{Cr}$ & 0.10 & 0.10 \\
\hline
\end{tabular}

\subsection{HELIOS MODEL FOR GEB-161}

The relevant input data for the HELIOS code from Sect. 3.1 (the geometry and fuel description) was used to model GEB-161. The HELIOS code uses the collision probability methodology for neutron and gamma transport for two-dimensional (2-D) geometries. HELIOS is a Scandpower, Inc., proprietary code. ORNL has a license for Version 1.4 of the code and executed the code on an IBM $\mathrm{RS} / 6000$ Model 590 . The code is used to analyze fuel assembly lattices and provides collapsed assembly cross sections as an input into other core-wide neutronics simulation codes. Thirty-eight neutron group cross-section data derived from Evaluated Nuclear Data File/B-VI supplied by Scandpower, Inc., were used in this calculation. Further information on the code is found in reference HELIOS-DOC. The HELIOS input is provided in Appendix C.

The visualization module of the HELIOS code system, ORION, produced Fig. 4 from the input data given in Appendix $\mathrm{C}$. Note that all the details of the bundle are included explicitly and that burnup-dependent parameters, such as fluxes and isotopics, are calculated for each region defined between straight or curved line segments. Multiple radial zones were included for the pins with burnable poisons $\left(\mathrm{Gd}_{2} \mathrm{O}_{3} / \mathrm{UO}_{2}\right.$ pins $)$ for a better simulation of the gradual radial burning of gadolinium. The input value for the average burnup of the 49 pins $(11,722 \mathrm{MWd} / \mathrm{t}$ obtained by iteration) yielded a value of $11,890 \mathrm{MWd} / \mathrm{t}$ for the average burnup of the nine destructively analyzed pins. This value is the average quoted burnup for the nine pins (as obtained from EPRI NP-2307 LD). The 11,722 MWd/t (average assembly burnup) HELIOS value compares well with the quoted value of $11,206 \mathrm{MWd} / \mathrm{t}$ (EPRI NP-214). Fourteen equally spaced burnup steps were computed along the 18month irradiation period. No downtime existed between steps. The input listing in Appendix C also describes a few geometric simplifications related to the fuel with respect to the clad gap and the annular MOX fuels. These gaps were not explicitly simulated in the model, and the densities of the clad and the MOX fuel were appropriately diluted. A white reflective boundary condition was imposed at the boundaries of the model on the outside of the wide and narrow water channels. A uniform fuel temperature distribution was used.

The output of the HELIOS calculations was intentionally limited because only a comparison to the available experimental data was desired. The approach generally taken was to examine the results according to the pin type: $\mathrm{MOX}$ or $\mathrm{UO}_{2}$. Much more information is available from the calculational model than is presented here. The calculated-to-measured comparisons that were performed have been organized into three sections:

1. Gadolinium analysis (isotopic at. \%) comparison for the single $\mathrm{UO}_{2} / \mathrm{Gd}_{2} \mathrm{O}_{3}$ pin that was destructively examined. 
2. Isotopic comparisons that include the following measurements:

Uranium isotopics $\left({ }^{235} \mathrm{U},{ }^{236} \mathrm{U}\right.$, and ${ }^{238} \mathrm{U} ;{ }^{234} \mathrm{U}$ measurements taken but not compared), plutonium isotopics $\left({ }^{239} \mathrm{Pu},{ }^{240} \mathrm{Pu},{ }^{241} \mathrm{Pu}\right.$, and ${ }^{242} \mathrm{Pu}$ ), and neodymium isotopics $\left({ }^{145} \mathrm{Nd}\right.$, ${ }^{146} \mathrm{Nd}$, and ${ }^{148} \mathrm{Nd}$ ). The units of the measured data were the ratios of atom densities to the initial ${ }^{238} \mathrm{U}$ atom density. Since the neodymium isotopics relate to burnup measurements, their comparisons are discussed in item 3.

Number of atoms of ${ }^{237} \mathrm{~Np},{ }^{241} \mathrm{Am}$, and ${ }^{242} \mathrm{Cm}$ per mg of initial uranium (the measurements were translated to the units quoted above).

Curium 242 and Americium 243 isotopic percentages were reported. Two values were compared: ${ }^{243} \mathrm{Am} /\left({ }^{241} \mathrm{Am}+{ }^{243} \mathrm{Am}\right)$ and ${ }^{242} \mathrm{Cm} /\left({ }^{242} \mathrm{Cm}+{ }^{243} \mathrm{Cm}+{ }^{244} \mathrm{Cm}\right)$.

3. Relative distributions of the fission product ${ }^{140} \mathrm{Ba}$ (within the nine analyzed pins) by using the normalized measurements of the ${ }^{140} \mathrm{La} 1.6 \mathrm{MeV}$ gamma. As discussed in the next section, this distribution is sensitive to the history of the irradiation (e.g., the fission rate and thus the power distribution of the pins) during the final months of the cycle. It is acknowledged that the fission rate and power distribution are distinct entities because the power distribution includes gamma heating. In this report, however, this phenomenon is ignored and the term "pin power" is used.

The total burnup values for each of the nine pins are examined for trends even though the average burnup of the nine pins is normalized in the HELIOS calculation. Neodymium atom densities will be compared in the next section.

\subsection{END-OF-CYCLE-2 MEASUREMENT INFORMATION AND HELIOS COMPARISON RESULTS}

At the end of cycle 2 , nine fuel rods including $\mathrm{UO}_{2}, \mathrm{UO}_{2}-\mathrm{PuO}_{2}$ and $\mathrm{UO}_{2}-\mathrm{Gd}_{2} \mathrm{O}_{3}$ were removed from GEB-161 (six rods were also removed from GEB-162, which is on the periphery of the core, but are not considered here). EPRI documentation of these examinations include EPRI NP-2307-LD (destructive examinations) and EPRI NP-214 (nondestructive power measurements). The destructive examinations include isotopic determinations for the isotopes of neodymium (used to obtain measured burnup), gadolinium, americium, curium, neptunium, plutonium, and uranium. The nondestructive examinations include gamma scanning measurements of the ${ }^{140} \mathrm{La}$ gammas. Power distributions are derived from the gamma scan. Comparisons between the measured data and the HELIOS calculations are presented in the following sections.

\subsubsection{Destructive Isotopic Analysis-Gadolinium Analysis in a $\mathrm{UO}_{2} \operatorname{Rod}(\mathrm{F} 6)$}

Rod F6 in GEB-161 is a $\mathrm{UO}_{2}$ rod that contains $2.5 \mathrm{wt} \%$ gadolinia. This sample was taken at approximately $21 \mathrm{in}$. from the bottom of the active fuel. Investigation of this rod was performed so that the impact on gadolinium depletion in $\mathrm{UO}_{2}$ due to the presence of nearby MOX rods could be studied. Two of the eight neighbors of rod F6 are MOX rods.

The beginning- and end-of-cycle gadolinium measurements are shown in Fig. 5. The major burnable isotopes are ${ }^{155} \mathrm{Gd}$ and ${ }^{157} \mathrm{Gd}$, which are mostly gone by the end of the cycle. Figure 6 shows the calculated (HELIOS)-to-measured comparisons for these atom percentage measurements. The center marker in this figure represents the calculated-to-measured ratio. Using the quoted measurement error (EPRI NP-2307 LD) of one sigma for the uncertainty in measurement only, a high and low marker for each calculated-to-measured ratio is also plotted. The selected set of measurements (in 
table form) are provided in Appendix D (Table D.1), along with the calculated HELIOS comparison values. It is suspected that the error bars (for ${ }^{155} \mathrm{Gd}$ and ${ }^{157} \mathrm{Gd}$ ) do not sufficiently account for the difficulty in measuring the low amounts of these isotopes that were present in the rod. Comparisons for $\mathrm{Gd}$ pins surrounded entirely by $\mathrm{UO}_{2}$ rods and gadolinium pins surrounded by more MOX rods would be useful in interpreting these results.

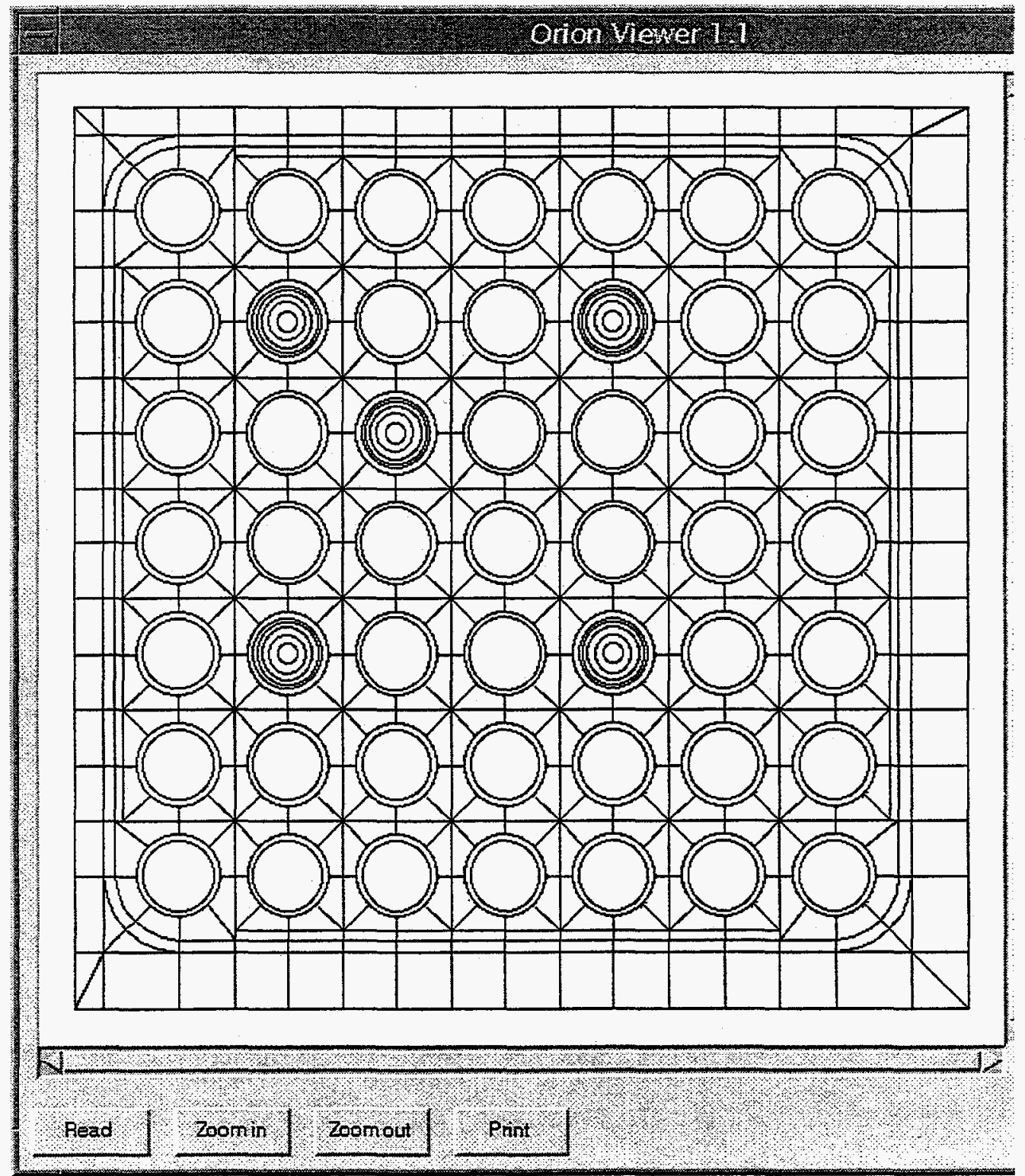

Fig. 4. HELIOS calculational model showing the calculated flux regions. 


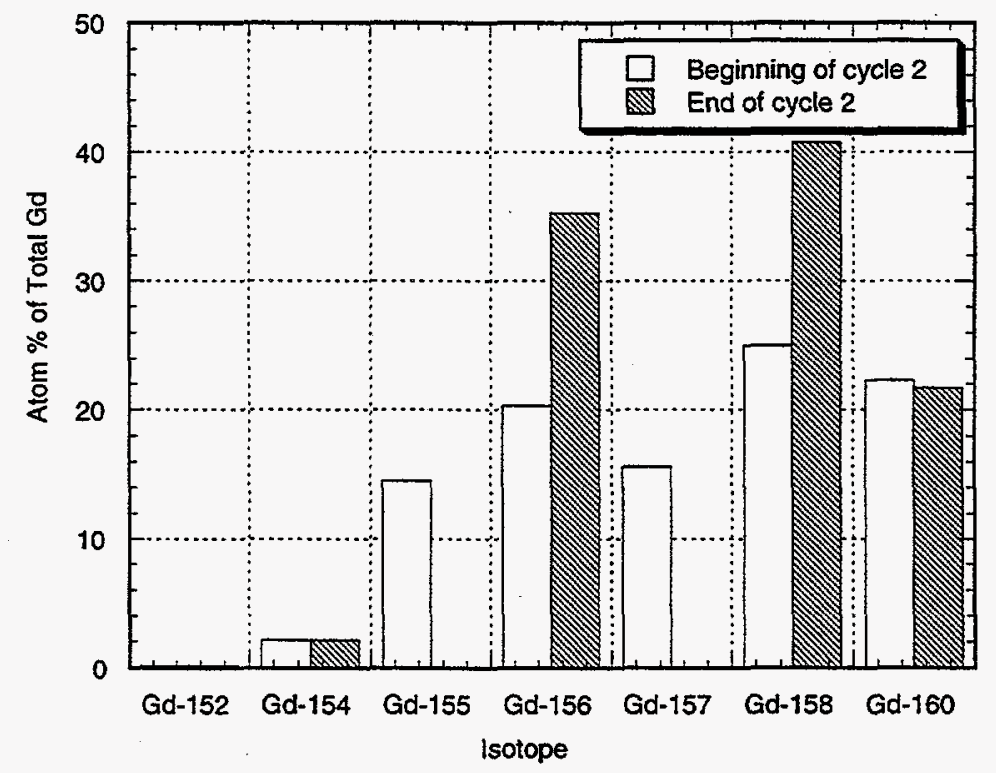

Fig. 5. Beginning- and end-of-cycle gadolinium-measured isotopic abundances.

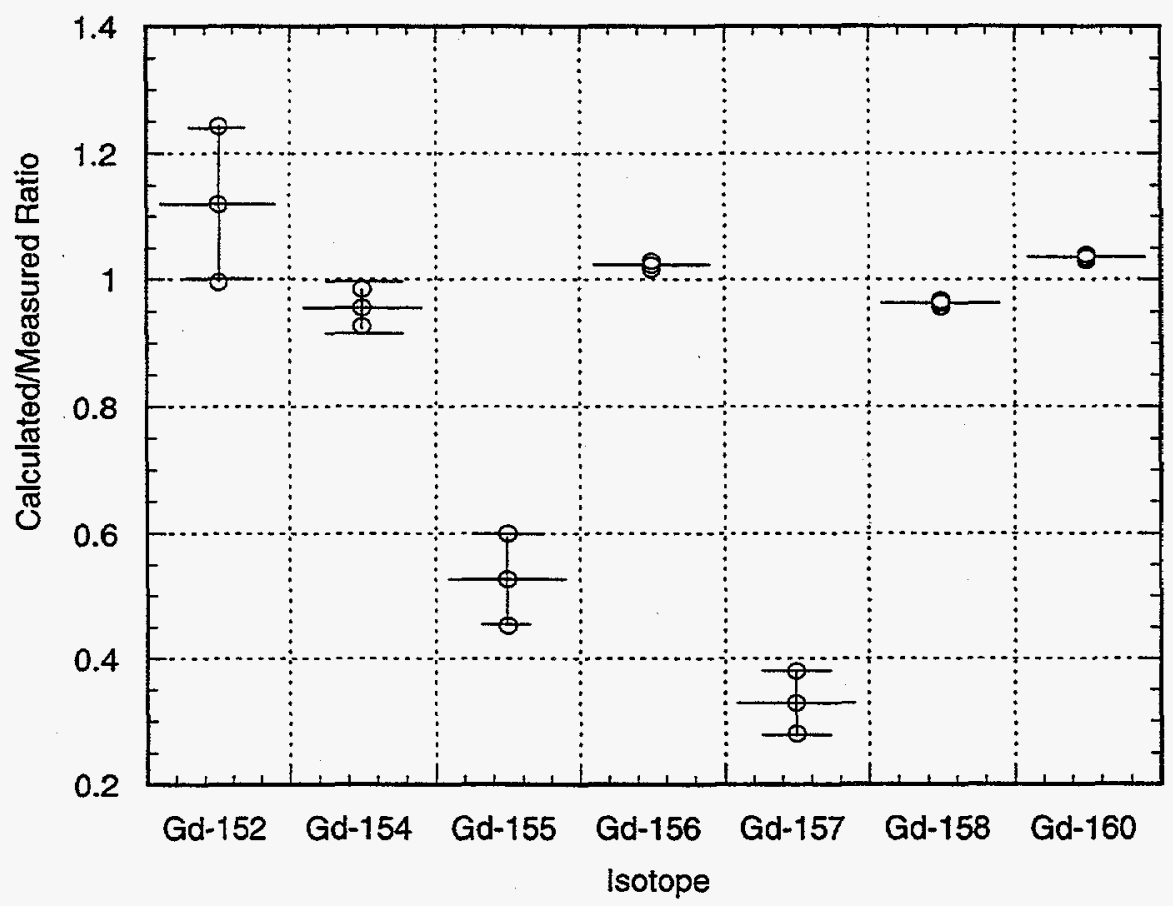

Fig. 6. Calculated-to-measured values for gadolinium in pin F6. 


\subsubsection{Destructive Isotopic Analysis-Uranium and Transuranics}

Measurements for the isotopes of uranium, neptunium, plutonium, americium, and curium were taken at 21 in. above the bottom of the active fuel. Appendix A of EPRI NP-2307-LD provides a summary of the isotopic results for both uranium- and plutonium-based fuels. Tables showing the rod . calculations, measurements, and the respective measurement uncertainties for each pin are listed in the tables in Appendix $D$ (for all nine rods and the average values). For isotope-by-isotope comparisons, the average of the four $\mathrm{MOX}$ rods and the average of the four $\mathrm{UO}_{2}$ rods were computed. The grouping of the rods in this manner was done so that any specific $\mathrm{MOX}$ - and $\mathrm{UO}_{2}$ - related trends might be observed. The quoted calculated-to-measured ratio ( $\mathrm{C} / \mathrm{M}$ ratio) refers to calculated and measured values of the atom density of the isotope divided by the initial ${ }^{238} \mathrm{U}$ atom density (a constant).

The following box plots in this section take into account the quoted experimental uncertainty in the following manner. For the four rods (either a $\mathrm{MOX}$ or $\mathrm{UO}_{2}$ grouping as noted on the $\mathrm{x}$-axis), the top line of the box represents the highest calculated-to-measured ratio of the four rods. Above the top of the box is an error bar. This error bar is simply the "one sigma" measurement error applied to the highest (of the four) calculated-to-measured ratios. Generally near the middle of the box is a line with a circular marker, which indicates the simple arithmetic average of the four calculated-to-measured ratios $\left(\mathrm{MOX}\right.$ or $\left.\mathrm{UO}_{2}\right)$ for that isotope. The lower line of the box represents the lowest of the four calculated-to-measured ratios. All four calculated-to-measured ratios fall somewhere inside the box. The lower error bar, extending from the bottom of the box, is simply the lowest of the four ratios minus the "one sigma" measurement error. This method of representation is not the standard approach for box plots. However, a glance at the box and the measurement error bars facilitates a better visual comparison of the calculated-to-measured ratios among pin types and provides an indication of the measurement error impact.

Figure 7 shows the box plot for the uranium and ${ }^{237} \mathrm{~Np}$ isotopes. Figures 8 and 9 show similar plots for the plutonium isotopes and the americium/curium isotopes. The ${ }^{237} \mathrm{~Np}$, ${ }^{241} \mathrm{Am}$, and ${ }^{242} \mathrm{Cm}$ measurements were quoted in EPRI NP-2307 LD as the number density per milligram of initial uranium. These measurements were converted to units of atom density divided by the initial ${ }^{238} \mathrm{U}$ atom density. For the isotope ${ }^{243} \mathrm{Am}$, measured isotopic percentages for the americium (e.g., the split in atom percentages for ${ }^{241} \mathrm{Am}$ and ${ }^{243} \mathrm{Am}$ ) isotopes were multiplied by the measured amounts of ${ }^{241} \mathrm{Am}$ to obtain a measured value. The same technique was used to obtain the sum of the isotopes of ${ }^{243} \mathrm{Cm}$ and ${ }^{244} \mathrm{Cm}$. For these two cases, the measured error for these isotopes was the combined measurement error of the ${ }^{242} \mathrm{Cm}$ (or ${ }^{241} \mathrm{Am}$ ) and the measurement error associated with the isotopic percentage measurement, resulting in an error that is the square root of the sum of the squares of the respective errors. The quoted measurement uncertainty in the americium for the $\mathrm{UO}_{2}$ fuels was very high (hence the arrows on this figure), precluding the possibility of a reasonable comparison.

The agreement among the uranium isotopes and the calculations is generally quite good for both types of fuel rods. However, the ${ }^{236} \mathrm{U} \mathrm{C} / \mathrm{M}$ ratios in the $\mathrm{UO}_{2}$ pins are noticably low. With the possible exception of ${ }^{237} \mathrm{~Np}$ (which has a large spread in the values due to an $18 \%$ measurement error), the results show that the plutonium and uranium isotopes are generally predicted better in the MOX rods than the $\mathrm{UO}_{2}$ rods. For the plutonium isotopes this could be due to the known values of these isotopes prior to the beginning of the cycle in combination with the low burnup. For these (plutonium) isotopes, the measured value is generally higher than the calculated value (e.g., C/M ratio $<1$, especially in the uranium fueled rods.

Even though the uncertainties are high for americium and curium $(-30 \%$ and $\sim 12 \%$ for $\mathrm{MOX}$ rods), the measured values are consistently higher than the calculated values (e.g., $\mathrm{C} / \mathrm{M}$ ratio $<1$ ). This situation is true for both $\mathrm{MOX}$ and $\mathrm{UO}_{2}$ rods, especially for the curium isotopes. For the MOX rods, the low C/M ratio of ${ }^{242} \mathrm{Cm}$ may be due to the low ${ }^{241} \mathrm{Am} \mathrm{C} / \mathrm{M}$ ratio. This is due to the fact that ${ }^{241} \mathrm{Am}$ is in the transmutation path between ${ }^{241} \mathrm{Pu}$ and ${ }^{242} \mathrm{Cm} .{ }^{243} \mathrm{Am}$ is in the transmutation path for 
the production of ${ }^{244} \mathrm{Cm}$ and ${ }^{243} \mathrm{Cm}$. As Fig. 9 shows for both $\mathrm{MOX}$ and $\mathrm{UO}_{2}$ rods, the $\mathrm{C} / \mathrm{M}$ ratios are about the same for ${ }^{243} \mathrm{Am}$ as they are for the sum of ${ }^{243} \mathrm{Cm}$ and ${ }^{244} \mathrm{Cm}$.

In general, if one looks at the $\mathrm{C} / \mathrm{M}$ ratios of isotopes as a function of atomic-weight (uranium through curium), a trend towards lower $\mathrm{C} / \mathrm{M}$ ratios is seen for the heavier isotopes. Other benchmark comparisons are needed to see if this trend is valid for higher burnups.

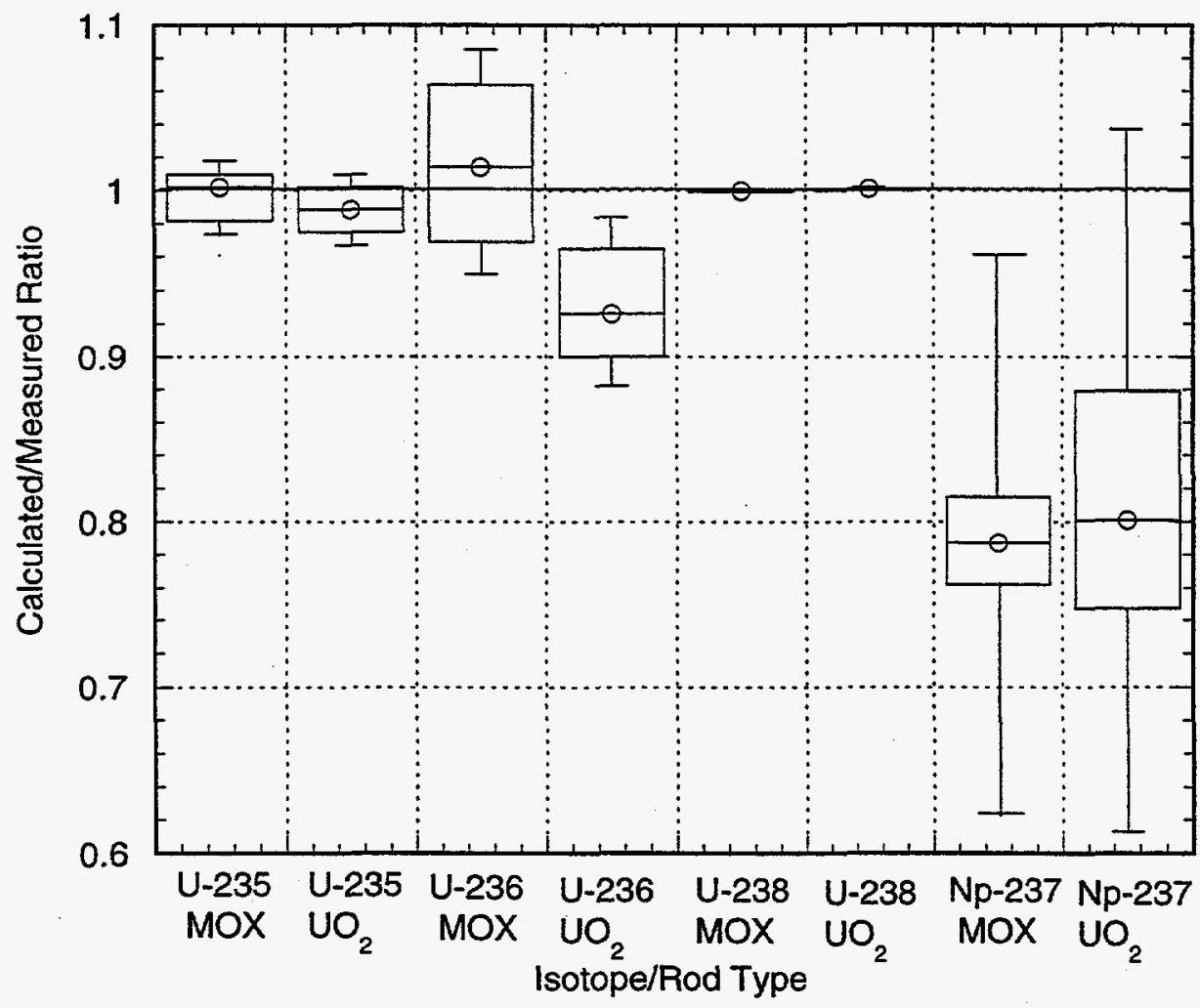

Fig. 7. Calculated (HELIOS)-to-measured comparisons (four rod representations for MOX and $\mathrm{UO}_{2}$ ) for the uranium isotopes and ${ }^{237} \mathrm{~Np}$. 


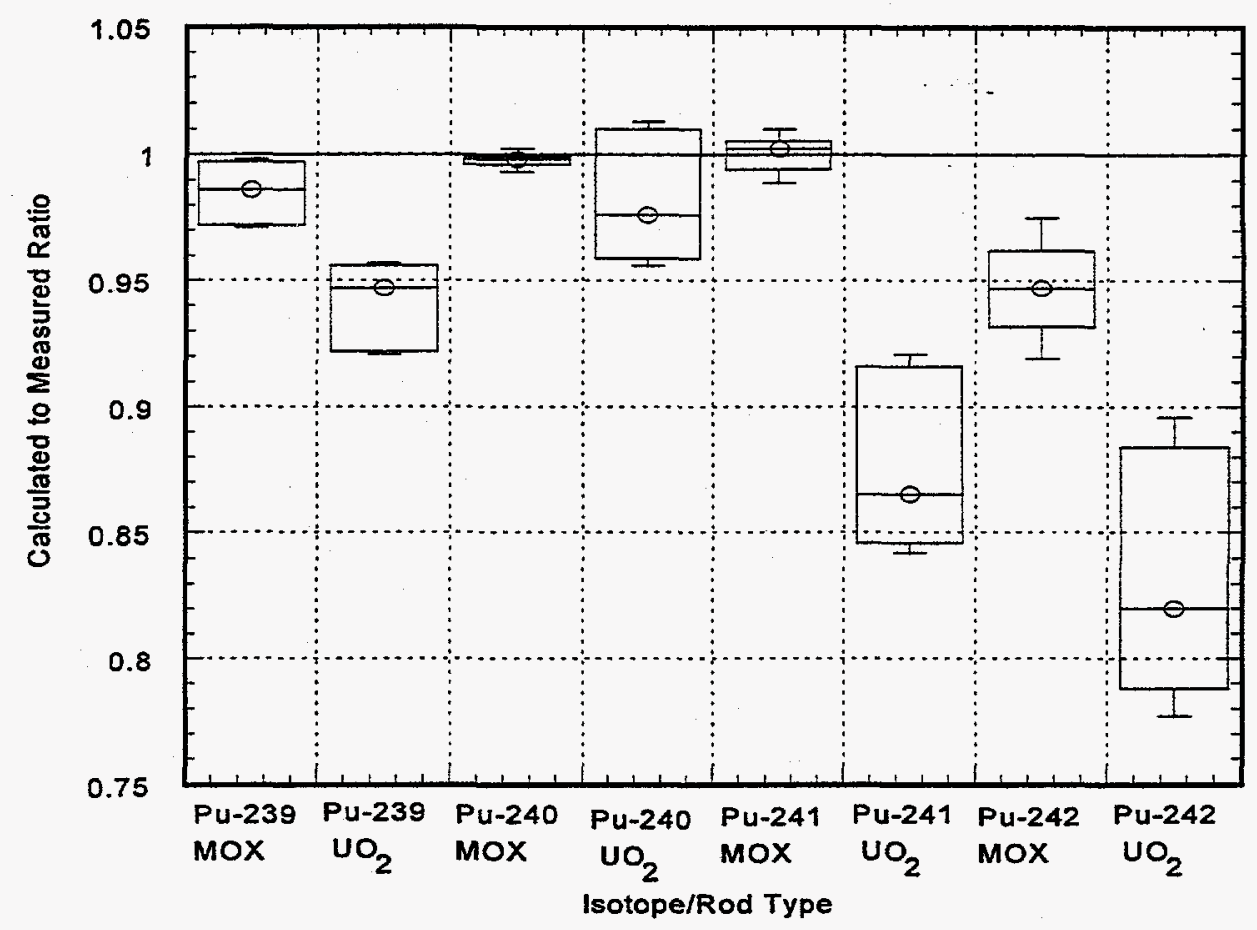

Fig. 8. Calculated (HELIOS)-to-measured comparisons (four rod representations for MOX and $\mathrm{UO}_{2}$ ) for the plutonium isotopes.

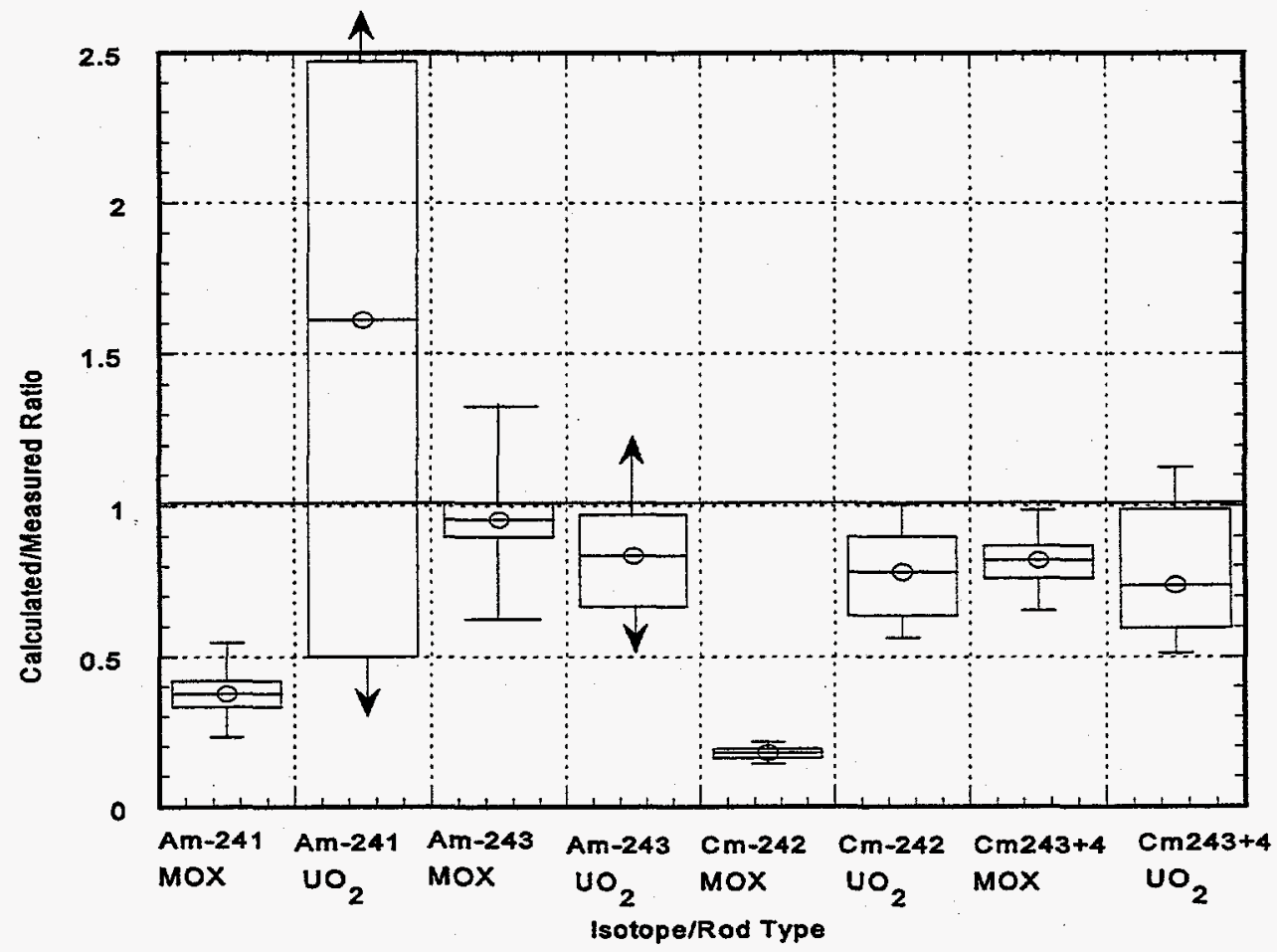

Fig. 9. Calculated (HELIOS)-to-measured comparisons (four rod representations for MOX and $\mathrm{UO}_{2}$ ) for the americium and curium isotopes. 
Relative isotopic measurements were performed for the ${ }^{242} \mathrm{Cm}$ and ${ }^{243} \mathrm{Am}$. The ${ }^{242} \mathrm{Cm}$ atom \% comparison is the ${ }^{242} \mathrm{Cm}$ divided by the sum of ${ }^{242} \mathrm{Cm} ;{ }^{243} \mathrm{Cm}$, and ${ }^{244} \mathrm{Cm}$ (calculated and measured). The ${ }^{243} \mathrm{Am}$ comparison is the ${ }^{243} \mathrm{Am}$ divided by the sum of ${ }^{241} \mathrm{Am}$ and ${ }^{243} \mathrm{Am}$ (calculated and measured). ${ }^{242}$ Am was measured, but not compared, due to its short half-life and low quantities. The calculated-to-measured comparisons are shown in Fig. 10. The comparisons show that better agreement was generally attained for the $\mathrm{UO}_{2}$ rods. However, the spreads in the calculated-tomeasured ratios and the uncertainites in the ${ }^{243} \mathrm{Am}$ concentrations are quite large.

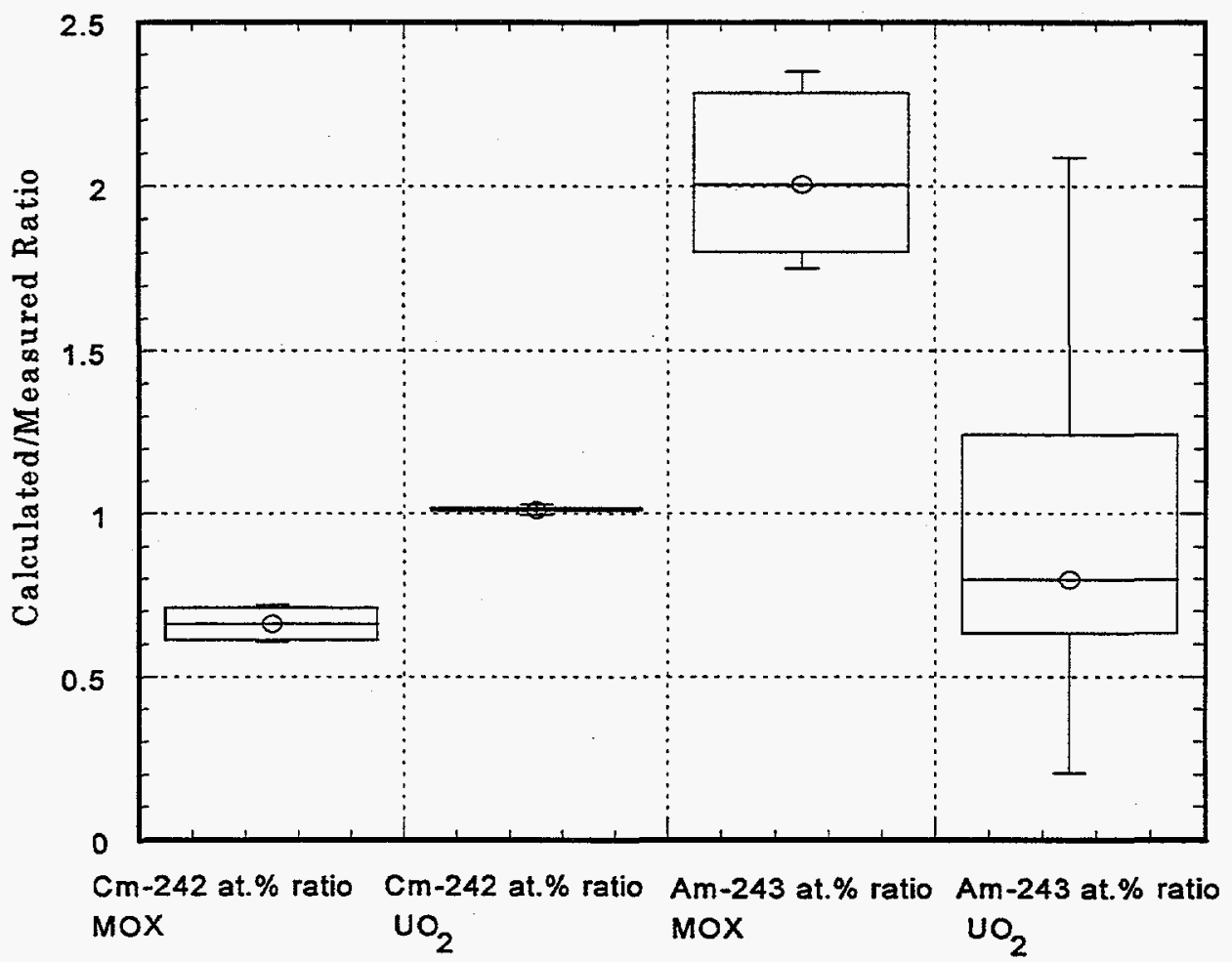

Isotope/Rod Type

Fig. 10. Calculated (HELIOS)-to-measured relative isotopic ratio comparisons (four rod representations for $\mathrm{MOX}$ and $\mathrm{UO}_{2}$ ) for the americium and curium isotopes.

\subsubsection{Power and Burnup Comparisons}

Following the end-of-cycle 2 at Quad Cities, a large number of gamma scans were conducted for the purpose of obtaining benchmark-quality, power distribution data. This procedure was done by scanning the rod or bundle for the ${ }^{140} \mathrm{La} 1.6 \mathrm{MeV}$ gamma and normalizing the data to obtain relative power distributions. Whole bundles were scanned, as were the nine rods that were subjected to destructive examination. The details of the campaign and the overall program objectives are documented in EPRI NP-214.

The actual measurements consist of ${ }^{140} \mathrm{La}$ gamma-intensity count rates. ${ }^{140} \mathrm{La}$ is marginally produced as a fission product and it decays with a half-life of approximately $40 \mathrm{~h}$. Its main source is through the decay of its parent, ${ }^{140} \mathrm{Ba}$. ${ }^{140} \mathrm{Ba}$ has a 12.8 -d half-life. The ${ }^{140} \mathrm{Ba}$ distribution in irradiated fuel is proportional to the integrated power history of the core obtained from the last several months of power operation. If one plots the atom density ratio of ${ }^{140} \mathrm{La} /{ }^{140} \mathrm{Ba}$ as a function of time after 
shutdown, a constant value of about 0.15 is obtained at approximately 10 days after shutdown (see Fig. 6.1 of EPRI NP-214). Thus, a measurement of the ${ }^{140} \mathrm{La}$ at this time is an indication of the ${ }^{140} \mathrm{Ba}$ content. Note that measured ${ }^{140} \mathrm{La}$ intensities are only useful for obtaining relative or normalized power distributions covering the last couple of months of power operation.

The barium inventories in the nine rods at the end of cycle 2 were extracted from the HELIOS code and normalized. The calculated and measured values for each rod are provided in Fig. 11. Figure 12 shows the percentage difference $[(C / M)-1]$ in the pin powers that were measured by gamma scanning and the HELIOS end of cycle calculated values for the assembly. Pin burnup percentage comparisons are also shown in this figure. The measured pin burnups are the quoted burnups from EPRI NP-2307-LD. These values are compared with the HELIOS values at the end of cycle 2 .

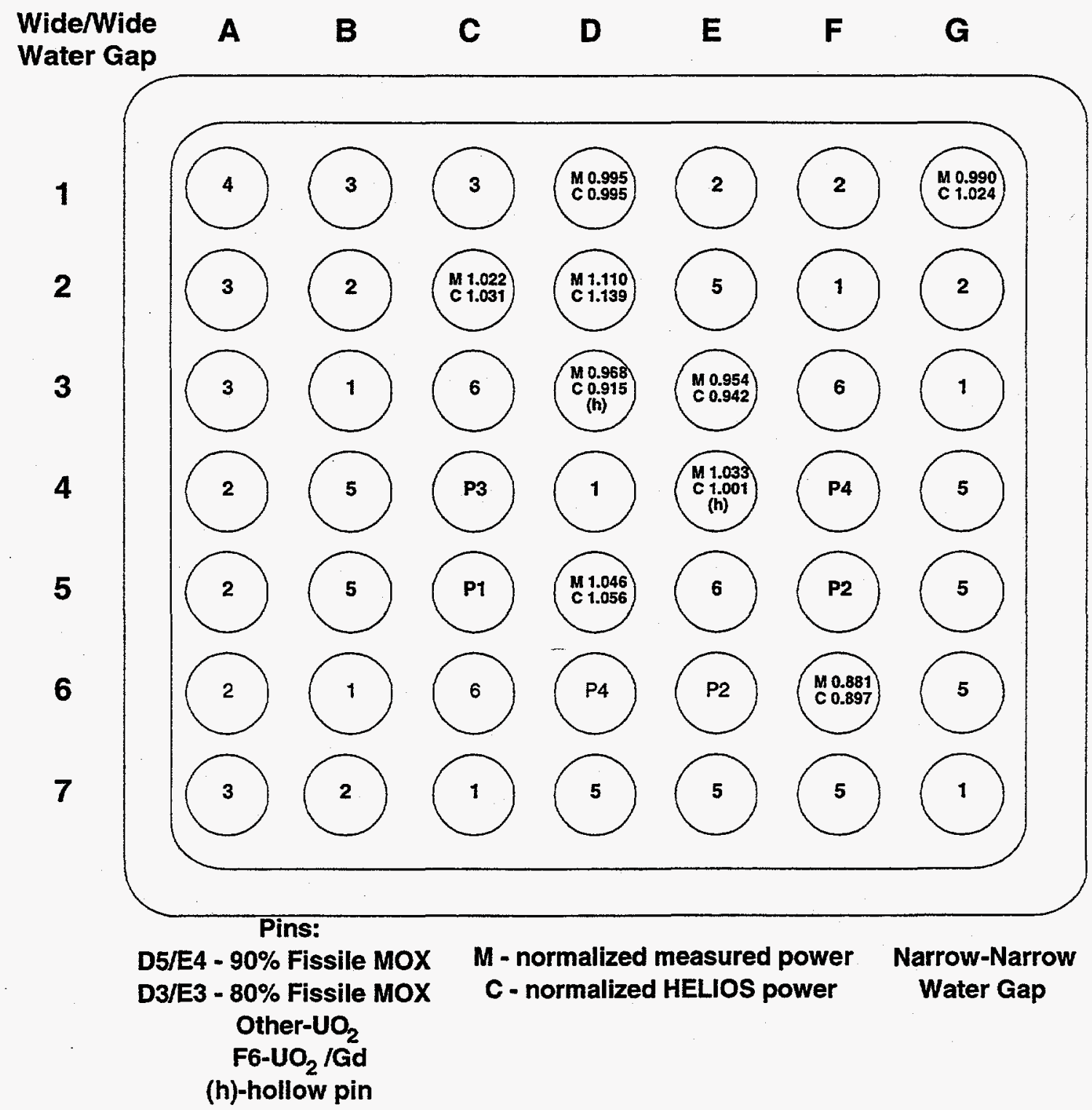

Fig. 11. Measured and HELIOS-calculated pin powers. 


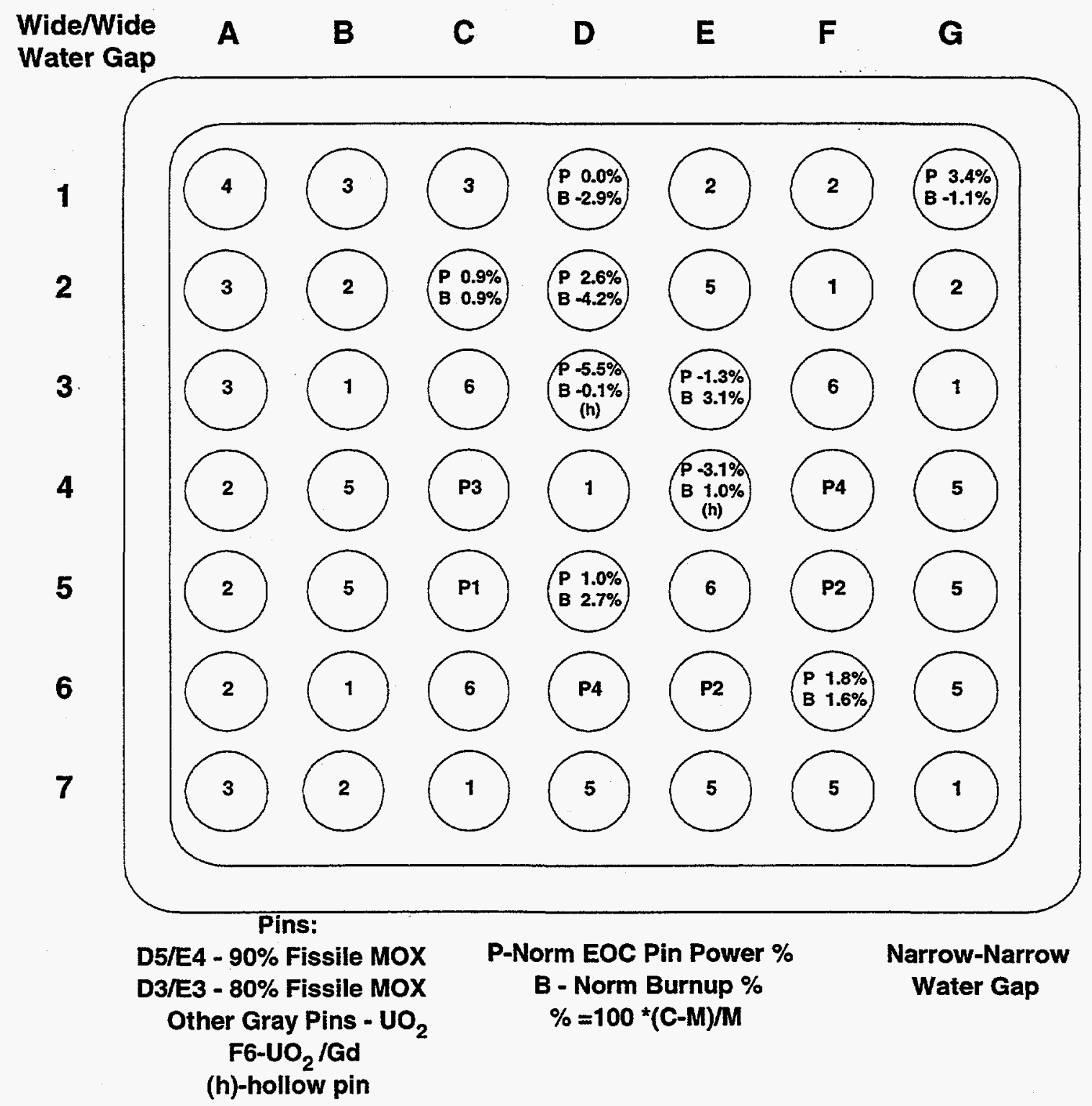

Fig. 12. GEB-161 pin power and burnup comparisons. 
Figure 13 shows a box plot of the neodymium isotopics, the pin powers, and the pin burnups. As was the case in the previous plots, the box values for the neodymium isotopes account for the quoted uncertainties. In all cases, the C/M ratios were slightly less than 1, but generally within the measurement uncertainty and tightly clustered. The neodymium values suggest that the burnup input into HELIOS should perhaps be higher by a couple of percent. Note that the HELIOS model was burned to the average reported "measured" burnup (which likely comes from a GE calculated curve for neodymium vs burnup). The model was not normalized to the values of neodymium in the pins. The difference is small.

The pin burnups reported in Fig. 13 represent a single average value. No uncertainty box for these two values can be derived. However, there are four different values that make up the average value.

Figure 13 shows that the average of the MOX pin powers has a $\mathrm{C} / \mathrm{M}$ less than 1 , and the $\mathrm{UO}_{2}$ pins have a $\mathrm{C} / \mathrm{M}$ greater than 1 . Unity is within the uncertainty (taken as $1.7 \%$ for pin power measurements) for both sets of pin power data. The box plot does suggest that the MOX pins are operating at a higher power than the calculated values (for the last couple of months of the cycle), but not by an amount that is significantly outside the uncertainty of "one sigma" of the measurement.

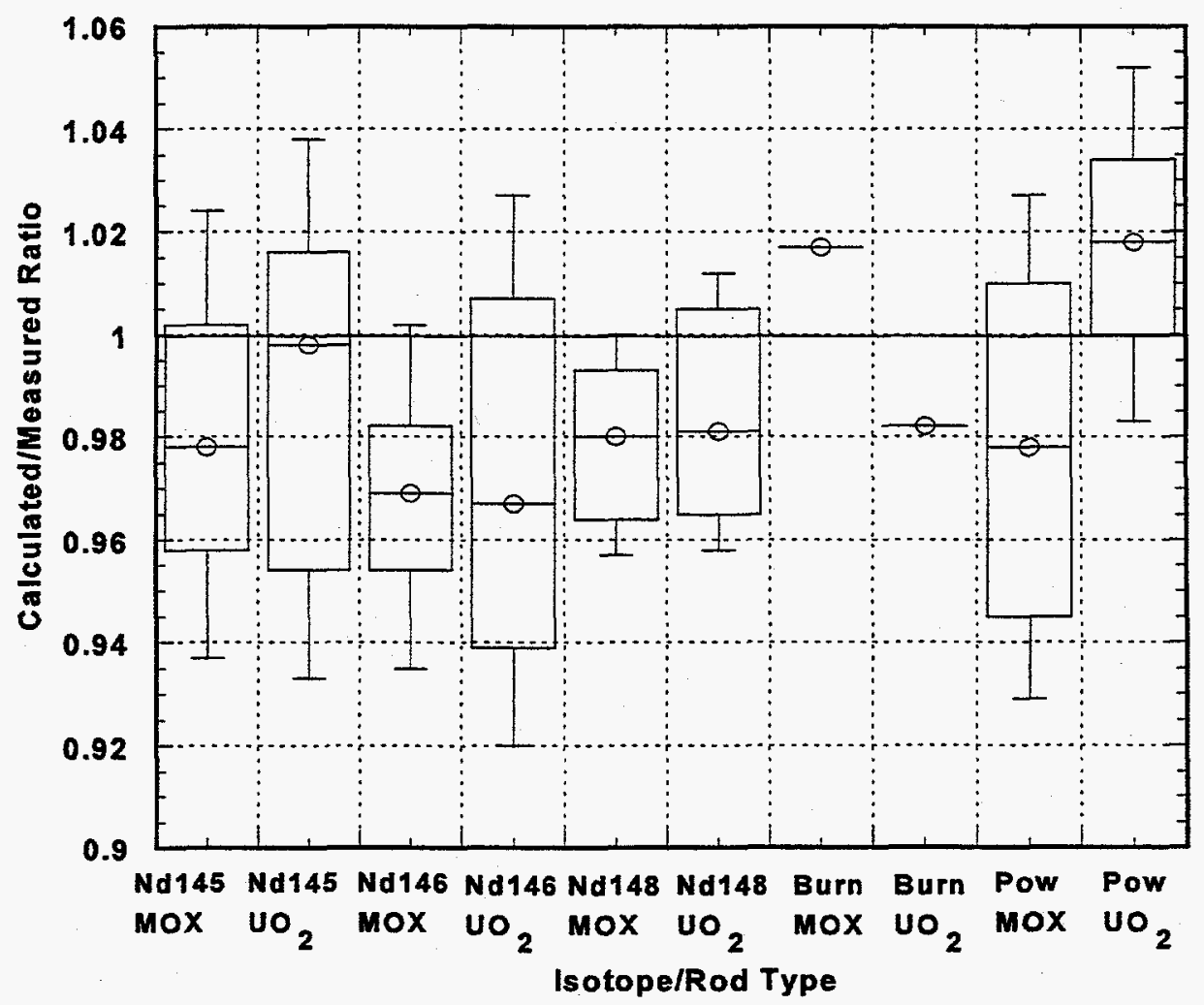

Fig. 13. GEB-161 MOX and $\mathrm{UO}_{2}$ HELIOS calculated-to-measured ratios for neodymium, pin powers and burnup. 


\subsection{SCALE AND HELIOS COMPARISONS FOR SINGLE MOX AND UO RODS $_{2}$}

The SCALE system provides a standard method for analyzing the isotopics in spent fuel (Reference SCALE-DOC). In the SCALE system, the SAS2H control module provides an analysis sequence for determining a number of spent fuel characteristics, including nuclide inventories. The neutronics methodology in this sequence is based on a one-dimensional (1-D) neutron transport calculation. Thus, no measured pin power comparisons between SCALE and HELIOS [which is two dimensional (2-D)] are feasible. However, since SAS2(H) has been used for fuel depletion and decay analyses, isotope comparisons can be performed between measurements, HELIOS and the SCALE calculations for single rods.

The input information in Sect. 3.1 was used as an input into the SAS2 sequence. In both cases an infinite surrounding array of like pins was modeled. A single MOX rod (pin D5, a 90\% fissile rod), and a single $\mathrm{UO}_{2}$ rod (pin $\mathrm{C} 2,2.56 \%$ enrichment) were chosen for the comparison. Each rod was irradiated to its reported measured burnup which is $12,500 \mathrm{MWd} / \mathrm{t}$ for the MOX pin and 11,450 $\mathrm{MWd} / \mathrm{t}$ for the $\mathrm{UO}_{2}$ pin. Appendix E contains a listing of the SCALE (Version 4.3) input decks for both rods.

Calculated-to-measured ratios are shown for the MOX rod in Fig. 14 and the $\mathrm{UO}_{2}$ rod in Fig. 15. The results show that for almost all isotopes, the SCALE method predicts higher values than the HELIOS code. 


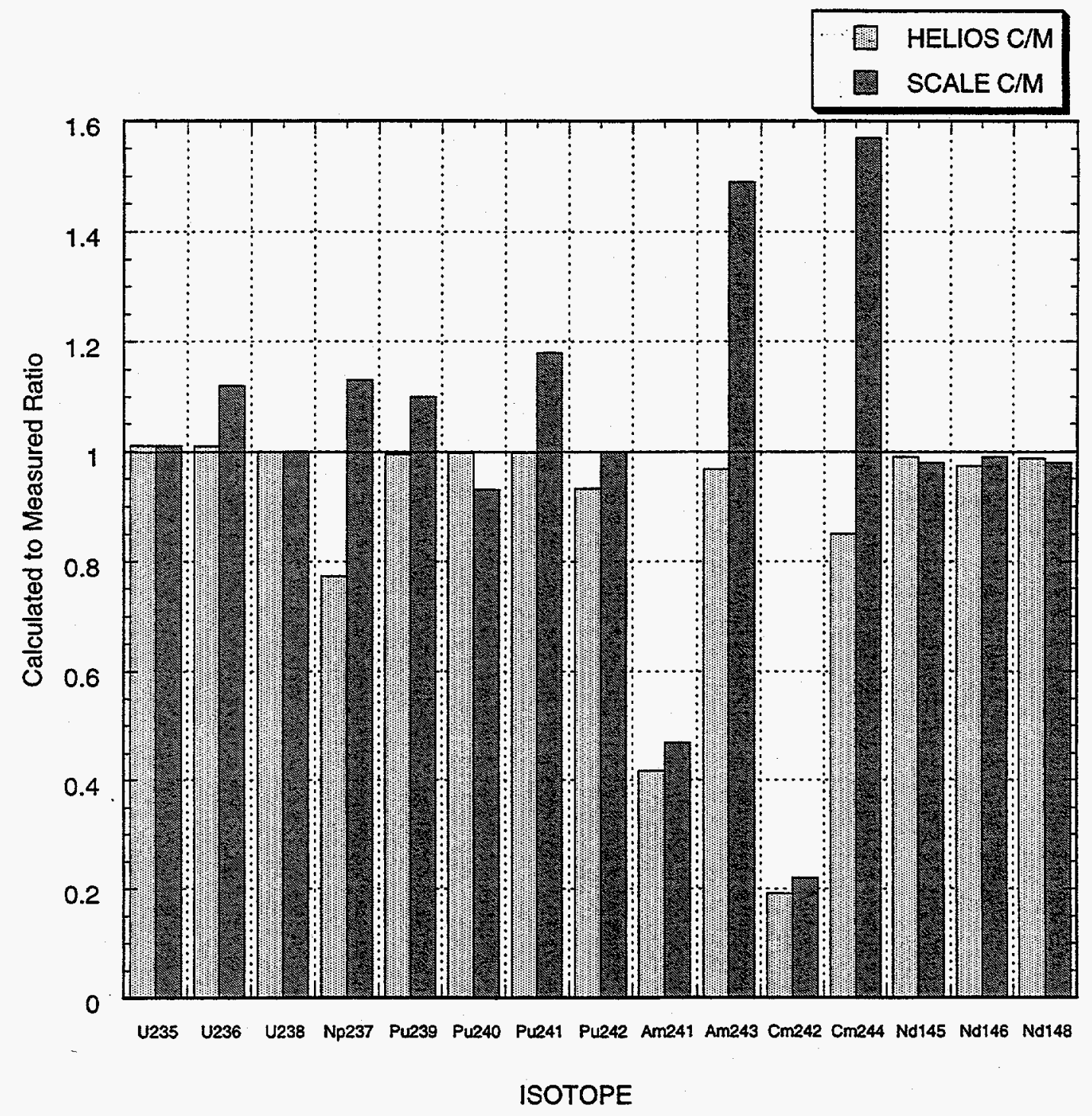

Fig. 14. Calculated-to-measured ratios (SCALE and HELIOS) for GEB-161 MOX pin D5. 


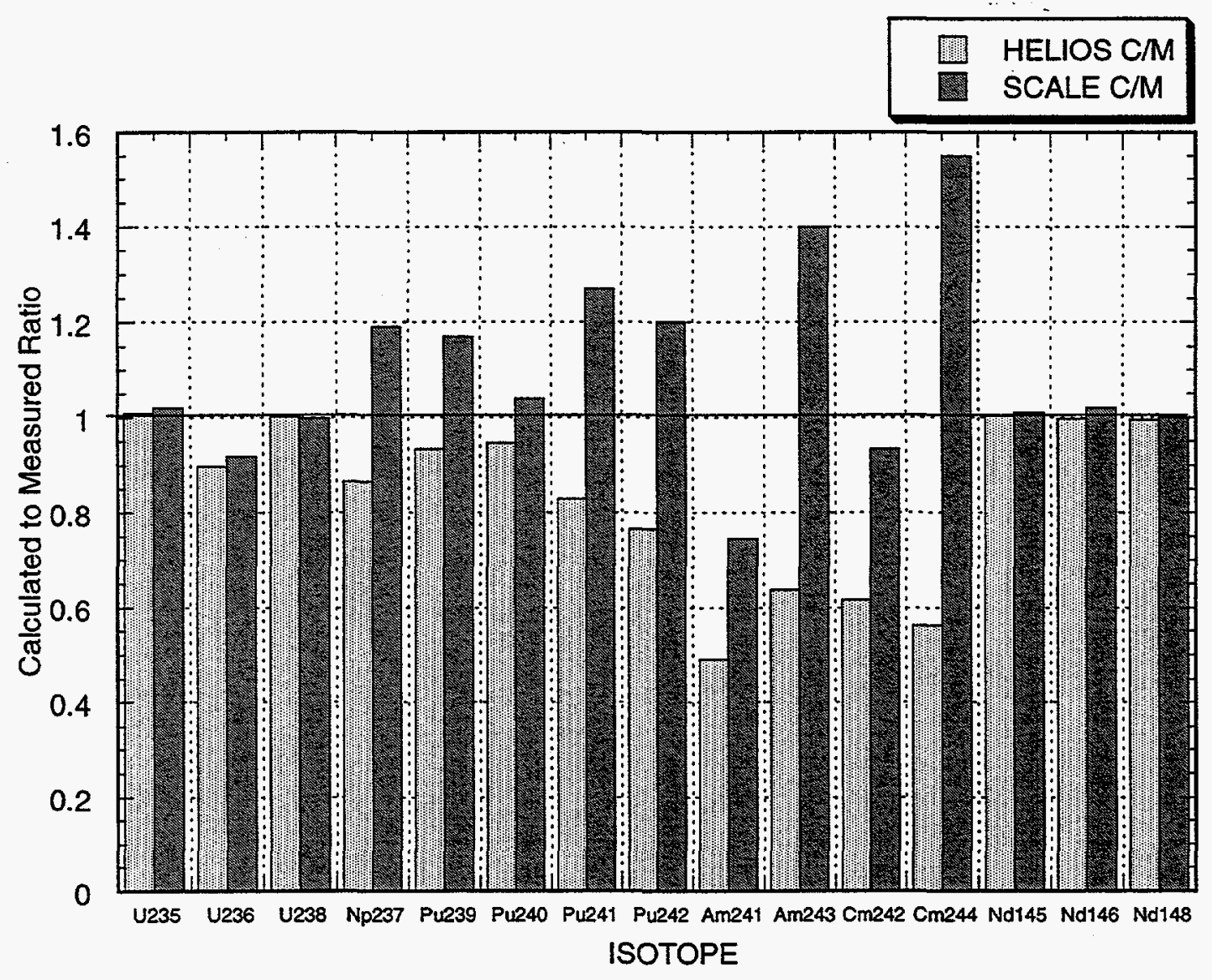

Fig. 15. Calculated-to-measured ratios (SCALE and HELIOS) for GEB-161 UO $\mathrm{UO}_{2}$ pin $\mathrm{C} 2$. 


\subsection{OPTIONS FOR ADDITIONAL BENCHMARK CALCULATIONS}

The configuration that was used for this benchmark was selected based on the ease of obtaining the input data and the availability of documented MOX pin measurements. Once the 2-D model has been constructed for the assembly, other modeling opportunities readily present themselves.

Several options are available for future benchmarks. These options are rated below (the first option being the "most desirable") according to a qualitative judgement level of additional effort (which includes obtaining additional data) that is estimated to be required. The option of using the SCALE system to model some individual pins is not included in this list, but would also constitute a useful benchmarking exercise.

1. Perform analysis of GEB-162 (peripheral bundle) at 21 in. above bottom of active core. The same assembly model can be used and modified to obtain comparisons with the peripheral MOX bundle. This bundle is shown below in Fig. 16. EPRI NP-2307-LD quotes a calculated exposure of $2700 \mathrm{MWd} / \mathrm{t}$ for this bundle. The same (as GEB-161) measured information is available for the six rods that were examined. In addition, approximately 40 rods were scanned, producing a large array of measured rod-to-rod planar distribution powers. Examination of the measurements shows that there is a wider variation in the pin power distribution, consistent with the presence of a core/reflector interface. This comparison would seem to be of interest due to more heterogeneity, the presence of a nearby reflector, and the fact that the nearby gadolinia pin (pin number 5 that is shaded) has not been completely depleted.

2. Perform analysis of GEB-161 and GEB-162 at upper axial locations. If a method for estimating the void fraction at higher locations is obtained, then further analysis on the upper samples can be conducted. In addition to the same comparisons (burnup, transuranics, and power distributions) that were conducted here, more information on gadolium burnout can be obtained. Gadolinium radial distributions would become available for rod F6 at nodes 6 and 8 (corresponding to $93.2 \mathrm{in}$. above bottom (5470 MWd/t) and $129.2 \mathrm{in}$. above bottom (3550 $\mathrm{MWd} / \mathrm{t}$ ), respectively). According to autoradiographs (and the neodymium values), however, the burnup is assymetric. This could have been due to the two nearby $90 \%$ MOX rods. This comparison would speak to any concerns about MOX spectrum changes that might result in changes in burnable poison behavior of nearby pins.

3. Perform axial and radial power bundle benchmarks of MOX bundles. If the axial void fraction history of the MOX bundles could be found or calculated, then a comparison with the end of cycle assembly's axial power profile (normalized) and additional radial power profile comparisons could be performed. Measurements are available for the end of cycle 2 (gamma scan used in this analysis), the end of cycle 3 (EPRI NP-2302-LD), and the end of cycle 4 (NEDC-25492). The full extent of these measurements has not been investigated. Cycle 3 is interesting in that a partial rod insertion would have to be modeled for this cycle. Cycle 4 measurements may be considered to be GE proprietary data. An axial diffusion theory code or some other multidimensional methodology would need to be employed.

4. Perform an analysis of MOX rod VP-0017 and high-burnup MOX rods. At the end of cycle 5 , a significant portion of the MOX rods were removed. EPRI NP-3568 states that an average rod burnup of $35 \mathrm{GWd} / \mathrm{t}$ had been achieved by a solid, $90 \%$ fissile MOX rod (which is identified as VP-0017). Its hollow counterpart had achieved $31.03 \mathrm{GWd} / \mathrm{t}$. This average is for a collection of five rods that were removed at the end of cycle 5 . These rods were gamma scanned for power and the ${ }^{137} \mathrm{Cs}$ distribution. They were then subjected to fission gas measurements. The total history of rod VP-0017 has not been located in the literature. However, if this information were 
available and rod VP-0017 was found and subjected to nondestructive measurement, a highburnup benchmark exercise could possibly be conducted. Depending on the objective, either axial comparisons or radial comparisons could potentially be performed. An axial diffusion code or some other multidimensional methodology would need to be employed. If total fuel performance (such as fission gas release models) measurements are to be compared (even though the rod was fabricated in the 1970s), then this rod would be of interest because fission gas measurements were taken.

\section{REFLECTOR}

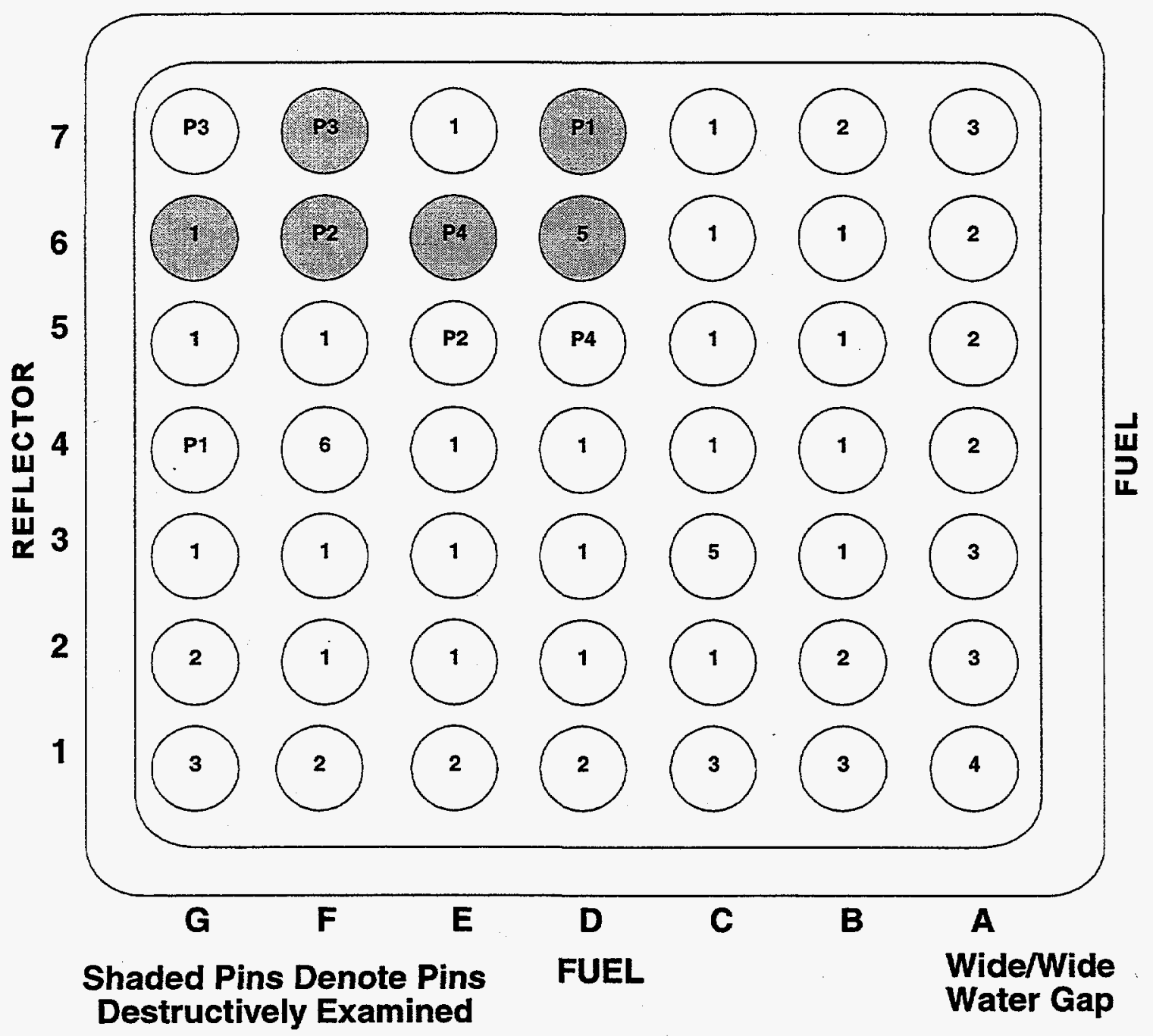

Fig. 16. GEB-162. Peripheral MOX assembly. 


\section{CONCLUSIONS}

This benchmarking effort provided valuable assembly-level comparisons for a MOX assembly (including $\mathrm{UO}_{2}$ pins) under reactor conditions. However, major conclusions concerning the neutronics performance of high-fissile MOX fuel can only be made after consideration of additional benchmark-quality data for higher burnup MOX fuel. The experience gained from this effort is summarized below.

1. For MOX rods, HELIOS models the chains for the isotopes of uranium and plutonium (MOX fuel rods in a $\mathrm{UO}_{2}$ matrix) reasonably well when compared with measured data at approximately $12,000 \mathrm{MWd} / \mathrm{t}$. However, as isotopes are transmuted up the chain, uncertainties in the measurement and the calculational difficulty (e.g., the calculated transmutation of isotopes) probably combine to make the comparison more uncertain. Indications are that the amounts of heavier actinides are underpredicted. This factor is important when consideration is given to the curium isotopes, because these neutron sources may be an important factor in the shielding analysis for spent MOX fuel.

2. The nondestructive pin power measurements are in good agreement (e.g., within the measurement uncertainty) with the calculated HELIOS values. However, there are indications that the MOX pins are runnning at slightly higher pin powers than the HELIOS-calculated power. The reverse is true for the $\mathrm{UO}_{2}$ pins. The sole measurement on the gadolinia/ $\mathrm{UO}_{2}$ pin revealed that the gadolinium (155 and 157 isotopes) was essentially depleted. However, the power measurement of this pin was very comparable to the calculated value (suggesting that the gadolinium burnup was modeled accurately).

3. The burnup measurements and HELIOS calculations are fairly consistent (within about 2\%) with respect to $\mathrm{MOX}$ rods and $\mathrm{UO}_{2}$ rods. A comparison reveals that for the MOX rods, a higher calculated total burnup ( $\mathrm{MWd} / \mathrm{t}$ ) was found as compared with the measurement. For $\mathrm{UO}_{2}$ rods, the measured burnup was higher than the calculated burnup.

4. The analysis presented here provides a reasonable starting point and a necessary first step towards the validation of neutronics methods for high-fissile MOX fuel. A review of the Quad Cities data suggests that more benchmark efforts (as described in Sect. 3.4) should be carried out on the reported measurements (that are available in the EPRI reports). It is expected that additional benchmarking may provide better information on the depletion of gadolinium (in $\mathrm{UO}_{2}$ pins) in a MOX-influenced spectrum. More isotopic data would be obtained at different burnups. Another set of power distribution data would be obtained in these exercises, and it would be interesting to know if the findings at different burnups are similar to the findings in this effort. It is thought that the benchmarking efforts will be informative, regardless of which technology (PWR or BWR) is selected for the disposition of plutonium.

5. A reason for performing the benchmarking exercise on the Quad Cities irradiation is that the fissile blends are higher than reactor grade and quite close to weapons-grade plutonium isotopics. Such measurements are rare. With respect to high-burnup Quad Cities MOX fuel (which is thought not to have undergone destructive examination) which may be available, it may be prudent to first investigate results obtained from European experimental programs, given the expense associated with having to perform additional destructive examinations. If European experience is not available, the Quad Cities MOX rods (especially the $90 \%$ fissile rods) may be the only source of information to quantify differences in key neutronics parameters between high-fissile plutonium systems and the well-characterized use of reactor-grade plutonium. 



\section{REFERENCES}

1. ORNL/MD/LTR 40. "Survey of Worldwide Light Water Reactor Experience with Mixed Uranium-Plutonium Oxide Fuel, Draft Letter Report," October 11, 1995.

2. EPRI NP-3568. "Quad Cities Nuclear and Fuel Performance Measurement," EPRI NP-3568, Electric Power Research Institute, prepared by General Electric Company (July 1984).

3. EPRI NP-240. "Core Design and Operating Data for Quad Cities 1 Cycle 2," EPRI NP-240, Electric Power Research Institute, prepared by General Electric Company (November 1976).

4. EPRI NP-2307-LD. "Burnup and Transuranium Element Composition in Irradiated $\mathrm{UO}_{2}$, $\mathrm{UO}_{2}-\mathrm{Gd}_{2} \mathrm{O}_{3}$, and $\mathrm{UO}_{2}-\mathrm{PuO}_{2}$ Rods From the Quad Cities-1 Reactor," EPRI NP-2307-LD, Electric Power Research Institute, prepared by General Electric Company, Interim Report (March 1982).

5. EPRI NP-214. "Gamma Scan Measurements at Quad Cities Nuclear Power Station Unit 1 Following Cycle 2," EPRI NP-214, Electric Power Research Institute, prepared by General Electric Company, Final Report (July 1976).

6. HELIOS-DOC. "HELIOS: Angularly Dependent collision Probabilities," Eduardo A. Villarino et al., Nucl. Sci. \& Eng., Volume 112, pp.16-31.

7. NEDC-25492. "Gamma Scan Measurements at Quad Cities 1 Following Cycle 4," NEDC25492, General Electric Company, San Jose, CA (November 1981).

8. NEDO-32638. "Optimization and Implementation Study of Plutonium Disposition Using Existing GE Boiling Water Reactors," GE Nuclear Energy, September 30, 1996.

9. GE-CONVER. Conversations with General Electric personnel, General Electric Corporation (September 1997).

10. QUAD-CONVER. Conversation with Commonwealth Edison personnel, Commonwealth Edison (October 1997).

11. SCALE-DOC. "SCALE 4.3: Modular Code System for Performing Standaradized Computer Analyses for Licensing Evaluation for Workstations and Personal Computers," Oak Ridge National Laboratory, CCC-545 (September 1995). 
,

, 


\section{APPENDIX A. HISTORICAL ASSESSMENT OF QUAD CITIES (BWR) MOX IRRADIATION}

\section{INTRODUCTION}

The early program associated with the use of MOX in BWRs started with a series of irradiations in the Vallecitos BWR. The testing proceeded with the irradiation of rods containing Dresden selfgenerated plutonium. Four MOX bundles containing a single MOX rod per bundle were inserted into Dresden 1 in 1967. Because of the limited scope, the small amounts of MOX that were employed, and the fact that later irradiation data from other reactors were more plentiful, no further consideration of the Dresden irradiations was undertaken. Based on these considerations, a judgment was made that this irradiation would not be specifically researched for information.

The start of an extensive series of domestic BWR irradiations in the Big Rock Point Reactor (BRP) commenced with the loading of 16 bundles (each containing 2 MOX rods) in May 1969. GE and Exxon Nuclear fabricated bundles for BRP. BRP was considered to be a test bed for MOX fuel during the mid 1970s. Plutonium concentrations ranged from 1.2 to $9.1 \mathrm{wt} \%$, with burnups performed in excess of $30 \mathrm{GWd} / \mathrm{t}$. Some BRP rods were ramp tested under power excursion conditions. The BRP irradiations provided valuable data needed to proceed with MOX utilization. A license allowing up to $50 \mathrm{~kg}$ of plutonium was issued. In terms of domestic irradiations, BRP has the most extensive experience with MOX fuel. According to ORNL/MD/LTR 40, Consumer's Power loaded 18 (Exxon Nuclear) 11 by 11 bundles, each containing 24 MOX rods in 1974. Eight additional MOX (Exxon Nuclear) bundles were loaded in 1976. However, according to reference NRC-GINNA, the sequential loading of MOX rods (produced by Exxon Nuclear) consisted of 2, 6, 12, 8, and 1411 by 11 bundles.

Extensive testing using the "island" design concept was also performed in the Quad Cities reactor. The "island" assembly design has MOX rods in the center of the fuel assembly surrounded by $\mathrm{UO}_{2}$ rods. Initially, the Vermont Yankee reactor was scheduled to be the host reactor for these irradiations. However, because of licensing issues, the fuel was redesigned and modified for insertion into the Quad Cities-1 reactor. A license to operate the MOX fuel was granted to Commonwealth Edison in June 1974, and five assemblies were inserted into Quad Cities at the beginning of cycle 2. The Quad Cities irradiation constitutes the most recent testing of MOX fuel performed in a U.S. BWR. The information that has been currently reviewed also indicates that the most comprehensive fuel testing on BWR fuel was performed on the Quad Cities fuel.

\section{DESCRIPTION OF IRRADIATIONS AND MEASUREMENTS}

\subsection{QUAD CITIES MOX IRRADIATION TEST PROGRAM}

The loading arrangement for cycle 2 contained 660 initial 7 by 7 bundles, 237 by 7 reload bundles, 368 by 8 reload bundles and 5 MOX bundles, which were 7 by 7 bundles. The 5 bundles began operation July 21,1974 . A total of $48 \mathrm{MOX}$ fuel rods were placed into the core initially. Four (GEB158, 159, 160, and 161, each containing $10 \mathrm{MOX}$ rods) of the 5 bundles were placed around the center control rod and operated there until discharge (although several reconstitutions were performed). A fifth bundle (GEB162) containing 8 rods was located at the core periphery. This edgeloaded assembly provided information for a low-power, hard neutron flux environment for the MOX fuel. In addition, information for such effects as leakage, thermal flux gradient, and flow conditions at the reflector were provided.

The 48 rods contained $80 \%-90 \%$ fissile $\mathrm{PuO}_{2}$ derived from recycled Dresden 1 fuel and USAEC material. (The isotopics are given on page 12-10 of EPRI NP-3568.) A total of four enrichments were 
used: 2.34 and $3.62 \mathrm{wt} \%$ Pu fissile for hollow pellets, and 2.14 and $3.52 \mathrm{wt} \%$ Pu fissile for solid pellets. Five gadolinium oxide rods were used in the central bundles to increase the shutdown margin.

During cycle 2, the control rod was fully withdrawn in the latter part of the cycle. Following the completion of cycle 2, nine fuel rods from GEB 161 and six rods from GEB162 were discharged for destructive examinations. Rods were shuffled between bundles, some shuffled within bundles, and 15 fresh $\mathrm{UO}_{2}$ rods were inserted to replace the discharged rods. Five rods from each of bundles GEB158 and GEB 159 were swapped, and all of the $\mathrm{UO}_{2}$ rods under surveillance from the central bundles were placed into one bundle. (EPRI-NP-3568).

The five bundles were irradiated in cycle 3 . There were some control rod effects on the MOX assemblies because the control blade was left $1 / 3$ inserted during the last 60 of the cycle, and these were reflected in the measurements. The current documentation (NP-2302-LD) indicates that two MOX bundles (GEB 159 and GEB162) were diasassembled to perform a gamma scan on some single rods at the end of cycle 3 . Some external mechanical modifications were made at many of the refueling outages which had no effect on the bundle design.

Operating information for cycles 1-3 is summarized in EPRI NP-240 and EPRI NP-552 (which has been obtained). These operating data reports describe the burnup steps that were taken and cite the axial power distributions measured during the cycle using the traversing incore probes (TIPs). Operating information for cycles 4 and 5 has not been located but may be found in NEDC-25490 and NEDC-25491.

At the end of cycle 5 , the four central bundles were discharged and a new bundle designated GEB159 (delta) was reconstituted from rods out of GEB158, GEB159, and GEB161. With respect to the FMDP and individual rod destructive test data, rod VP0017, which is a solid MOX rod, provides some valuable performance data.

The reconstituted bundle from EOC 5 was inserted into the previous GEB159 position and irradiated during cycle 6 . At the end of cycle 6, bundles GEB 159 (delta) and GEB162 (containing MOX fuel rods) were discharged from the reactor. Annular and solid MOX rods were irradiated in excess of 55,000 MWd/t, thereby providing high-burnup-fuel performance information. The EOC 6 results have not been located in the open literature.

\subsection{QUAD CITIES MEASUREMENTS AND TESTS (applicable to possible reactor physics benchmarks)}

An overall description of the measurements taken on all of the rods is contained in Table 2.1 and 2.2 of EPRI-NP-3568. The program was quite extensive, encompassing measurements that are valuable from both a reactor physics viewpoint and a materials performance viewpoint. The measurements taken at Quad Cities considered to be applicable (with respect to providing a possible physics-related benchmark) are described below.

Gamma Scans. Gamma scans (bundle and some individual rods) were taken following cycles 2-4. Cycle 5 and 6 measurements were also performed, but under a separate GE program. The gamma scans "look" for the ${ }^{140} \mathrm{La}$, which is a daughter of ${ }^{140} \mathrm{Ba}$. The ${ }^{140} \mathrm{Ba}$ distribution in the fuel is a characteristic of the last $60 \mathrm{~d}$ of reactor operation. Thus, the primary objective of the scans is to provide a benchmark for the power distribution. Bundles are typically scanned at 12 different elevations and sometimes 24 elevations for greater detail. Individual rod measurements generally covered 8 locations and provide pin-to-pin power distribution benchmarks. Three topical reports cover cycles 2, 3, and 4 gamma-scan measurements (the first two are EPRI reports; the fourth cycle is an NEDC document, see pp. 7-21 of EPRI-NP3568).

Following cycles 2 and 3, all five MOX bundles were scanned. From the existing documentation, it is apparent that bundle scans were performed for EOC4, but the information concerning individual rod scans is not clear. In addition, an eighth of the core was scanned to assess the gross power shape and reload bundle power sharing. Rod-to-rod planar power distributions for 
EOC 2 and bundle GEB-162 are shown in EPRI-NP3568. Rod-to-rod planar power distributions for EOC 3 and bundle GEB-159 are also shown in EPRI-NP3568. It is thought that a considerable amount of data exist in the EPRI reports and NEDC documents referred to above. Even though EPRI-NP3568 cites the value of these measurements in terms of an "accurate data base against which power distribution calculations and on-line power measurement systems have been and continue to be compared," the comparison between measurements and calculation has not been found.

More information concerning the EOC (2,3, and 4) gamma scans are provided in Sect. 12.3 .5 of EPRI-NP 3568. The axial linear heat generation rate is given for one solid MOX rod and for a number of other rods (annular $\mathrm{MOX}$ and $\mathrm{UO}_{2}$ ) at EOC 2,3, and 4. The comparison of prediction and measurements is given in this section. These heat rates are important as an input into the predictions of fission gas release. Additional information is also given in NP-2302-LD for the end-of-cycle-3 measurements.

Gadolinia depletion. Gadolinia was incorporated into a number of the $\mathrm{UO}_{2}$ rods. Measurements on gadolinia depletion were performed at the end of cycle 2 . Currently, gadolinia depletion is not an issue for the MOX fuel. However, it is mentioned here only from the standpoint that the widespread use of MOX will change the flux spectra and thus the gadolinia burnout in standard $\mathrm{UO}_{2}$ bundles might possibly be called into question.

Cold Critical Measurements (Performed at the Start of Cycle 4). The shutdown margin with the "one rod stuck condition" (cold core) is an important criterion to be met. At the start of cycle 4, two full-length flux wires were inserted and criticality was performed by two control blade withdrawals. The wires were withdrawn, and an activation analysis was performed. From these two wires a fast flux (from a nickel wire) and a thermal flux axial shape (from a copper wire) were measured. This measurement was compared with calculations and was found to be in good agreement with the calculated value (see Figs. 10.3 and 10.4, EPRI-NP3568). It was stated that these flux distributions agreed well with the calculations. The calculated eigenvalue was quoted as 1.007 , which was noted to be consistent with other calculations performed (EPRI-NP-3568). This experiment was conducted because there was interest with respect to how well the diffusion theory code could predict steep flux gradients.

Isotopic determinations. At the end of cycle 2, a total of 15 fuel rods were removed (from two bundles) and isotopic determination measurements were performed on these rods (see pp. 11-3 and 4; EPRI-NP 3568). Nine of the rods came from central bundle GEB161 (average burnup of 9160 $\mathrm{MWd} / \mathrm{t}$ ). A total of eight MOX rods (four solid, four annular) were sampled with two annular and two solid rods from each bundle. The pellet samples were taken at four different axial planes-53.3, $144.8,236.2$, and $327.7 \mathrm{~cm}$ above the bottom of the active fuel. Battelle was responsible for sample preparation, and the GE Vallecitos hot cell facility was used to perform the measurements. Alpha spectroscopy was used to measure ${ }^{237} \mathrm{~Np},{ }^{242} \mathrm{Cm}$, and ${ }^{241} \mathrm{Am}$. Total americium and curium concentrations were also analyzed.

Atom density ratios for ${ }^{235} \mathrm{U},{ }^{239} \mathrm{Pu}$ and ${ }^{241} \mathrm{Pu}$ were measured as a function of burnup. In addition ${ }^{237} \mathrm{~Np},{ }^{241} \mathrm{Am}$, and ${ }^{242} \mathrm{Cm}$ were also measured. The results are documented in Sect. 11 of EPRI-NP3568. Since only one cycle of irradiation was conducted, only low-burnup-value (up to about 13,500 $\mathrm{MWd} / \mathrm{t}$ ) data were reported in EPRI-NP-3568.

Radial samples were also taken. The distribution of ${ }^{155} \mathrm{Gd}$ and ${ }^{157} \mathrm{Gd}$, along with ${ }^{235} \mathrm{U}$ depletion, ${ }^{239} \mathrm{Pu}$ and ${ }^{241} \mathrm{Pu}$ buildup is shown (for a $\mathrm{UO}_{2}$ rod). Radial power shapes are thought to be useful because these shapes influence fission-gas release rates. The detailed mass spectrometric measurements on the gadolinia isotopes are quoted to be useful for checking cross-section libraries.

Specific nuclide information for the EOC 5 measurements have not been found. Except for the information provided below, the extent of examination is not known.

Burnup Gamma Scans (Linear-Heat-Generation Rate). One of the solid MOX rods (VP0017, which was loaded with $90 \%$ fissile plutonium) was scanned for gross gamma and ${ }^{137} \mathrm{Cs}$ gammas at the end of cycle 5. This rod had an average burnup of $35,000 \mathrm{MWd} / \mathrm{t}$. In addition, fission 
gas release measurements were made providing a benchmark (which found that the annular pellets released more fission gas than the solid pellet) for BWR fuel. Power and temperature history is a significant uncertainty associated with the interpretation of fission gas measurements. The linear heat generation rate based on measured gamma scans for VP-0017 is shown in Figs. 12.3-12.5 and

Fig. 12.7 (EPRI-NP-3568). EPRI-NP-3568 states that fine-mesh power histories would be desirable to have, which would allow for a comparison with the measured data. In addition to gross gamma scans, data are also presented for ${ }^{137} \mathrm{Cs}$, which is a measure of burnup. 


\section{APPENDIX A. REFERENCES}

ORNL/MD/LTR 40. "Survey of Worldwide Light Water Reactor Experience with Mixed Uranium-Plutonium Oxide Fuel, Draft Letter Report," draft of October 11, 1995.

EPRI NP-3568. "Quad Cities Nuclear and Fuel Performance Measurement," EPRI NP-3568,

Electric Power Research Institute, prepared by General Electric Company (July 1984).

EPRI NP-240. "Core Design and Operating Data for Quad Cities 1 Cycle 2," EPRI NP-240,

Electric Power Research Institute, prepared by General Electric Company (November 1976).

EPRI NP-552. "Core Design and Operating Data for Quad Cities 1 Cycle 3," EPRI NP-552,

Electric Power Research Institute, prepared by General Electric Company (March 1983).

EPRI NP-2302-LD. "Gamma Scan Measurements at Quad Cities Nuclear Power Station Unit-1

Following Cycle 3," EPRI NP-2302-LD, Interim Report (March 1982).

EPRI NP-2307-LD. "Burnup and Transuranium Element Composition in Irradiated $\mathrm{UO}_{2}, \mathrm{UO}_{2}$ $\mathrm{Gd}_{2} \mathrm{O}_{3}$, and $\mathrm{UO}_{2}-\mathrm{PuO}_{2}$ Rods From the Quad Cities-1 Reactor," EPRI NP-2307-LD, Electric Power

Research Institute, prepared by General Electric Company, Interim Report (March 1982).

EPRI NP-214. "Gamma Scan Measurements at Quad Cities Nuclear Power Station Unit 1

Following Cycle 2," EPRI NP-214, Electric Power Research Institute, prepared by General Electric Company, Final Report (July 1976).

NRC-GINNA. "Summary of Meeting Held on November 1, 1979," Letter from James J. Shea (NRC) to Rochester Gas \& Electric Company (RG\&E).

NEDO-32638. "Optimization and Implementation Study of Plutonium Disposition Using

Existing GE Boiling Water Reactors," GE Nuclear Energy, September 30, 1996. 
. 


\section{APPENDIX B. GEB-161 SURROUNDING ASSEMBLY DATA}

Figures B.1-B.7 show the pin cell locations associated with the fuel type of the surrounding assemblies for cycle 2. Definitions of fuel types (numerical indices) are given in Tables B.1, B.2, and B.3. The axial gadolinium zoning for bundles (other than GEB 158-161) is shown in B.8. This information was taken from EPRI NP-240. The top of each page represents "reactor" north; thus, the computational model can be composed with the pin cells exactly as shown, and no transposition of the locations is necessary.

Figure B.9 shows the suggested cycle 1 nine-bundle arrangement to use if adjoining bundles are to be burned prior to the cycle 2 depletion. The term suggested is used because it is acknowledged that CX-0261was not actually in the location shown in Fig. B.9 (because it was shuffled). Bundles CX-189, CX-199, CX-155, and CX-272 are Type 1a initial fuel and thus have same assembly design as CX-0310 and CX-0261 shown in Fig. B.1. However, the fuel rod locations in Fig. B.1 must be transposed as appropriate. 
Wide/Wide

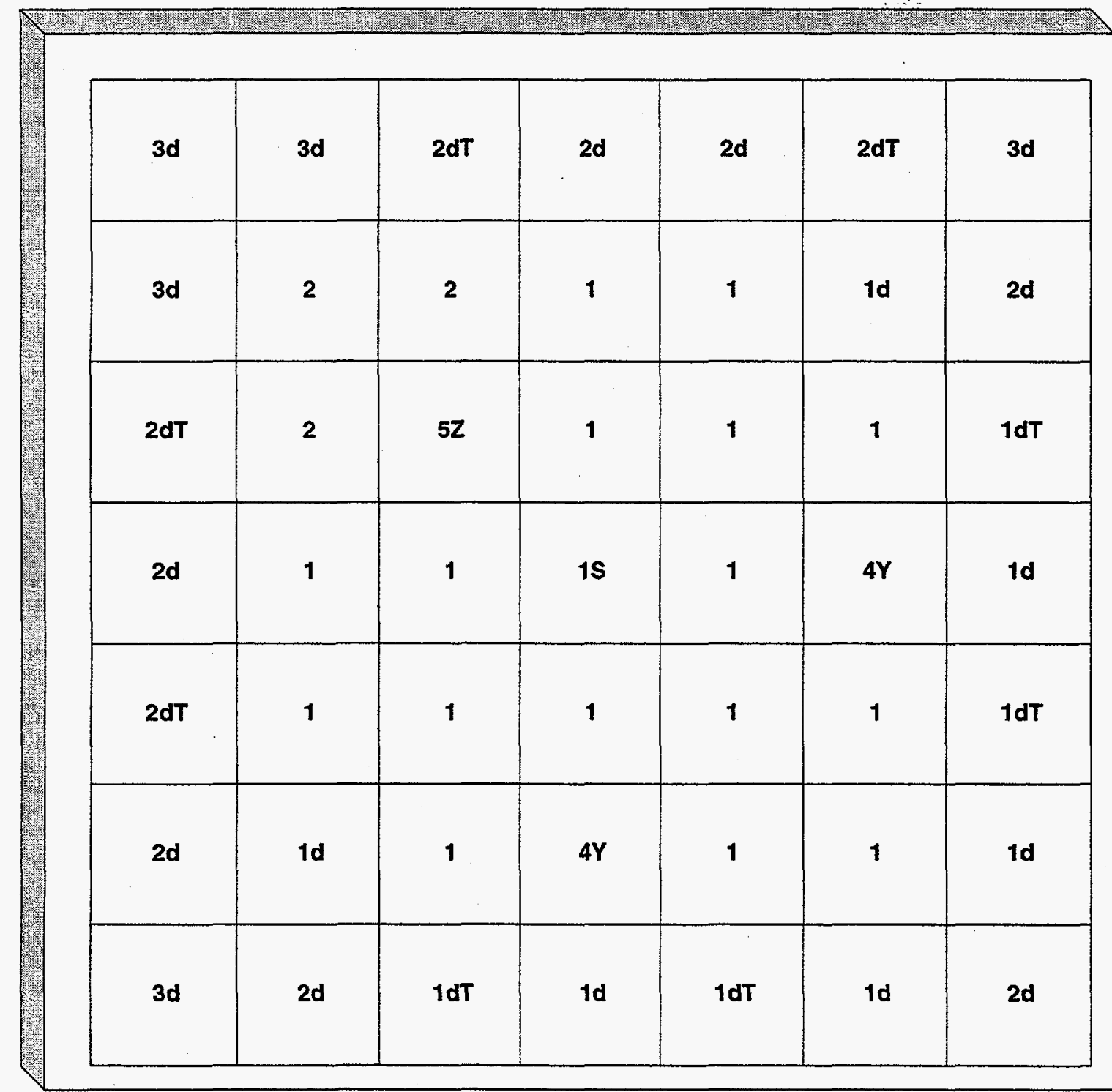

NOTE:

Narrow/Narrow

$S=$ Spacer capture rod

$T=$ Tie rod

$d=$ Dished rod in a dished bundle

Fig. B.1. CX-0310 and CX-0261 assemblies. 
Narrow/Narrow

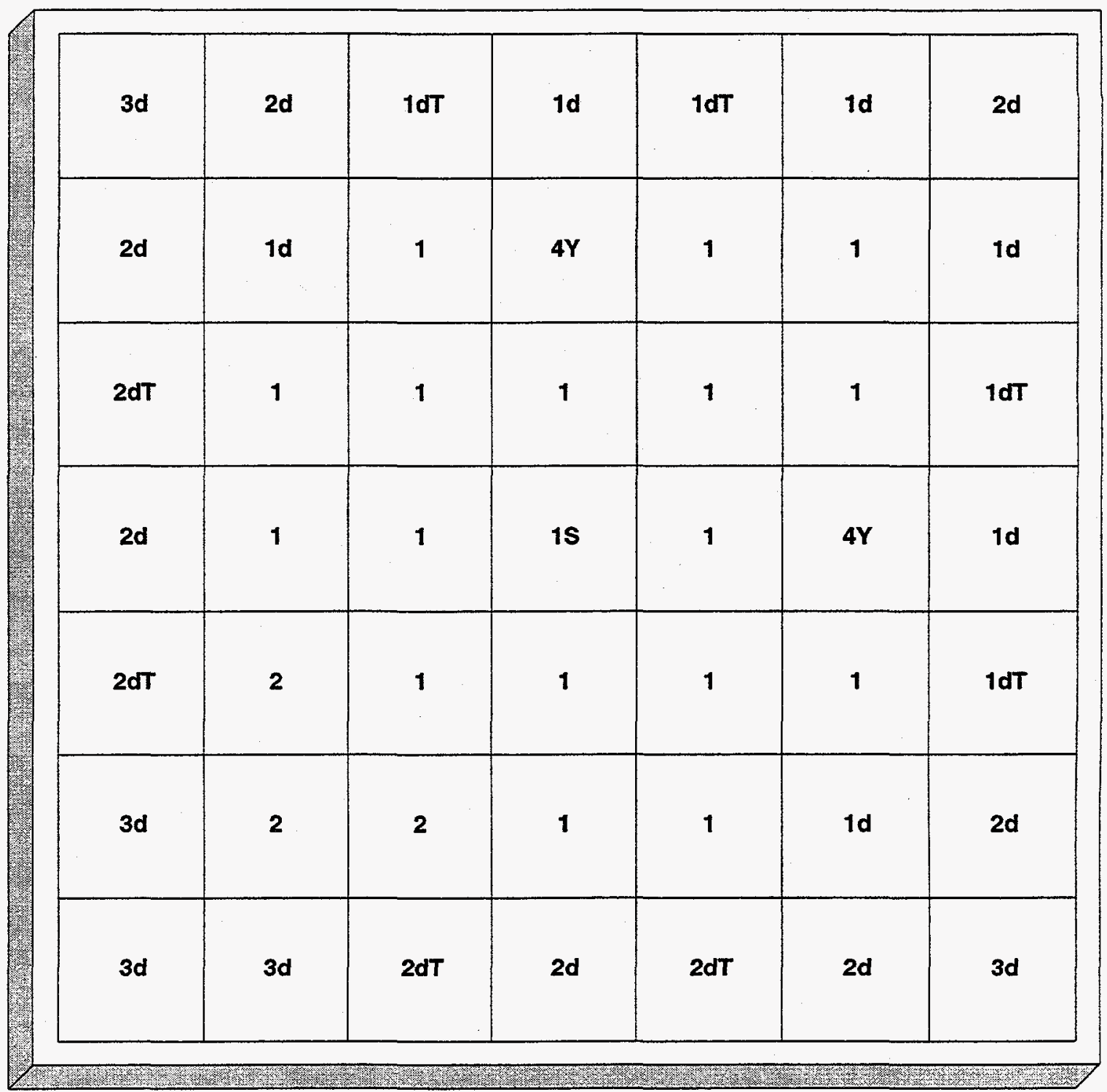

Wide/Wide

NOTE:

$\mathbf{S}=$ Spacer Capture Rod

$\mathbf{T}=$ Tie Rod

$\mathrm{d}=$ Dished Rod in a Dished Bundle

Fig. B.2 CX-0482 assembly. 
Wide/Wide

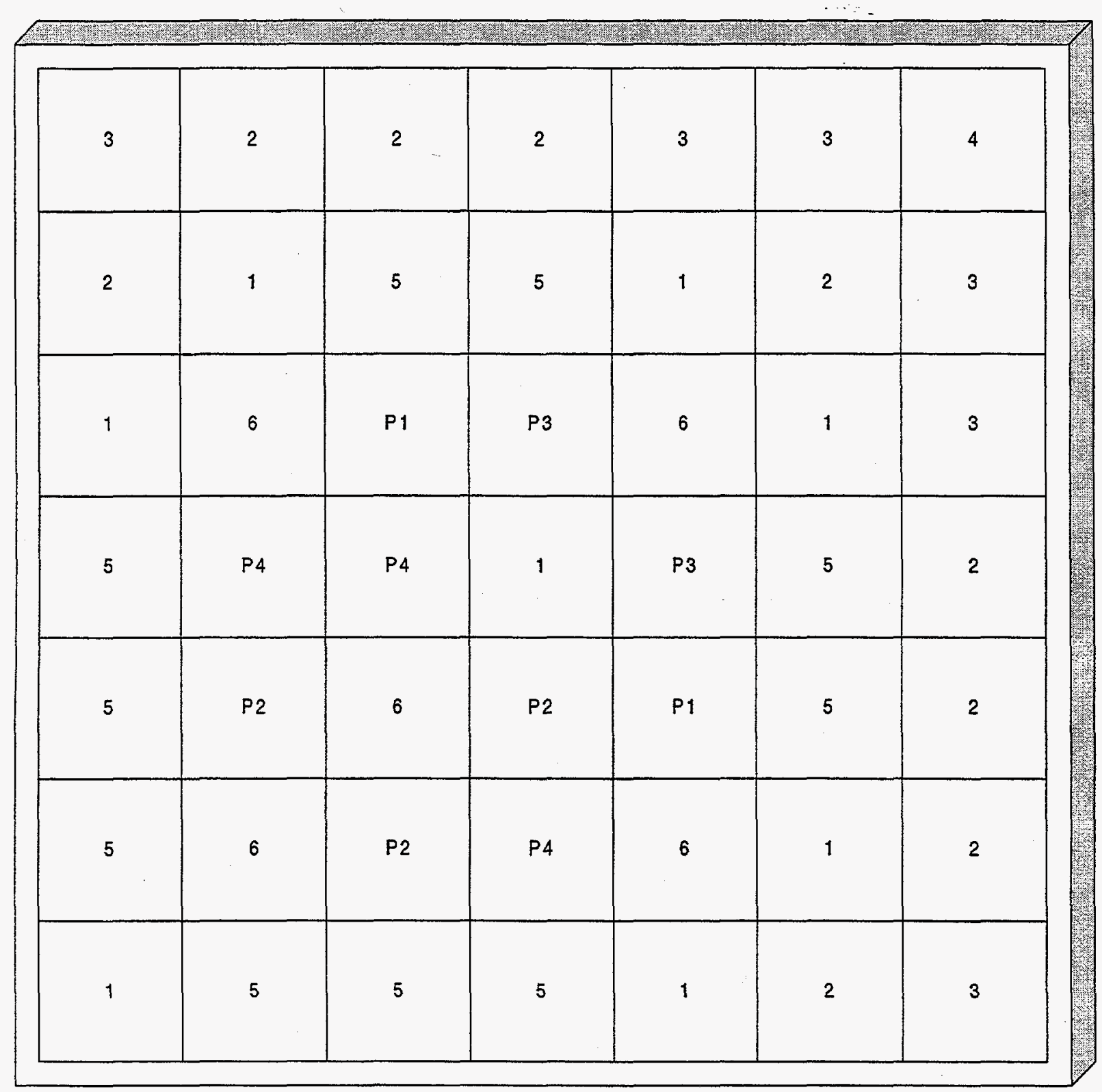

Narrow/Narrow

Fig. B.3. GEB-158 assembly. 
Wide/Wide

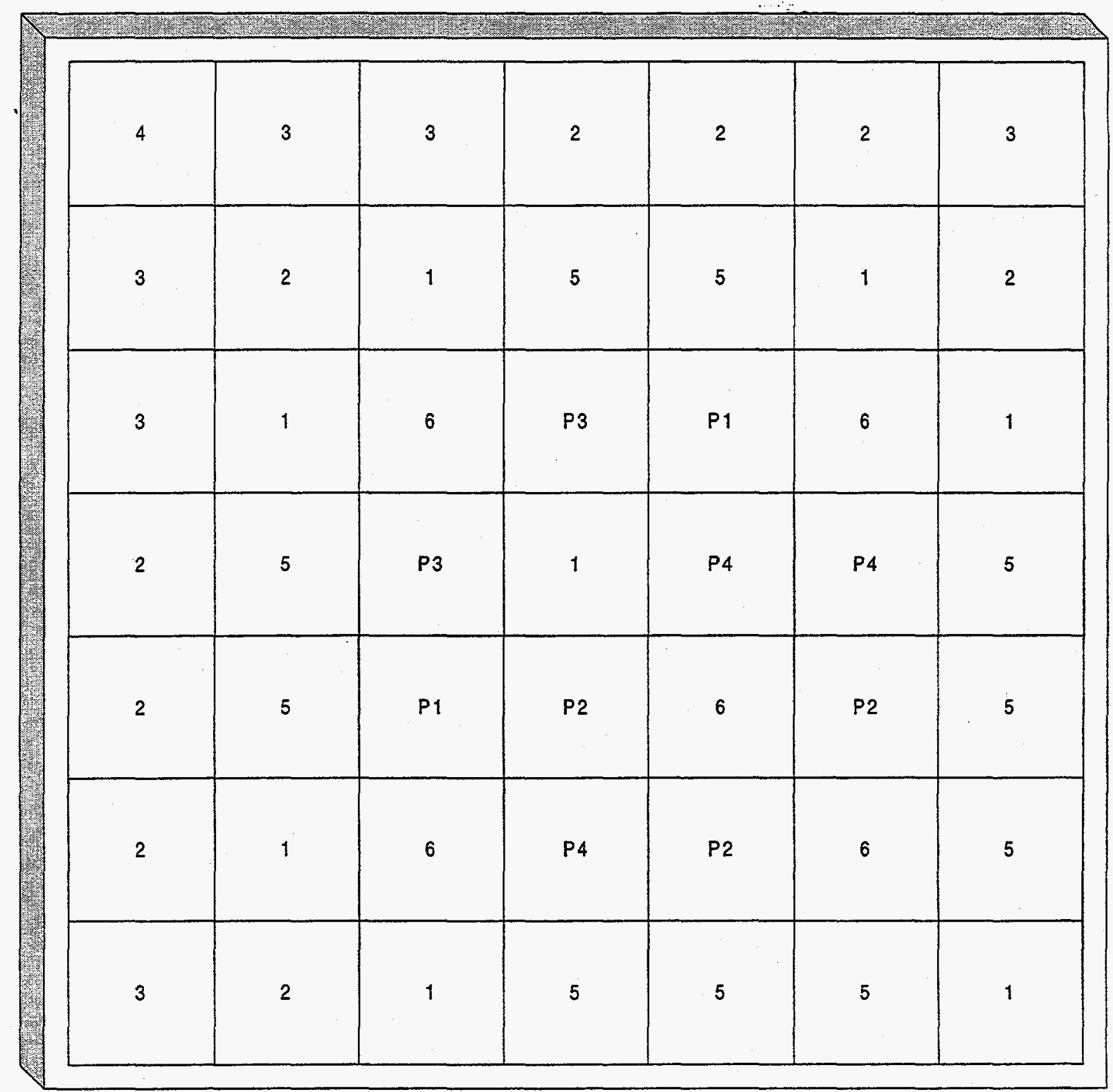

Narrow/Narrow

Fig. B.4. GEB-160 assembly. 


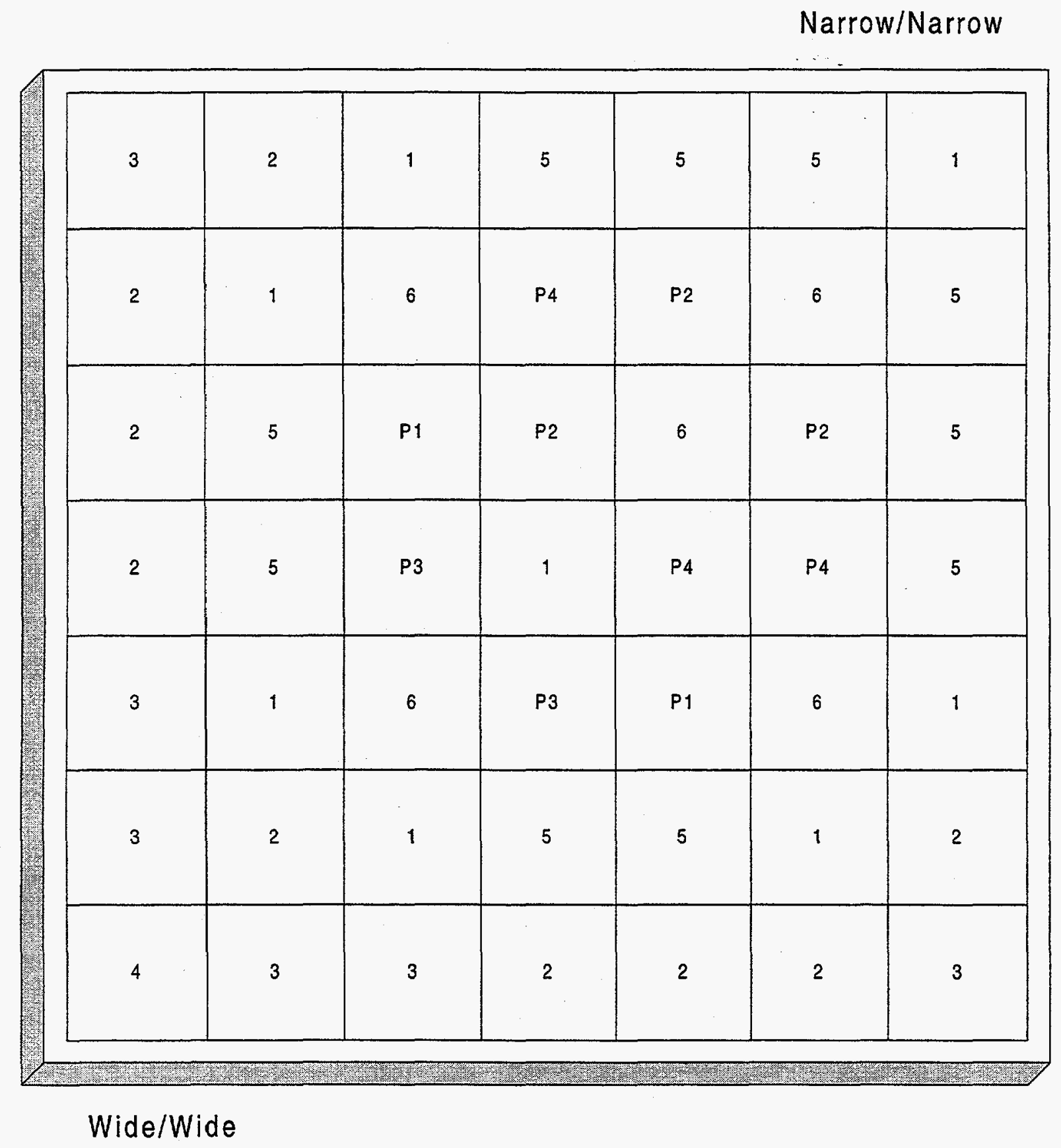

Fig. B.5. GEB-159 assembly. 


\section{Wide/Wide}

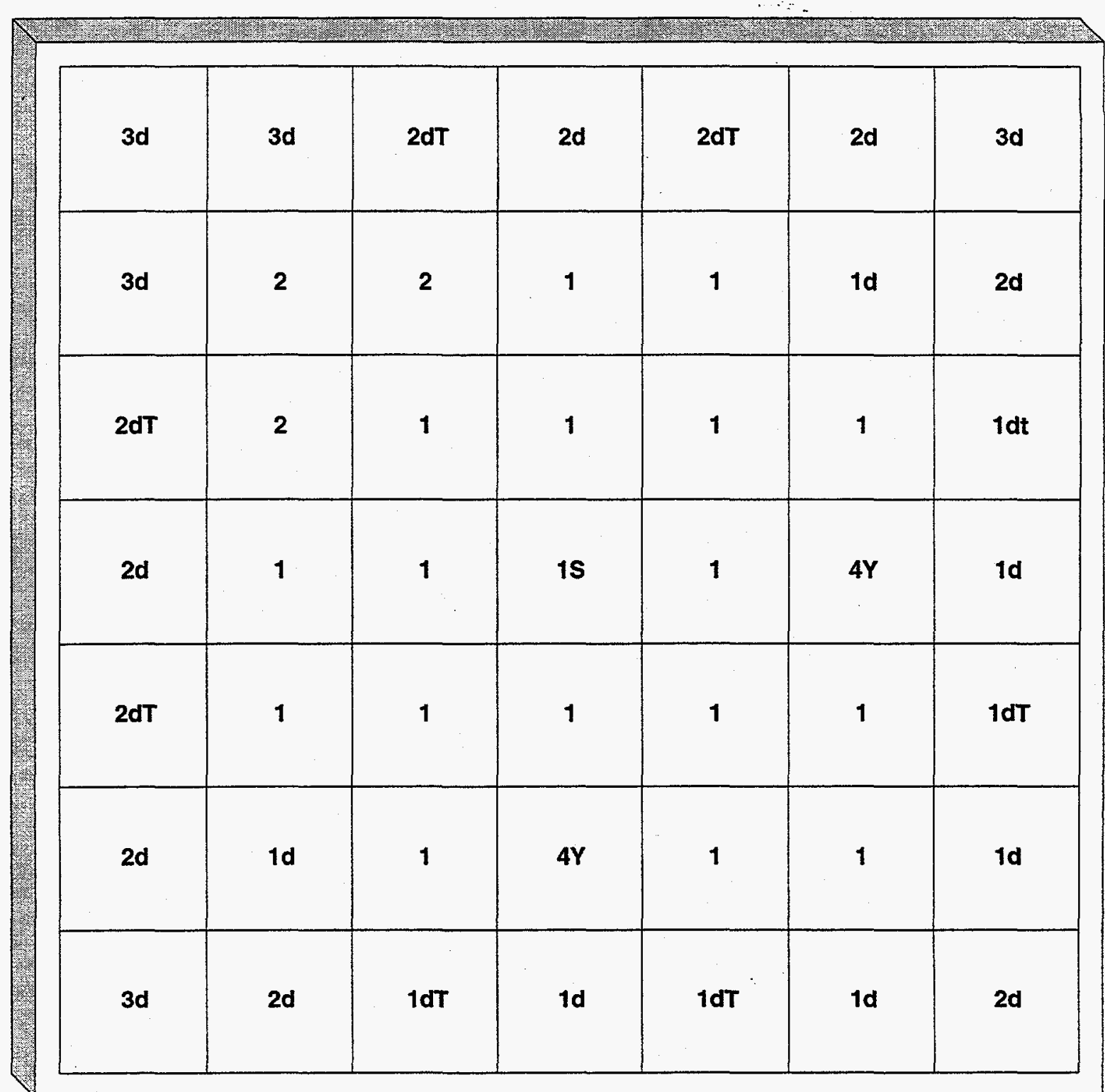

NOTE:

Narrow/Narrow

S = Spacer capture rod

$T=$ Tie Rod

$\mathrm{d}=$ Dished rod in a dished bundle

Fig. B.6. CX-0575 assembly. 


\section{Wide/Wide}

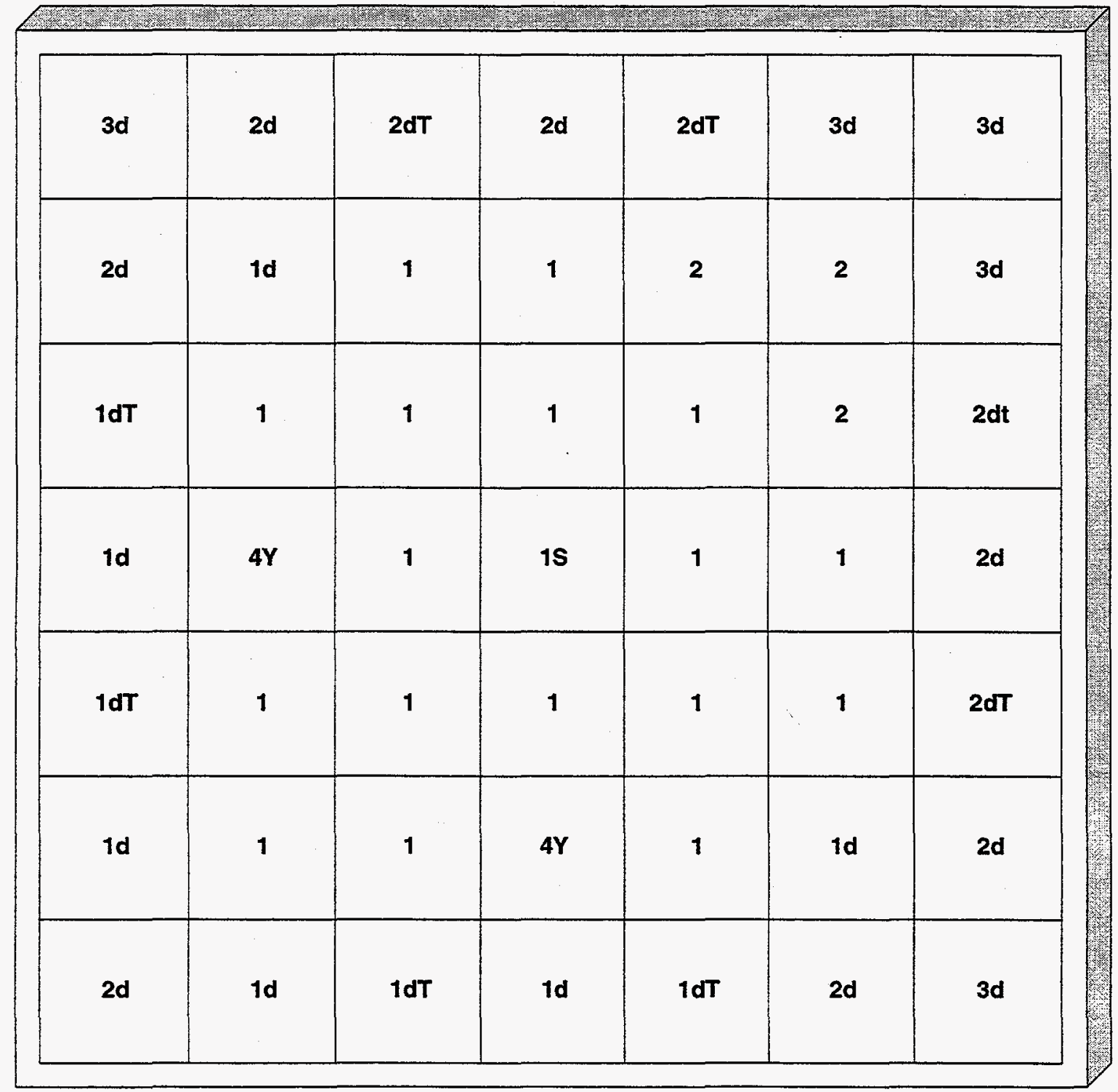

\section{Narrow/Narrow}

NOTE:

$\mathrm{S}=$ Spacer capture rod

$T=$ Tie rod

$\mathbf{d}=$ Dished rod in a dished bundle

Fig. B.7. CX-0516 assembly. 
TYPE Z

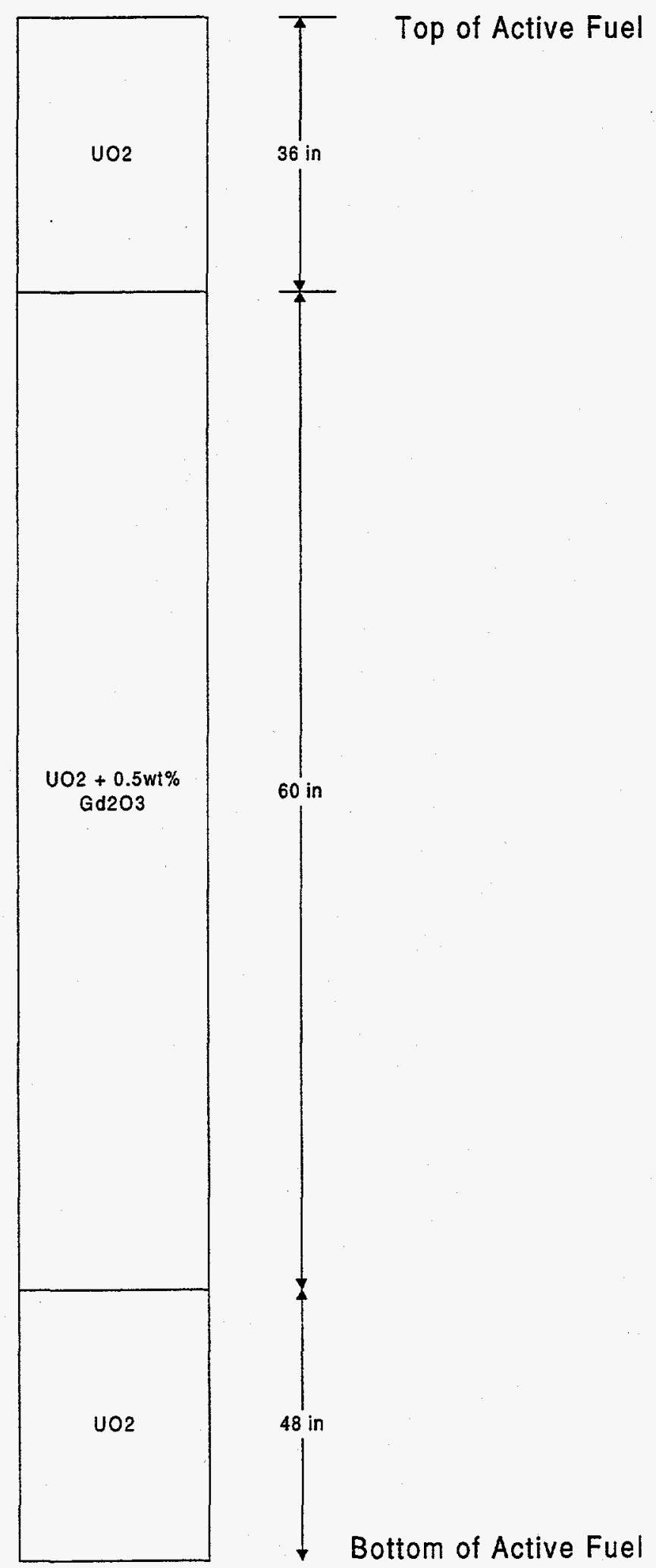

TYPE Y

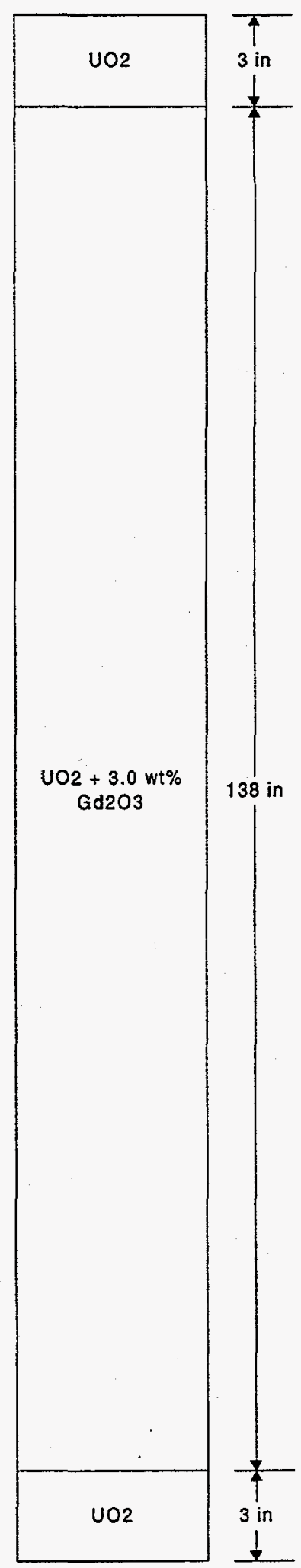

Fig. B.8. Gd stack types (bundles other than MOX bundles). 


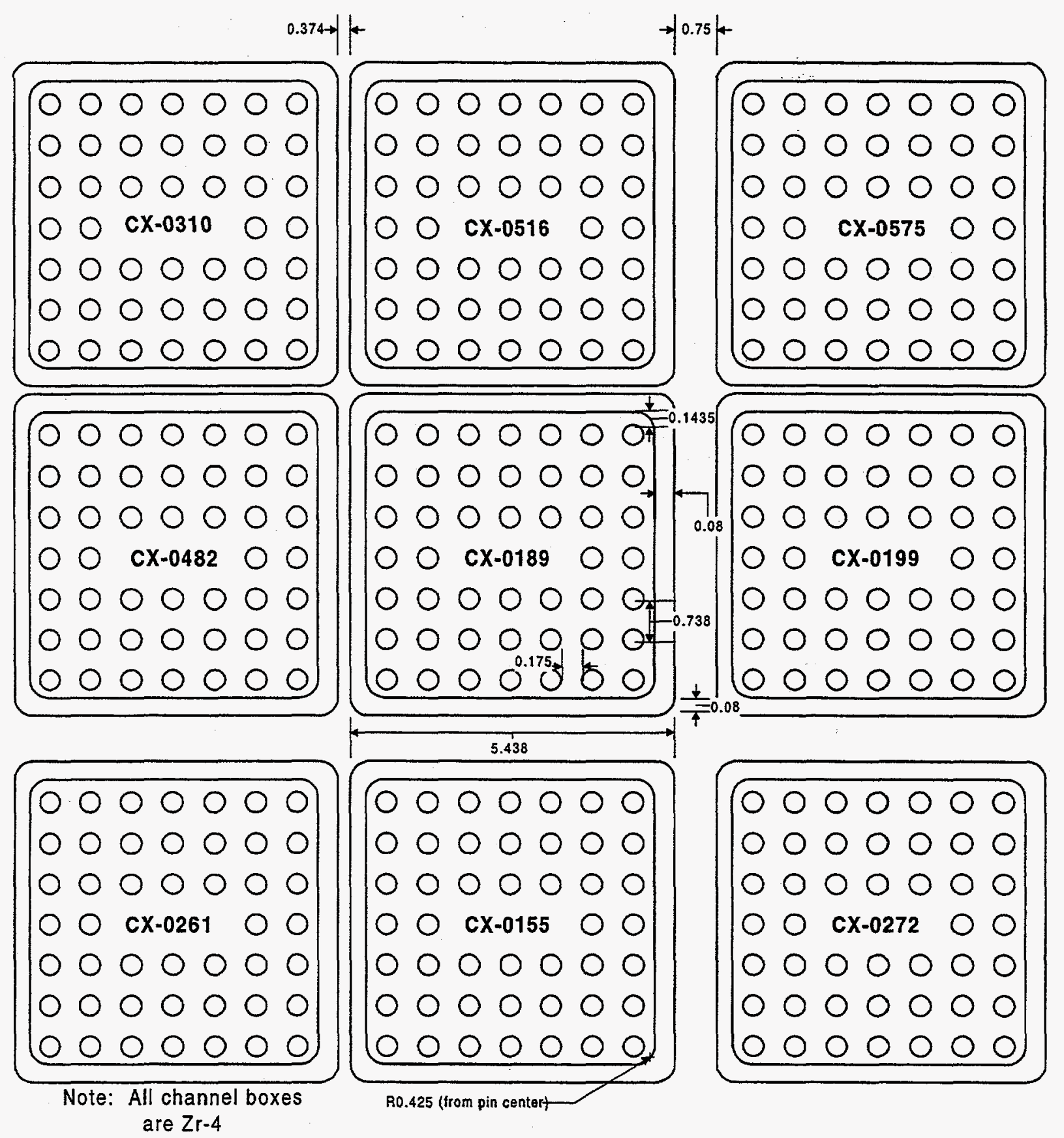

Fig. B.9. Suggested cycle 1 bundle arrangement. 
Table B.1. Type 1a initial fuel

(Contains $2.12 \mathrm{wt} \%{ }^{235} \mathrm{U}$ bundle average)

(ref: EPRI NP-240, combined pp. A-3 with pp. C-1)

\begin{tabular}{ccccccc}
\hline & & & & \multicolumn{2}{c}{ Zirc-2 clad } \\
Rod type & No. of rods & $\begin{array}{c}\mathbf{2 3 5}_{\mathbf{U}} \\
(\mathbf{w t} \mathbf{\%})\end{array}$ & $\begin{array}{c}\mathbf{G d}_{\mathbf{2}} \mathbf{O}_{\mathbf{3}} \\
(\mathbf{w t} \%)\end{array}$ & $\begin{array}{c}\text { Stack density } \\
\left(\mathbf{g} / \mathbf{c m}^{\mathbf{3}}\right)\end{array}$ & $\begin{array}{c}\text { OD } \\
\text { (in.) }\end{array}$ & $\begin{array}{c}\text { Wall thickness } \\
\text { (in.) }\end{array}$ \\
\hline 1 & 16 & 2.47 & 0 & 10.34 & 0.563 & 0.032 \\
$1 \mathrm{~d}$ & 10 & 2.47 & 0 & 9.94 & 0.563 & 0.032 \\
$1 \mathrm{~s}$ & 1 & 2.47 & 0 & 10.34 & 0.563 & 0.032 \\
2 & 3 & 1.70 & 0 & 10.34 & 0.563 & 0.032 \\
$2 \mathrm{~d}$ & 11 & 1.70 & 0 & 9.94 & 0.563 & 0.032 \\
$3 \mathrm{~d}$ & 5 & 1.20 & 0 & 9.94 & 0.563 & 0.032 \\
$4 \mathrm{Y}$ & 2 & 2.47 & 3.0 & 10.26 & 0.563 & 0.032 \\
$5 Z$ & 1 & 2.47 & 0.5 & 10.34 & 0.563 & 0.032 \\
\hline
\end{tabular}

Table B.2. Type 2a initial fuel

(Contains 2.12 wt \% ${ }^{235} \mathrm{U}$ bundle average)

(ref: EPRI NP-240, combined pp. A-4 with pp. C-2)

\begin{tabular}{ccccccc}
\hline Rod type & No. of rods & $\begin{array}{c}{ }^{235} \mathbf{U} \\
(\mathbf{w t} \%)\end{array}$ & $\begin{array}{c}\mathbf{G d}_{\mathbf{2}} \mathbf{O}_{3} \\
(\mathbf{w t ~ \% )}\end{array}$ & $\begin{array}{c}\text { Zirc-2 clad } \\
\text { stack density } \\
\left(\mathbf{g} / \mathbf{c m}^{3}\right)\end{array}$ & $\begin{array}{c}\text { OD } \\
\text { (in.) }\end{array}$ & $\begin{array}{c}\text { Wall thickness } \\
\text { (in.) }\end{array}$ \\
\hline 1 & 17 & 2.47 & 0 & 10.34 & 0.563 & 0.032 \\
1d & 10 & 2.47 & 0 & 9.94 & 0.563 & 0.032 \\
1s & 1 & 2.47 & 0 & 10.34 & 0.563 & 0.032 \\
2 & 3 & 1.70 & 0 & 10.34 & 0.563 & 0.032 \\
2d & 11 & 1.70 & 0 & 9.94 & 0.563 & 0.032 \\
3d & 5 & 1.20 & 0 & 9.94 & 0.563 & 0.032 \\
4Y & 2 & 2.47 & 3.0 & 10.26 & 0.563 & 0.032 \\
\hline
\end{tabular}

Table B.3. Composition of MOX bundle GEB-161

(assembly type 5, ref: EPRI NP-240, p. A-6)

\begin{tabular}{|c|c|c|c|c|c|c|c|c|}
\hline Rod type & $\begin{array}{c}\text { No. of } \\
\text { rods }\end{array}$ & $\begin{array}{c}{ }^{235} U \\
\text { (wt } \% \text { of } U)\end{array}$ & $\begin{array}{c}\text { Fissile } \\
\text { Pu } \\
\text { (wt \%) }\end{array}$ & $\begin{array}{l}\mathrm{Gd}_{2} \mathrm{O}_{3} \\
(\mathrm{wt} \%) \\
\end{array}$ & $\begin{array}{c}\text { Stack } \\
\text { density } \\
\left(\mathrm{g} / \mathrm{cm}^{3}\right)\end{array}$ & $\begin{array}{c}\text { Pellet } \\
\text { OD }^{\mathbf{a}} \\
\text { (in.) } \\
\end{array}$ & OD (in.) & $\begin{array}{l}\text { clad } \\
\text { Wall } \\
\text { thickness } \\
\text { (in.) }\end{array}$ \\
\hline 1 & 8 & 2.56 & 0 & 0 & 10.32 & 0.477 & 0.563 & 0.037 \\
\hline 2 & 9 & 1.94 & 0 & 0 & 10.32 & 0.477 & 0.563 & 0.037 \\
\hline 3 & 6 & 1.69 & 0 & 0 & 10.32 & 0.477 & 0.563 & 0.037 \\
\hline 4 & 1 & 1.33 & 0 & 0 & 10.32 & 0.477 & 0.563 & 0.037 \\
\hline 5 & 10 & 3.30 & 0 & 0 & 10.32 & 0.477 & 0.563 & 0.037 \\
\hline 6 & 4 & 2.56 & 0 & 3.0 & 10.19 & 0.477 & 0.563 & 0.037 \\
\hline 7 & 1 & 2.56 & 0 & 2.5 & $10.19^{d}$ & 0.477 & 0.563 & 0.037 \\
\hline P1 (solid) & 2 & 0.72 & $2.14^{b}$ & 0 & $9.89^{e}$ & 0.487 & 0.563 & 0.032 \\
\hline P2 (solid) & 3 & 0.72 & $3.52^{c}$ & 0 & $9.89^{e}$ & 0.487 & 0.563 & 0.032 \\
\hline P3 (annul-0.15 ID) & 2 & 0.72 & $2.34^{b}$ & 0 & $8.94^{e}$ & 0.487 & 0.563 & 0.032 \\
\hline P4 (annul-0.15 ID) & 3 & 0.72 & $3.62^{c}$ & 0 & $8.94^{e}$ & 0.487 & 0.563 & 0.032 \\
\hline
\end{tabular}

${ }^{a} \mathrm{OD}=$ outside diameter.

${ }^{b} 80 \%$ Fissile blend; see following section. Fissile $\mathrm{Pu}$ is weight of ${ }^{239} \mathrm{Pu}$ and ${ }^{241} \mathrm{Pu}$ divided by total heavy metal based on Fig. 3.2, EPRI NP-2307-LD.

${ }^{c} 90 \%$ Fissile blend; see following section. Fissile $\mathrm{Pu}$ is weight of ${ }^{239} \mathrm{Pu}$ and ${ }^{241} \mathrm{Pu}$ divided by total heavy metal based on Fig. 3.2, EPRI NP-2307-LD.

${ }^{d}$ Stack density is from Fig. 3.2, EPRI NP-2307-LD.

${ }^{e}$ Value taken from EPRI NP-2307-LD, p. 3-3; conflicts with p. A-6 EPRI NP-240, which is quoted as 9.99 and 9.04 for $\mathrm{P} 1 / \mathrm{P} 2$ and $\mathrm{P} 3 / \mathrm{P} 4$, respectively. 



\section{APPENDIX C. ORNL HELIOS INPUT DECK LISTING}

+THEI

QUADS4=CASE ['library.bin' / 'quads4.hrf' /

'Central MOX BWR 161 at 11722MWd/t, saturated water at 286C,18 months cycle ')

! Quad City Central MoX Assembly \# 161 (top-left) White Boundary Cond.

Oct $16,97 \quad$ !

See changes in Pu pins: we input the correct number now (w\%/heavies) !

Nov 5,97 !

See two types of pins $\mathrm{UO}_{2}$ and MOX !

Nov 7,97 !

5 regions in Gd pins !

Dec 10, 97 !

! See right density of hollow MOX pin: 8.94 !

! -

!34567890123456789012345678901234567890123456789012345678901234567890123456 789 !

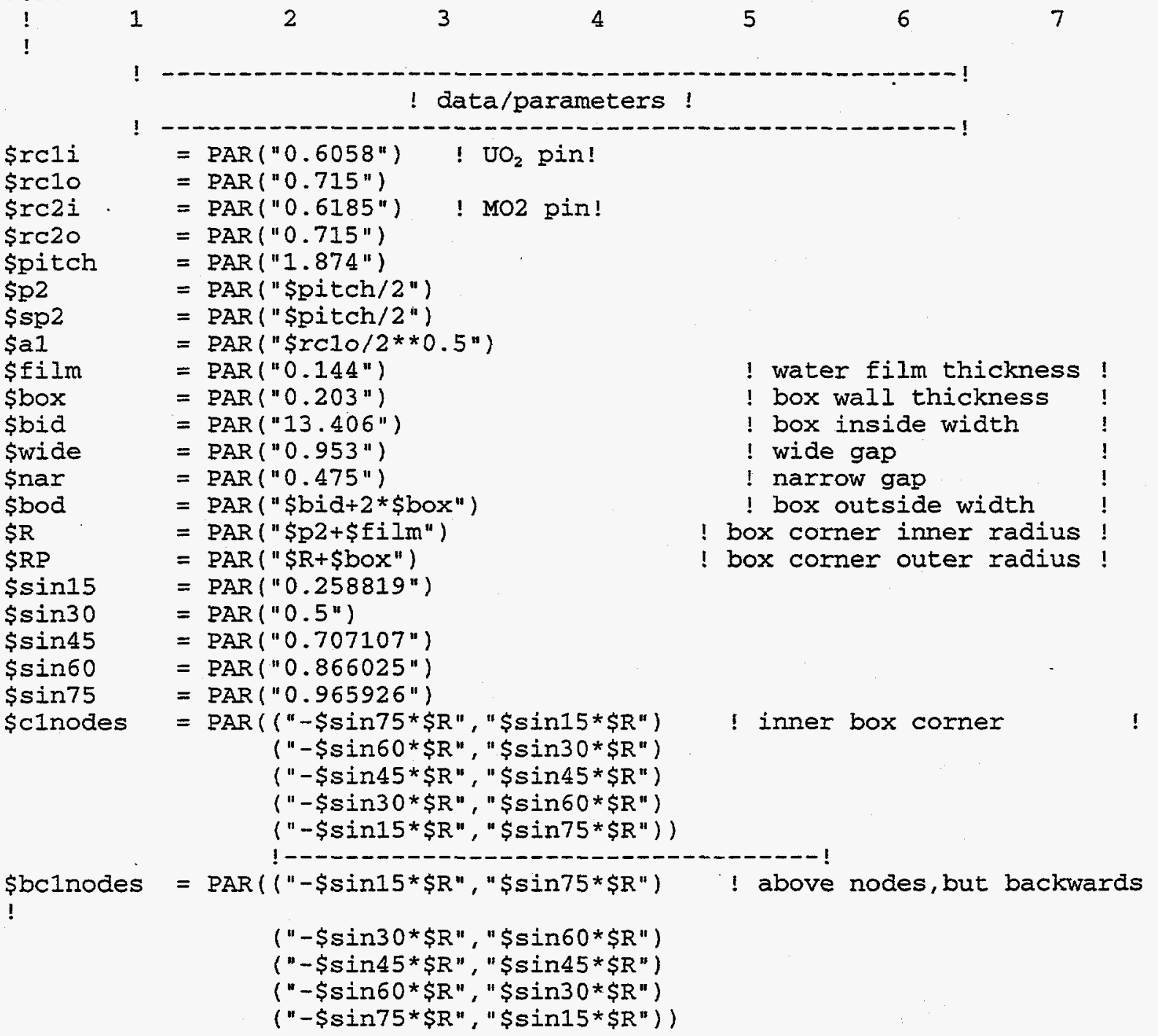




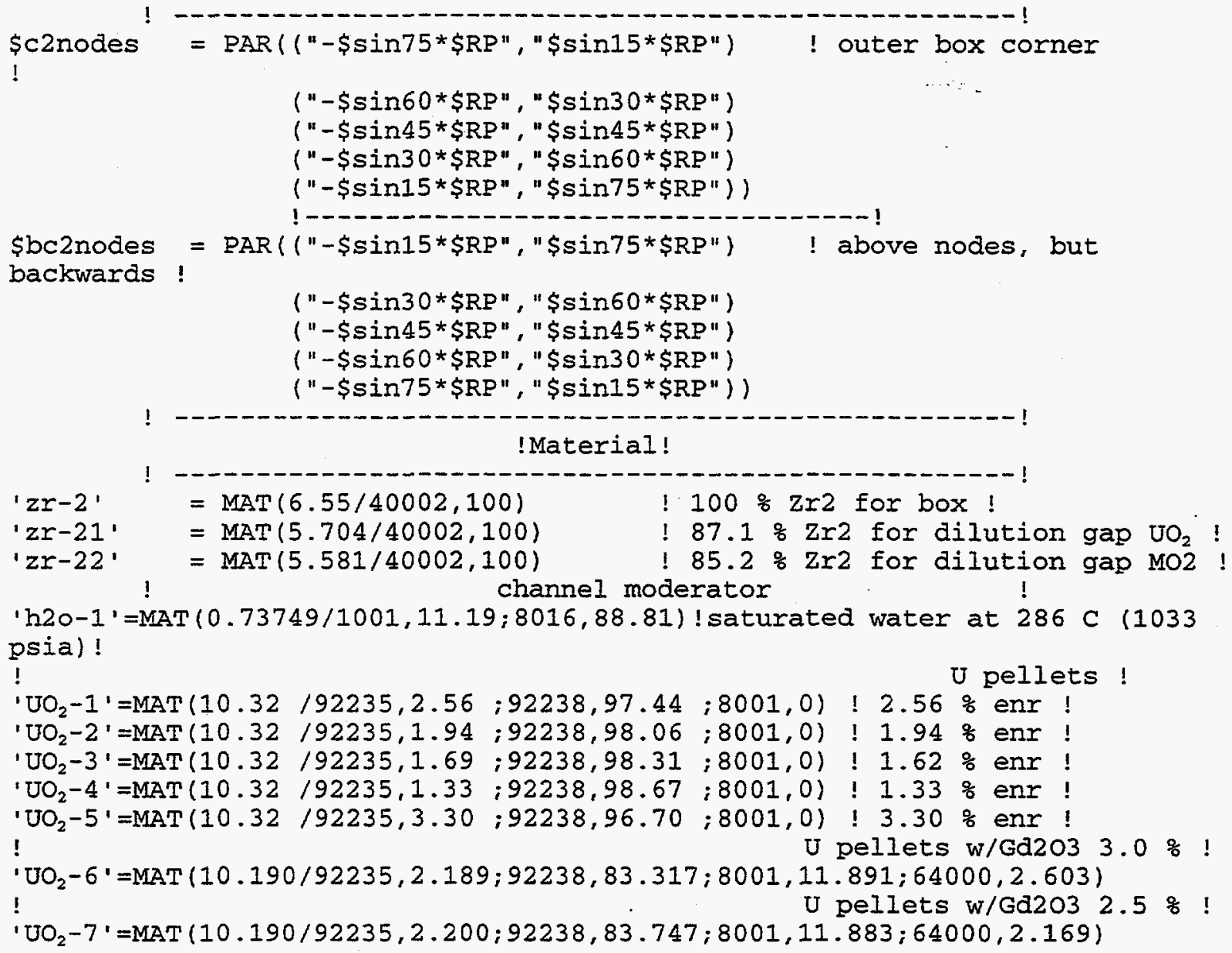

!Pu-1 pellets solid $2.14 \%$ Pu fissile $80 \%$ fissile Pu nominal (80.13\% real)!

$'$ Pu-1' =MAT $(9.890 / 92235,0.6177 ; 92238,85.1804 ; 8001,11.8451$;

$94238,0.0059 ; 94239,1.7832 ; 94240,0.4358 ; 94241,0.1053 ; 94242,0.0266)$

!Pu-2 pellets solid $3.52 \%$ Pu fissile $90 \%$ fissile Pu nominal (89.54\% real)!

'Pu-2'=MAT ( $9.890 / 92235,0.6099 ; 92238,84.1011 ; 8001,11.8446$;

$94238,0.0041 ; 94239,3.0021 ; 94240,0.3465 ; 94241,0.0820 ; 94242,0.0096)$

!Pu-3 pellets hollow $2.34 \%$ Pu fissile $80 \%$ fissile Pu nominal ( $80.13 \%$ real)! ! Dilute density !

$' P u-3 '=\operatorname{MAT}(8.940 / 92235,0.6163 ; 92238,84.9791 ; 8001,11.8449$;

$94238,0.0064 ; 94239,1.9367 ; 94240,0.4733 ; 94241,0.1144 ; 94242,0.0289)$

!Pu-4 pellets hollow $3.62 \%$ Pu fissile $90 \%$ fissile Pu nominal (89.54\% real)! ! Dilute density !

$'$ Pu-4' $=\operatorname{MAT}(8.940 / 92235,0.6092 ; 92238,84.0073 ; 8001,11.8445$;

$94238,0.0042 ; 94239,3.0845 ; 94240,0.3560 ; 94241,0.0842 ; 94242,0.0099)$ 


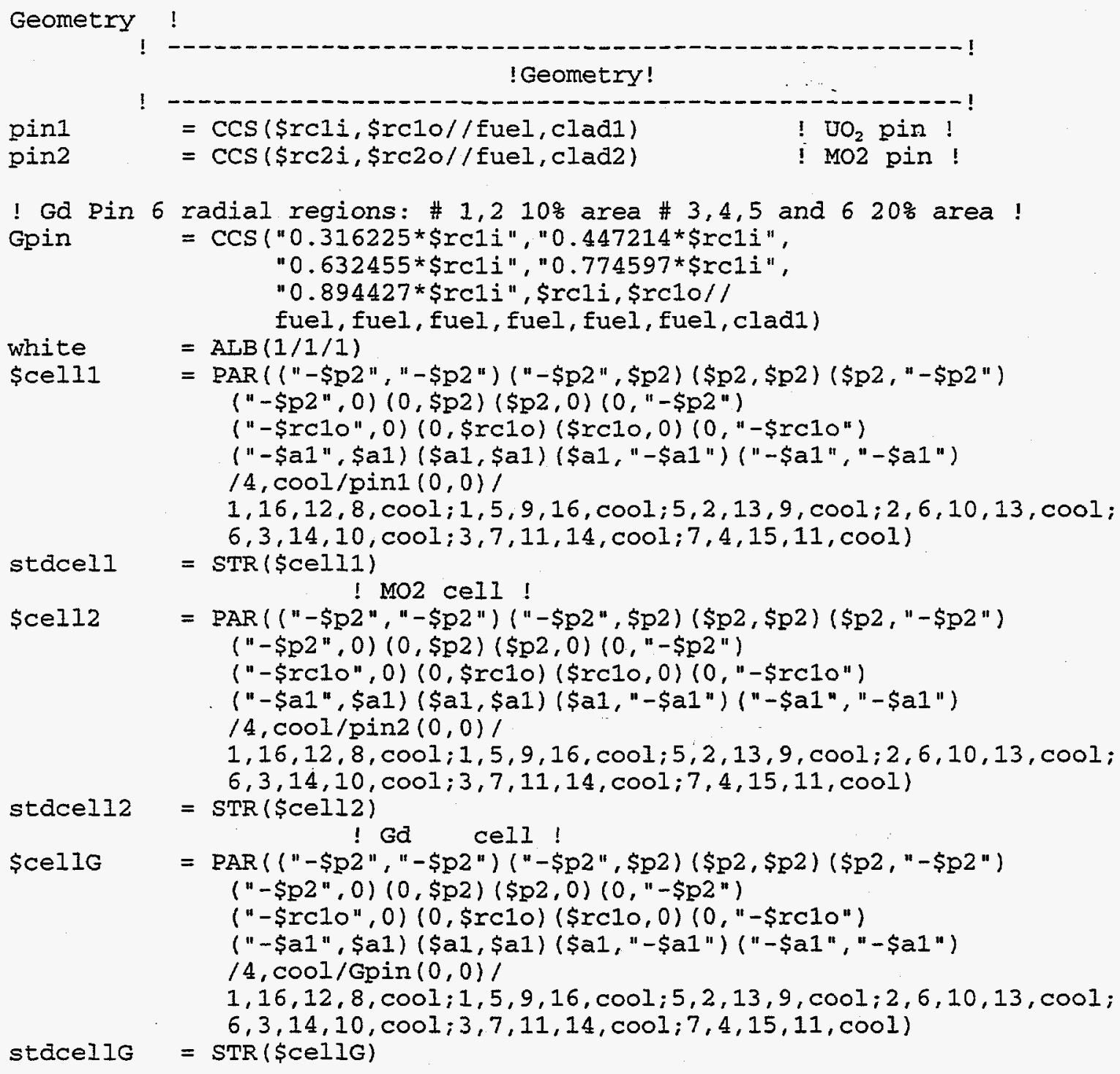

! Gd Pin 6 radial regions: \# 1,2 10\% area \#3,4,5 and $620 \%$ area ! Gpin

$=\operatorname{CCS}(" 0.316225 * \$ r C 1 i ", " 0.447214$ *\$rC1i", "0.632455*\$rC1i", "0.774597*\$rc1i", "0.894427*\$rc1i", \$rcli, \$rc1o// fuel, fuel, fuel, fuel, fuel, fuel, clad1)

white $=\operatorname{AIB}(1 / 1 / 1)$

\$cell1

$=\operatorname{PAR}(("-\$ \mathrm{p} 2 ", "-\$ \mathrm{p} 2$ ") (" $-\$ \mathrm{p} 2 ", \$ \mathrm{p} 2)(\$ \mathrm{p} 2, \$ \mathrm{p} 2)(\$ \mathrm{p} 2, "-\$ \mathrm{p} 2 ")$

("-\$p2", 0) (0, \$p2) (\$p2,0)(0," $\$ \mathrm{pp} 2 ")$

$("-\$ r c 10 ", 0)(0, \$ r c 10)(\$ r c 10,0)(0, "-\$ r c 10 ")$

("-\$a1", \$a1) (\$a1, \$a1) (\$a1, "-\$a1")("-\$a1", "-\$a1")

$14, \operatorname{cool} / \operatorname{pin} 1(0,0) /$

$1,16,12,8, \operatorname{cool} ; 1,5,9,16, \operatorname{cool} ; 5,2,13,9, \operatorname{cool} ; 2,6,10,13$, cool;

stdcel1

$6,3,14,10, \operatorname{cool} ; 3,7,11,14, \operatorname{cool} ; 7,4,15,11, \operatorname{coo} 1)$

$\$ \operatorname{cel} 12$

$=\operatorname{STR}(\$ \operatorname{cel} 11)$ ! MO2 cell! 


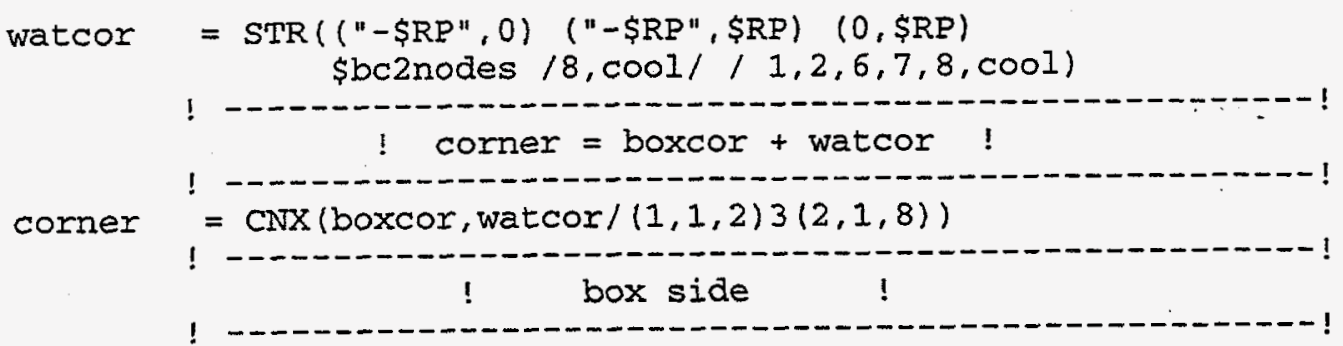

boxside $=\operatorname{STR}((0,0)(0, " 12 * \$ p 2 ")(\$ b o x, " 12 * \$ p 2 ")(\$ b o x, 0)(0, \$ p 2)(0, " 2 * \$ p 2 ")$

$(0, " 3 * \$ p 2 ") \quad(0, " 4 * \$ p 2 ") \quad(0, " 5 * \$ p 2 ") \quad(0, " 6 * \$ p 2 ")$

$(0,7 * \$ p 2 ")(0, " 8 * \$ p 2 ")(0, " 9 * \$ p 2 ")(0, " 10 * \$ s p 2 ")(0, " 11 * \$ \operatorname{sp} 2 ")$

(\$box, "11*\$sp2") (\$box, "10*\$sp2")

$(\$ b o x, " 9 * \$ p 2 ") \quad(\$ b o x, " 8 * \$ p 2 ") \quad(\$ b o x, " 7 * \$ p 2 ")$

(\$box, "6*\$p2") (\$box, "5*\$p2") (\$box, "4*\$p2")

(\$box, "3*\$p2") (\$box, "2*\$p2") (\$box, \$p2)

/4,zrbox/ / 1,5,26,4, zrbox; 5,6,25,26, zrbox; 6,7,24,25, zrbox;

$7,8,23,24$, zrbox; 8,9,22,23, zrbox; 9, 10,21,22, zrbox;

10,11,20,21, zrbox; 11,12,19,20, zrbox; 12,13,18,19, zrbox;

$13,14,17,18$, zrbox; $14,15,16,17$, zrbox)

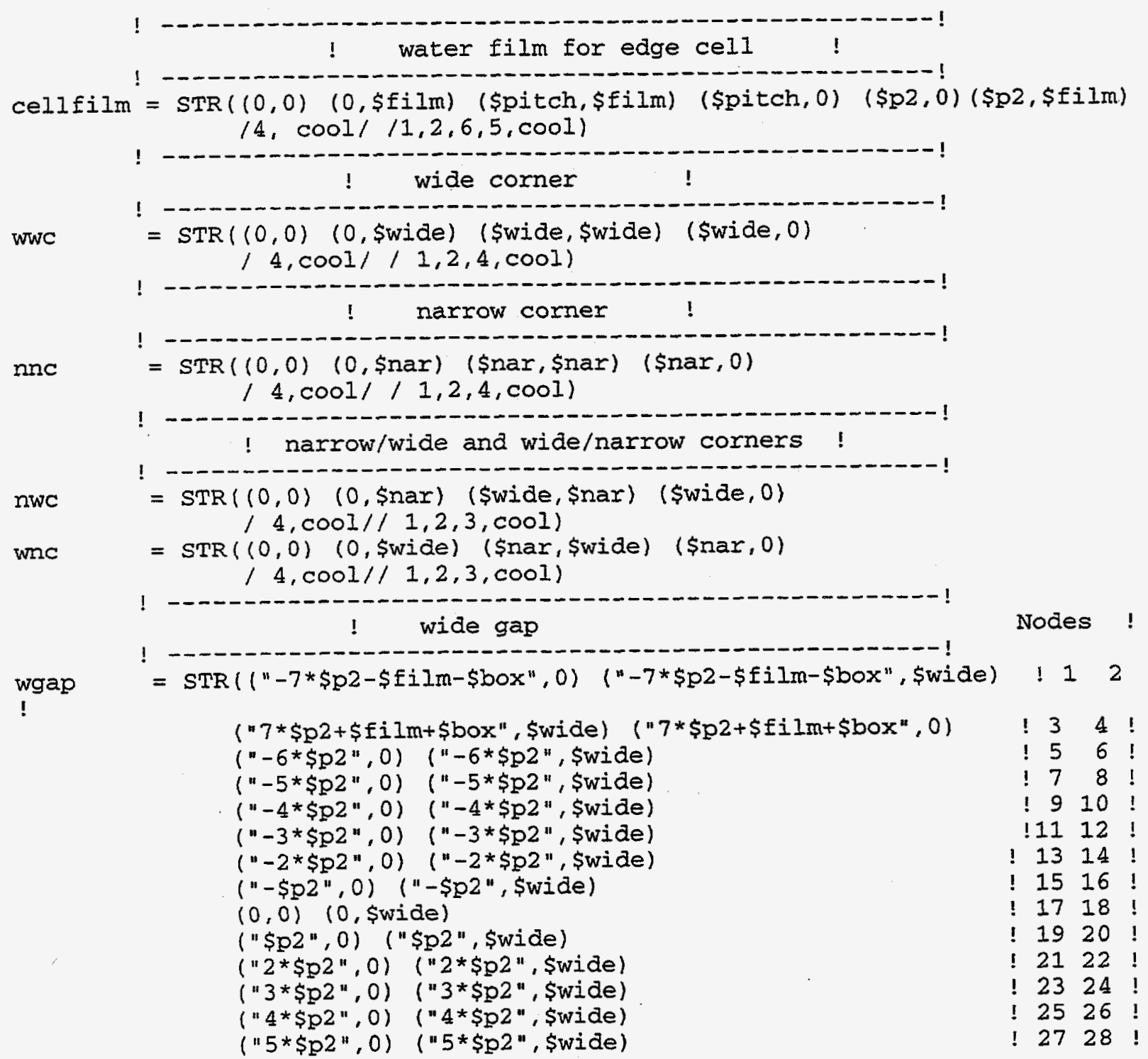


$(" 6 * \$ p 2 ", 0) \quad(" 6 * \$ p 2 ", \$$ wide)

$2930 !$

$/ 4$, cool/ $/ 1,2,6,5$, cool; $5,6,8,7$, cool; $7,8,10,9$, cool;

$9,10,12,11, \mathrm{cool} ; 11,12,14,13, \mathrm{cool} ; 13,14,16,15, \mathrm{cool} ;$

$15,16,18,17, \mathrm{cool} ; 17,18,20,19, \mathrm{cool} ; 19,20,22,21, \mathrm{cool}$;

$21,22,24,23, \mathrm{cool} ; 23,24,26,25, \mathrm{cool} ;$

$25,26,28,27, \mathrm{co0} 1 ; 27,28,30,29, \mathrm{cool})$

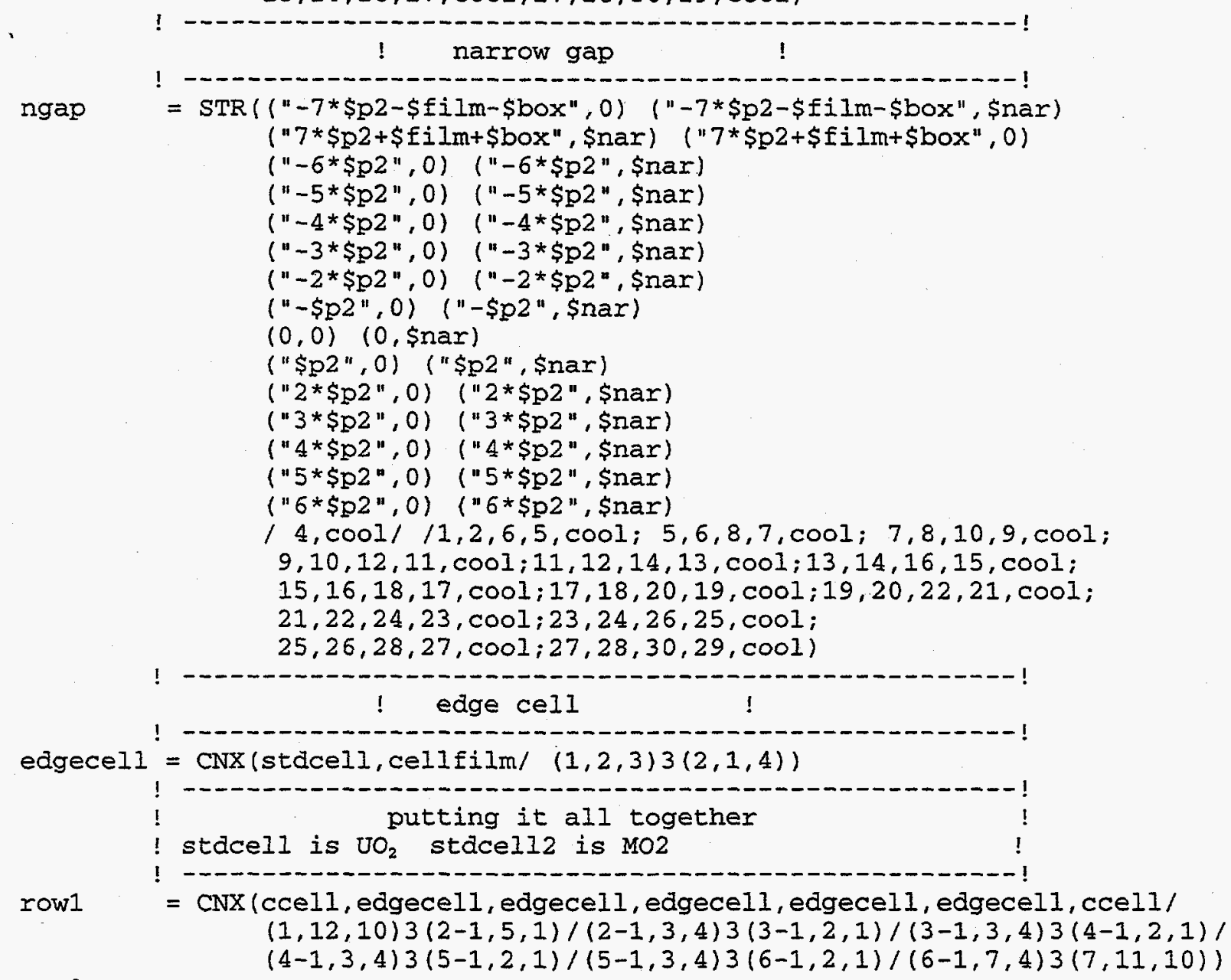

row2 =

CNX (edgecell, stdcellG, stdcel12, stdcell2, stdcellG, stdcell, edgecell/

$(1-1,4,1) 3(2,2,1) /(2,3,4) 3(3,2,1) /(3,3,4) 3(4,2,1) /$

$(4,3,4) 3(5,2,1) /(5,3,4) 3(6,2,1) /(6,3,4) 3(7-1,1,4))$

row3 =

CNX (edgecell, stdcell2, stdcellG, stdcell2, stdcell2, stdcell, edgecell)

$(1-1,4,1) 3(2,2,1) /(2,3,4) 3(3,2,1) /(3,3,4) 3(4,2,1) /$

row4 =

$(4,3,4) 3(5,2,1) /(5,3,4) 3(6,2,1) /(6,3,4) 3(7-1,1,4))$

CNX (edgecel1, stacel12, stacel12, stdcell, stacell2, stacel1, edgecell/ $(1-1,4,1) 3(2,2,1) /(2,3,4) 3(3,2,1) /(3,3,4) 3(4,2,1) /$

$(4,3,4) 3(5,2,1) /(5,3,4) 3(6,2,1) /(6,3,4) 3(7-1,1,4))$

row5 =

CNX (edgecell, stacellG, stdcell2, stacell2, stdcellG, stdcell, edgecell/

$(1-1,4,1) 3(2,2,1) /(2,3,4) 3(3,2,1) /(3,3,4) 3(4,2,1) /$

$(4,3,4) 3(5,2,1) /(5,3,4) 3(6,2,1) /(6,3,4) 3(7-1,1,4))$

row6 = CNX(edgecell, stdcell, stdcell, stdcell, stdcell, stacell, edgecell/ $(1-1,4,1) 3(2,2,1) /(2,3,4) 3(3,2,1) /(3,3,4) 3(4,2,1) /$

$(4,3,4) 3(5,2,1) /(5,3,4) 3(6,2,1) /(6,3,4) 3(7-1,1,4))$

row7 = CNX (cceli, edgecell, edgecell, edgecell, edgecell, edgecell, ccell)

$(1,10,11) 3(2-1,4,7) /(2-1,1,2) 3(3-1,4,3) /(3-1,1,2) 3(4-1,4,3) /$ 
$(4-1,1,2) 3(5-1,4,3) /(5-1,1,2) 3(6-1,4,3) /(6-1,1,5) 3(7,10,12))$

assm $=\operatorname{CNX}($ row1, row2, row3, row4, row5, row6, row7) $(1-2-1,4,1) 3(2-2,3,2)$ )

$(2-2,4,1) 3(3-2,3,2) /(3-2,4,1) 3(4-2,3,2) /(4-2,4,1) 3(5-2,3,2) /$

$(5-2,4,1) 3(6-2,3,2) /(6-2,4,1) 3(7-2-1,1,4))$

square = CNX (corner, boxside, corner, boxside, corner, boxside, corner, boxside/ $(1-1,7,8) 3(2,1,4) /(2,2,3) 3(3-1,1,14) /(3-1,7,8) 3(4,1,4) /$

$(4,2,3) 3(5-1,1,14) /(5-1,7,8) 3(6,1,4) /(6,2,3) 3(7-1,1,14) /$

$(7-1,7,8) 3(8,1,4))$

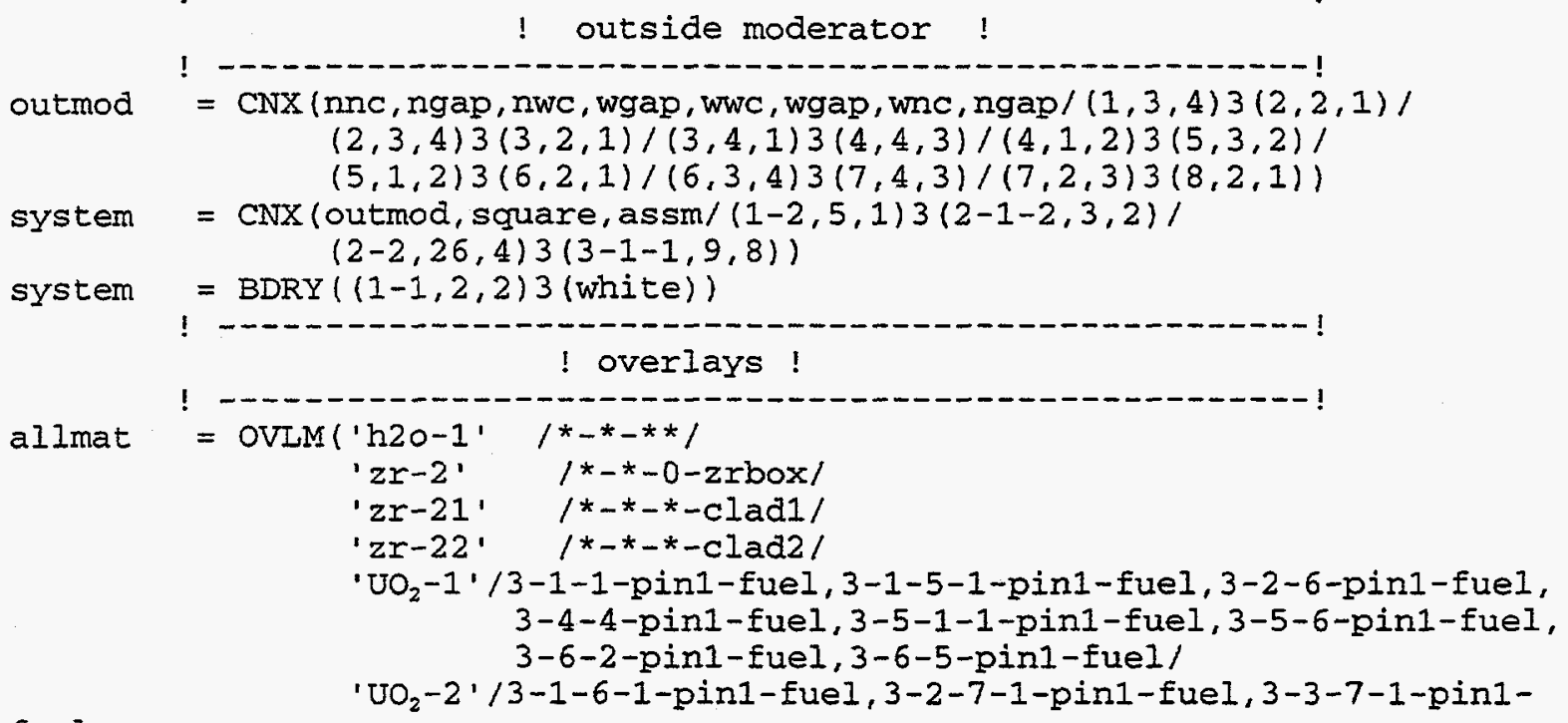

fuel,

3-4-7-1-pin1-fuel, 3-6-1-1-pin1-fuel, 3-6-6-pin1-

fuel,

fuel/

3-7-2-1-pin1-fuel, 3-7-3-1-pin1-fuel , 3-7-4-1-pin1-

fuel/

' $\mathrm{UO}_{2}-3$ ' /3-1-7-pin1-fuel, 3-5-7-1-pin1-fuel, 3-6-7-1-pin1-fuel, 3-7-1-pin1-fuel, 3-7-5-1-pin1-fuel, 3-7-6-1-pin1-

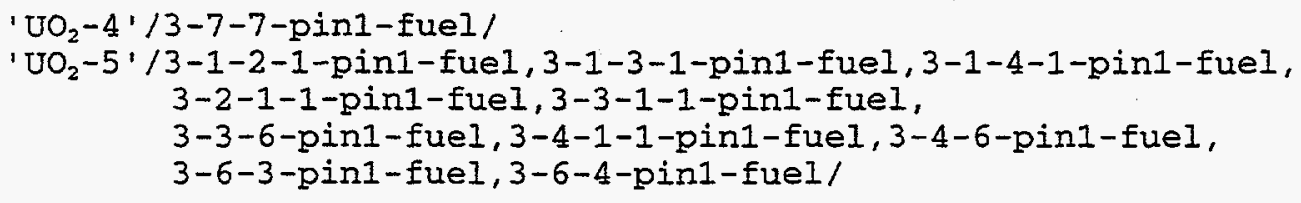

! Gd Pins !

' $\mathrm{UO}_{2}-6$ ' /3-2-5-Gpin-fuel, 3-3-3-Gpin-fuel, 3-5-2-Gpin-fuel, 3-5-5-Gpin-fuel/

! Pu Pins ! ' $\mathrm{UO}_{2}-7 \cdot / 3-2-2-\mathrm{Gpin-fuel/}$

'Pu-1:/3-3-5-pin2-fuel, 3-5-3-pin2-fuel/

' $\mathrm{Pu}-2$ '/3-2-3-pin2-fuel, 3-3-2-pin2-fuel, 3-3-4-pin2-fuel/

' Pu-3:/3-4-5-pin2-fuel, 3-5-4-pin2-fuel/

' Pu-4 '/3-2-4-pin2-fuel, 3-4-2-pin2-fuel, 3-4-3-pin2-fuel)

! Nov 3,97 Twater $=286 \mathrm{C}=559 \mathrm{~K}$, Tfuel=560 $\mathrm{C}=833 \mathrm{~K}$, Tcladl=Average of two!

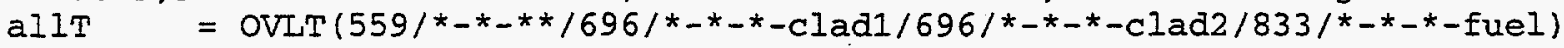

allD = OVLD $\left(1.0 / *_{-} *_{-* *}\right)$

mos $\quad=$ OVSM (allmat)

dos $\quad=$ OVSD (aIID)

tos $\quad=$ OVST (allT)

st $\quad$ Cycle 2 Burnup: July 21,1

Path = PATH $(/$ (st), 11722/12)

Jan $2.1976: 531$ days !
$! 22.07$ Mw $/$ ton initial !
! $11722 / 22.07=531$ days.




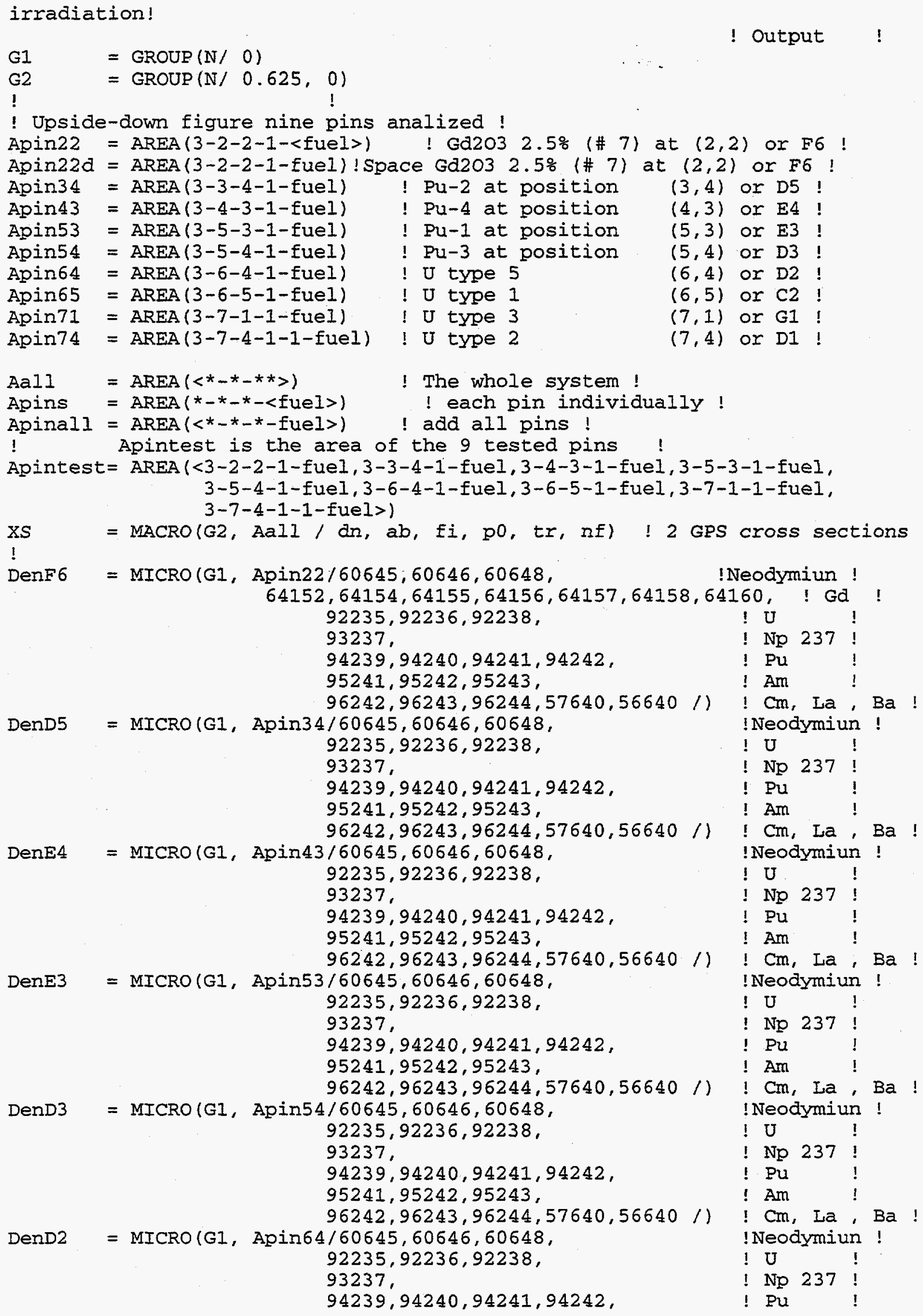




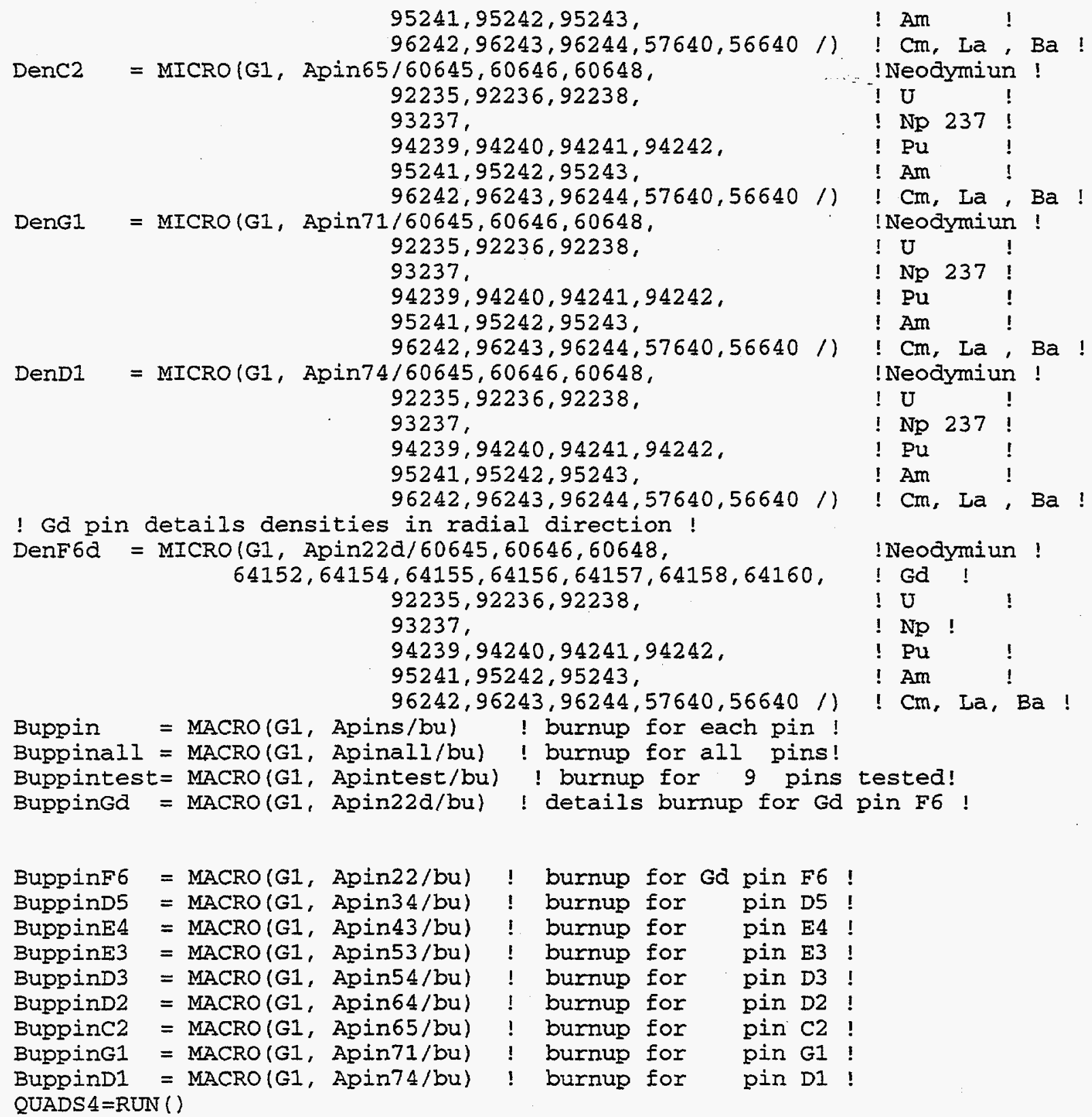




\section{APPENDIX D. MEASURED AND CALCULATED VALUES OF ISOTOPICS, RELATIVE PIN POWER, AND BURNUP BY PIN}

Table D.1. Gadolinium isotopic distributions at end of cycle $2^{a}$

\begin{tabular}{cccccc}
\hline \multicolumn{7}{c}{ Pin burnup $=7179 \mathrm{MWd} / \mathrm{t}$} \\
Isotope & $\begin{array}{c}\text { Measured } \\
\text { at. \% }\end{array}$ & $\begin{array}{c}\text { Measurement } \\
\text { error \% }\end{array}$ & $\begin{array}{c}\text { Calculated atom density } \\
\text { (1/barn.cm) }\end{array}$ & $\begin{array}{c}\text { Calculated } \\
\text { relative at. \% }\end{array}$ & C/M \\
\hline${ }^{152} \mathrm{Gd}$ & 0.1700 & 11.00 & $1.3532 \mathrm{E}-06$ & 0.19036 & 1.1200 \\
${ }^{154} \mathrm{Gd}$ & 2.1100 & 3.00 & $1.4353 \mathrm{E}-05$ & 2.01912 & 0.9560 \\
${ }^{155} \mathrm{Gd}$ & 0.0225 & 14.00 & $8.4258 \mathrm{E}-08$ & 0.01185 & 0.5267 \\
${ }^{156} \mathrm{Gd}$ & 35.2800 & 0.60 & $2.5660 \mathrm{E}-04$ & 36.09747 & 1.0230 \\
${ }^{157} \mathrm{Gd}$ & 0.0281 & 15.00 & $6.5990 \mathrm{E}-08$ & 0.00928 & 0.3300 \\
${ }^{158} \mathrm{Gd}$ & 40.7100 & 0.50 & $2.7872 \mathrm{E}-04$ & 39.20922 & 0.9630 \\
${ }^{160} \mathrm{Gd}$ & 21.7000 & 0.50 & $1.5976 \mathrm{E}-04$ & 22.47440 & 1.0350 \\
Total & 100 & - & $7.1085 \mathrm{E}-04$ & 100.00000 & - \\
\hline
\end{tabular}

${ }^{a}$ Central assembly GEB-16. Pin F6 characteristics: $\mathrm{UO}_{2}$ type 7, enrichment $2.56 \mathrm{wt} \%, 2.5 \mathrm{wt} \%$ $\mathrm{Gd}_{2} \mathrm{O}_{3}$. 
Table D.2. Pin D3 of GEB-161: Isotopic comparison [Pin description: $\mathrm{Pu}$ type P3, hollow, Pu isotopics $80 \%$ fissile, $\mathrm{Pu}$ enrichment $2.34 \mathrm{wt} \%$ (heavy metals)]

\begin{tabular}{cccccc}
\hline Nuclide & $\begin{array}{c}\text { Measured } \\
\text { value }\end{array}$ & $\begin{array}{c}\text { Measurement } \\
\text { error \% }\end{array}$ & $\begin{array}{c}\text { Calculated atom density } \\
\text { (atoms/barn-cm) }\end{array}$ & $\begin{array}{c}\text { Calculated } \\
\text { normalized value }\end{array}$ & C/M ratio \\
\hline${ }^{235} \mathrm{U}$ & $5.386 \mathrm{E}-03$ & 0.80 & $1.017 \mathrm{E}-04$ & $5.291 \mathrm{E}-03$ & 0.982 \\
${ }^{236} \mathrm{U}$ & $3.911 \mathrm{E}-04$ & 2.00 & $7.288 \mathrm{E}-06$ & $3.792 \mathrm{E}-04$ & 0.969 \\
${ }^{238} \mathrm{U}$ & $9.938 \mathrm{E}-01$ & 0.05 & $1.910 \mathrm{E}-02$ & $9.934 \mathrm{E}-01$ & 1.000 \\
${ }^{237} \mathrm{~Np}$ & $5.534 \mathrm{E}-05$ & 18.00 & $8.110 \mathrm{E}-07$ & $4.219 \mathrm{E}-05$ & 0.762 \\
${ }^{239} \mathrm{Pu}$ & $1.331 \mathrm{E}-02$ & 0.10 & $2.538 \mathrm{E}-04$ & $1.320 \mathrm{E}-02$ & 0.992 \\
${ }^{244} \mathrm{Pu}$ & $7.625 \mathrm{E}-03$ & 0.20 & $1.461 \mathrm{E}-04$ & $7.602 \mathrm{E}-03$ & 0.997 \\
${ }^{241} \mathrm{Pu}$ & $2.601 \mathrm{E}-03$ & 0.50 & $4.970 \mathrm{E}-05$ & $2.585 \mathrm{E}-03$ & 0.994 \\
${ }^{242} \mathrm{Pu}$ & $7.221 \mathrm{E}-04$ & 1.00 & $1.321 \mathrm{E}-05$ & $6.870 \mathrm{E}-04$ & 0.951 \\
${ }^{241} \mathrm{Am}$ & $2.588 \mathrm{E}-04$ & 30.00 & $2.085 \mathrm{E}-06$ & $1.085 \mathrm{E}-04$ & 0.419 \\
${ }^{243} \mathrm{Am}$ & $8.278 \mathrm{E}-05$ & 30.00 & $1.609 \mathrm{E}-06$ & $8.373 \mathrm{E}-05$ & 1.011 \\
${ }^{242} \mathrm{Cm}$ & $7.246 \mathrm{E}-05$ & 12.00 & $2.516 \mathrm{E}-07$ & $1.309 \mathrm{E}-05$ & 0.181 \\
${ }^{243} \mathrm{Cm}+{ }^{244} \mathrm{Cm}$ & $1.494 \mathrm{E}-05$ & 14.00 & $2.392 \mathrm{E}-07$ & $1.245 \mathrm{E}-05$ & 0.833 \\
${ }^{145} \mathrm{Nd}$ & $4.415 \mathrm{E}-04$ & 2.20 & $8.135 \mathrm{E}-06$ & $4.232 \mathrm{E}-04$ & 0.959 \\
${ }^{146} \mathrm{Nd}$ & $3.876 \mathrm{E}-04$ & 2.00 & $7.108 \mathrm{E}-06$ & $3.698 \mathrm{E}-04$ & 0.954 \\
${ }^{148} \mathrm{Nd}$ & $2.438 \mathrm{E}-04$ & 0.70 & $4.518 \mathrm{E}-06$ & $2.351 \mathrm{E}-04$ & 0.964 \\
\hline${ }^{a} \mathrm{~d}$ & & & &
\end{tabular}

${ }^{a}$ atom density ratio to initial ${ }^{238} \mathrm{U}$ atom density.

$b_{\text {atom density ratio to calculated initial }}{ }^{238} \mathrm{U}$ atom density (1.922E-02).

Table D.3. Pin D3 of GEB-161: Pin power comparison

\begin{tabular}{ccccccc}
\hline $\begin{array}{c}\text { Measured normalized } \\
\text { pin power } \\
\text { (avg. of 9 rods =1) }\end{array}$ & $\begin{array}{c}\text { Measurement } \\
\text { error \% }\end{array}$ & $\begin{array}{c}\text { Calculated }{ }^{140} \mathrm{Ba} \\
\text { (atoms/barn.cm) }\end{array}$ & $\begin{array}{c}\text { Calculated } \\
\text { normalized pin } \\
\text { power } \\
\text { (avg. of 9 rods=1) }\end{array}$ & $\begin{array}{c}\text { C/M } \\
\text { ratio }\end{array}$ & (C/M-1)·100 \\
\hline 0.968 & 1.7 & $4.874 \mathrm{E}-07$ & 0.915 & 0.945 & -5.6 \\
\hline
\end{tabular}

Table D.4. Pin D3 of GEB-161: Burnup comparison

\begin{tabular}{cccc}
\hline $\begin{array}{c}\text { Measured pin } \\
\text { burnup MWd/t }\end{array}$ & $\begin{array}{c}\text { Calculated pin } \\
\text { burnup MWd/t }\end{array}$ & C/M ratio & (C/M-1) $\cdot 100$ \\
\hline 13100 & 13089 & 0.999 & -0.1 \\
\hline
\end{tabular}


Table D.5. Pin D5 of GEB-161: Isotopic comparison

[Pin description: Pu type P2, solid, Pu isotopics 90\% fissile, Pu enrichment 3.52 wt \% (heavy metals)]

\begin{tabular}{|c|c|c|c|c|c|}
\hline Nuclide & $\begin{array}{c}\text { Measured } \\
\text { value }^{a} \\
\end{array}$ & $\begin{array}{c}\text { Measurement } \\
\text { error \% } \\
\end{array}$ & $\begin{array}{l}\text { Calculated atom density } \\
\text { (atoms/barn } \cdot \mathrm{cm})^{b}\end{array}$ & $\begin{array}{c}\text { Calculated } \\
\text { normalized value }\end{array}$ & $\mathrm{C} / \mathrm{M}$ ratio \\
\hline${ }^{235} \mathrm{U}$ & $5.772 \mathrm{E}-03$ & 0.80 & $1.227 \mathrm{E}-04$ & $5.828 \mathrm{E}-03$ & 1.010 \\
\hline${ }^{236} \mathrm{U}$ & $3.025 \mathrm{E}-04$ & 2.00 & $6.448 \mathrm{E}-06$ & $3.064 \mathrm{E}-04$ & 1.013 \\
\hline${ }^{238} \mathrm{U}$ & $9.940 \mathrm{E}-01$ & 0.05 & $2.092 \mathrm{E}-02$ & $9.938 \mathrm{E}-01$ & 1.000 \\
\hline${ }^{237} \mathrm{~Np}$ & $5.334 \mathrm{E}-05$ & 18.00 & $8.791 \mathrm{E}-07$ & 4.177E-05 & 0.783 \\
\hline${ }^{239} \mathrm{Pu}$ & $2.425 \mathrm{E}-02$ & 0.10 & $5.087 \mathrm{E}-04$ & $2.417 \mathrm{E}-02$ & 0.997 \\
\hline${ }^{240} \mathrm{Pu}$ & $7.425 \mathrm{E}-03$ & 0.20 & $1.556 \mathrm{E}-04$ & $7.392 E-03$ & 0.996 \\
\hline${ }^{241} \mathrm{Pu}$ & $2.303 \mathrm{E}-03$ & 0.50 & $4.860 \mathrm{E}-05$ & $2.309 \mathrm{E}-03$ & 1.003 \\
\hline${ }^{242} \mathrm{Pu}$ & $3.374 \mathrm{E}-04$ & 1.00 & $6.620 \mathrm{E}-06$ & 3.146E-04 & 0.932 \\
\hline${ }^{241} \mathrm{Am}$ & $2.269 \mathrm{E}-04$ & 30.00 & $2.000 \mathrm{E}-06$ & $9.502 \mathrm{E}-05$ & 0.419 \\
\hline${ }^{243} \mathrm{Am}$ & $3.728 \mathrm{E}-05$ & 30.00 & $7.662 \mathrm{E}-07$ & $3.641 \mathrm{E}-05$ & 0.977 \\
\hline${ }^{242} \mathrm{Cm}$ & $4.260 \mathrm{E}-05$ & 12.00 & $1.720 \mathrm{E}-07$ & $8.173 E-06$ & 0.192 \\
\hline${ }^{243} \mathrm{Cm}+{ }^{244} \mathrm{Cm}$ & $5.589 \mathrm{E}-06$ & 14.00 & $1.020 \mathrm{E}-07$ & $4.846 \mathrm{E}-06$ & 0.867 \\
\hline${ }^{145} \mathrm{Nd}$ & 4.187E-04 & 2.20 & $8.729 \mathrm{E}-06$ & $4.148 \mathrm{E}-04$ & 0.991 \\
\hline${ }^{146} \mathrm{Nd}$ & 3.695E-04 & 2.00 & $7.580 \mathrm{E}-06$ & $3.602 \mathrm{E}-04$ & 0.975 \\
\hline${ }^{148} \mathrm{Nd}$ & 2.332E-04 & 0.70 & $4.848 \mathrm{E}-06$ & $2.303 \mathrm{E}-04$ & 0.988 \\
\hline
\end{tabular}

${ }^{a}$ atom density ratio to initial ${ }^{238} \mathrm{U}$ atom density.

$b$ atom density ratio to calculated initial ${ }^{238} \mathrm{U}$ atom density (2.104E-02).

Table D.6. Pin D5 of GEB-161: Pin power comparison

\begin{tabular}{cccccc}
\hline $\begin{array}{c}\text { Measured normalized } \\
\text { pin power } \\
\text { (avg. of 9 rods =1) }\end{array}$ & $\begin{array}{c}\text { Measurement } \\
\text { error \% }\end{array}$ & $\begin{array}{c}\text { Calculated }{ }^{140} \mathrm{Ba} \\
\text { (atoms/barn } \cdot \mathrm{cm} \text { ) }\end{array}$ & $\begin{array}{c}\text { Calculated } \\
\text { normalized pin } \\
\text { power }\end{array}$ \\
\hline 1.046 & 1.7 & $5.628 \mathrm{E}-07$ & 1.056 & 1.010 & 1.0 \\
\hline
\end{tabular}

Table D.7. Pin D5 of GEB-161: Burnup comparison

\begin{tabular}{cccc}
\hline $\begin{array}{c}\text { Measured pin } \\
\text { burnup MWd/t }\end{array}$ & $\begin{array}{c}\text { Calculated pin } \\
\text { burnup MWd/t }\end{array}$ & C/M ratio & (C/M-1)·100 \\
\hline 12500 & 12831 & 1.027 & 2.7 \\
\hline
\end{tabular}


Table D.8. Pin E3 of GEB-161: Isotopic comparison

[Pin description: Pu type P1, solid, Pu isotopics $80 \%$ fissile, Pu enrichment 2.14 wt \% (heavy metals)]

\begin{tabular}{cccccc}
\hline Nuclide & $\begin{array}{c}\text { Measured } \\
\text { value }^{a}\end{array}$ & $\begin{array}{c}\text { Measurement } \\
\text { error \% }\end{array}$ & $\begin{array}{c}\text { Calculated atom density } \\
\text { (atoms/barn } \cdot \mathbf{c m} \text { ) }\end{array}$ & $\begin{array}{c}\text { Calculated } \\
\text { normalized value }\end{array}$ & C/M ratio \\
\hline${ }^{235} \mathrm{U}$ & $5.311 \mathrm{E}-03$ & 0.80 & $1.142 \mathrm{E}-04$ & $5.356 \mathrm{E}-03$ & 1.008 \\
${ }^{236} \mathrm{U}$ & $3.481 \mathrm{E}-04$ & 2.00 & $7.895 \mathrm{E}-06$ & $3.704 \mathrm{E}-04$ & 1.064 \\
${ }^{238} \mathrm{U}$ & $9.941 \mathrm{E}-01$ & 0.05 & $2.118 \mathrm{E}-02$ & $9.935 \mathrm{E}-01$ & 0.999 \\
${ }^{237} \mathrm{~Np}$ & $\mathrm{NA}$ & 18.00 & $8.876 \mathrm{E}-07$ & $4.164 \mathrm{E}-05$ & NA \\
${ }^{239} \mathrm{Pu}$ & $1.306 \mathrm{E}-02$ & 0.10 & $2.706 \mathrm{E}-04$ & $1.270 \mathrm{E}-02$ & 0.972 \\
${ }^{240} \mathrm{Pu}$ & $6.955 \mathrm{E}-03$ & 0.20 & $1.481 \mathrm{E}-04$ & $6.948 \mathrm{E}-03$ & 0.999 \\
${ }^{241} \mathrm{Pu}$ & $2.371 \mathrm{E}-03$ & 0.50 & $5.077 \mathrm{E}-05$ & $2.382 \mathrm{E}-03$ & 1.005 \\
${ }^{242} \mathrm{Pu}$ & $6.392 \mathrm{E}-04$ & 1.00 & $1.311 \mathrm{E}-05$ & $6.152 \mathrm{E}-04$ & 0.962 \\
${ }^{241} \mathrm{Am}$ & $3.025 \mathrm{E}-04$ & 30.00 & $2.141 \mathrm{E}-06$ & $1.004 \mathrm{E}-04$ & 0.332 \\
${ }^{243} \mathrm{Am}$ & $8.468 \mathrm{E}-05$ & 30.00 & $1.620 \mathrm{E}-06$ & $7.601 \mathrm{E}-05$ & 0.898 \\
${ }^{242} \mathrm{Cm}$ & $7.325 \mathrm{E}-05$ & 12.00 & $2.505 \mathrm{E}-07$ & $1.175 \mathrm{E}-05$ & 0.160 \\
${ }^{243} \mathrm{Cm}+{ }^{244} \mathrm{Cm}$ & $1.489 \mathrm{E}-05$ & 14.00 & $2.414 \mathrm{E}-07$ & $1.133 \mathrm{E}-05$ & 0.761 \\
${ }^{145} \mathrm{Nd}$ & $3.865 \mathrm{E}-04$ & 2.20 & $8.252 \mathrm{E}-06$ & $3.872 \mathrm{E}-04$ & 1.002 \\
${ }^{146} \mathrm{Nd}$ & $3.442 \mathrm{E}-04$ & 2.00 & $7.201 \mathrm{E}-06$ & $3.378 \mathrm{E}-04$ & 0.982 \\
${ }^{148} \mathrm{Nd}$ & $2.160 \mathrm{E}-04$ & 0.70 & $4.570 \mathrm{E}-06$ & $2.144 \mathrm{E}-04$ & 0.993 \\
\hline
\end{tabular}

$a_{\text {atom density ratio to initial }}{ }^{238} \mathrm{U}$ atom density.

${ }^{b}$ atom density ratio to calculated initial ${ }^{238} \mathrm{U}$ atom density (2.131E-02).

Table D.9. Pin E3 of GEB-161: Pin power comparison

\begin{tabular}{cccccc}
\hline $\begin{array}{c}\text { Measured normalized } \\
\text { pin power } \\
\text { (avg. of 9 rods = 1) }\end{array}$ & $\begin{array}{c}\text { Measurement } \\
\text { error \% }\end{array}$ & $\begin{array}{c}\text { Calculated }{ }^{140} \mathrm{Ba} \\
\text { (atoms/barn.cm) }\end{array}$ & $\begin{array}{c}\text { Calculated } \\
\text { normalized pin } \\
\text { power }\end{array}$ \\
\hline 0.954 & 1.7 & avg. of 9 rods =1) & C/M ratio & (C/M-1) $\cdot 100$ \\
\hline
\end{tabular}

Table D.10. Pin E3 of GEB-161: Burnup comparison

\begin{tabular}{cccc}
\hline $\begin{array}{c}\text { Measured pin } \\
\text { burnup MWd/t }\end{array}$ & $\begin{array}{c}\text { Calculated pin } \\
\text { burnup MWd/t }\end{array}$ & C/M ratio & (C/M-1)·100 \\
\hline 11600 & 11958 & 1.031 & 3.1 \\
\hline
\end{tabular}


Table D.11. Pin E4 of GEB-161: Isotopic comparison

[Pin description: Pu type P4, hollow, Pu isotopics 90\% fissile, Pu enrichment $3.62 \mathrm{wt} \%$ (heavy metals)]

\begin{tabular}{cccccc}
\hline Nuclide & $\begin{array}{c}\text { Measured } \\
\text { value }^{a}\end{array}$ & $\begin{array}{c}\text { Measurement } \\
\text { error \% }\end{array}$ & $\begin{array}{c}\text { Calculated atom density } \\
\text { (atoms/barn } \cdot c m\end{array}$ & $\begin{array}{c}\text { Calculated } \\
\text { normalized value }\end{array}$ & C/M ratio \\
\hline${ }^{235} \mathrm{U}$ & $5.733 \mathrm{E}-03$ & 0.80 & $1.099 \mathrm{E}-04$ & $5.785 \mathrm{E}-03$ & 1.009 \\
${ }^{236} \mathrm{U}$ & $3.104 \mathrm{E}-04$ & 2.00 & $5.948 \mathrm{E}-06$ & $3.131 \mathrm{E}-04$ & 1.009 \\
${ }^{238} \mathrm{U}$ & $9.934 \mathrm{E}-01$ & 0.05 & $1.888 \mathrm{E}-02$ & $9.938 \mathrm{E}-01$ & 1.000 \\
${ }^{237} \mathrm{~Np}$ & $5.135 \mathrm{E}-05$ & 18.00 & $7.950 \mathrm{E}-07$ & $4.184 \mathrm{E}-05$ & 0.815 \\
${ }^{239} \mathrm{Pu}$ & $2.475 \mathrm{E}-02$ & 0.10 & $4.626 \mathrm{E}-04$ & $2.435 \mathrm{E}-02$ & 0.984 \\
${ }^{240} \mathrm{Pu}$ & $7.703 \mathrm{E}-03$ & 0.20 & $1.462 \mathrm{E}-04$ & $7.693 \mathrm{E}-03$ & 0.999 \\
${ }^{241} \mathrm{Pu}$ & $2.413 \mathrm{E}-03$ & 0.50 & $4.607 \mathrm{E}-05$ & $2.425 \mathrm{E}-03$ & 1.005 \\
${ }^{242} \mathrm{Pu}$ & $3.570 \mathrm{E}-04$ & 1.00 & $6.398 \mathrm{E}-06$ & $3.367 \mathrm{E}-04$ & 0.943 \\
${ }^{241} \mathrm{Am}$ & $2.946 \mathrm{E}-04$ & 30.00 & $1.875 \mathrm{E}-06$ & $9.871 \mathrm{E}-05$ & 0.335 \\
${ }^{243} \mathrm{Am}$ & $4.149 \mathrm{E}-05$ & 35.00 & $7.351 \mathrm{E}-07$ & $3.869 \mathrm{E}-05$ & 0.932 \\
${ }^{242} \mathrm{Cm}$ & $4.857 \mathrm{E}-05$ & 12.00 & $1.665 \mathrm{E}-07$ & $8.764 \mathrm{E}-06$ & 0.180 \\
${ }^{243} \mathrm{Cm}+{ }^{244} \mathrm{Cm}$ & $6.373 \mathrm{E}-06$ & 14.00 & $9.807 \mathrm{E}-08$ & $5.162 \mathrm{E}-06$ & 0.810 \\
${ }^{145} \mathrm{Nd}$ & $4.566 \mathrm{E}-04$ & 2.20 & $8.308 \mathrm{E}-06$ & $4.373 \mathrm{E}-04$ & 0.958 \\
${ }^{146} \mathrm{Nd}$ & $3.946 \mathrm{E}-04$ & 2.00 & $7.221 \mathrm{E}-06$ & $3.800 \mathrm{E}-04$ & 0.963 \\
${ }^{148} \mathrm{Nd}$ & $2.492 \mathrm{E}-04$ & 0.70 & $4.620 \mathrm{E}-06$ & $2.431 \mathrm{E}-04$ & 0.976 \\
\hline
\end{tabular}

${ }^{a}$ atom density ratio to initial ${ }^{238} \mathrm{U}$ atom density.

$b_{\text {atom density ratio to calculated initial }}{ }^{238} \mathrm{U}$ atom density (1.900E-02).

Table D.12. Pin E4 of GEB-161: Pin power comparison

\begin{tabular}{cccccc}
\hline $\begin{array}{c}\text { Measured normalized } \\
\text { pin power } \\
\text { (avg. of 9 rods=1) }\end{array}$ & $\begin{array}{c}\text { Measurement } \\
\text { error \% }\end{array}$ & $\begin{array}{c}\text { Calculated }{ }^{\mathbf{1 4 0}} \text { Ba } \\
\text { (atoms/barn } \cdot \mathbf{c m} \text { ) }\end{array}$ & $\begin{array}{c}\text { Calculated } \\
\text { normalized pin } \\
\text { power }\end{array}$ \\
(avg. of 9 rods = 1) & C/M ratio & (C/M-1) $\cdot 100$ \\
\hline 1.033 & 1.7 & $5.336 \mathrm{E}-07$ & 1.001 & 0.969 & -3.1 \\
\hline
\end{tabular}

Table D.13. Pin E4 of GEB-161: Burnup comparison

\begin{tabular}{cccc}
\hline $\begin{array}{c}\text { Measured pin } \\
\text { burnup MWd/t }\end{array}$ & $\begin{array}{c}\text { Calculated pin } \\
\text { burnup MWd/t }\end{array}$ & C/M ratio & (C/M-1):100 \\
\hline 13400 & 13533 & 1.010 & 1.0 \\
\hline
\end{tabular}


Table D.14. Pin C2 of GEB-161: Isotopic comparison

(Pin description: $\mathrm{UO}_{2}$ type 1, enrichment $2.56 \mathrm{wt} \%$ )

\begin{tabular}{cccccc}
\hline Nuclide & $\begin{array}{c}\text { Measured } \\
\text { value }\end{array}$ & $\begin{array}{c}\text { Measurement } \\
\text { error } \%\end{array}$ & $\begin{array}{c}\text { Calculated atom density } \\
\text { (atoms/barn-cm) }\end{array}$ & $\begin{array}{c}\text { Calculated } \\
\text { normalized value }\end{array}$ & C/M ratio \\
\hline${ }^{235} \mathrm{U}$ & $1.527 \mathrm{E}-02$ & 0.80 & $3.433 \mathrm{E}-04$ & $1.531 \mathrm{E}-02$ & 1.002 \\
${ }^{236} \mathrm{U}$ & $2.083 \mathrm{E}-03$ & 2.00 & $4.220 \mathrm{E}-05$ & $1.882 \mathrm{E}-03$ & 0.903 \\
${ }^{238} \mathrm{U}$ & $9.923 \mathrm{E}-01$ & 0.05 & $2.227 \mathrm{E}-02$ & $9.927 \mathrm{E}-01$ & 1.000 \\
${ }^{237} \mathrm{~Np}$ & $8.274 \mathrm{E}-05$ & 18.00 & $1.630 \mathrm{E}-06$ & $7.269 \mathrm{E}-05$ & 0.879 \\
${ }^{239} \mathrm{Pu}$ & $3.328 \mathrm{E}-03$ & 0.10 & $7.018 \mathrm{E}-05$ & $3.129 \mathrm{E}-03$ & 0.940 \\
${ }^{240} \mathrm{Pu}$ & $8.066 \mathrm{E}-04$ & 0.30 & $1.735 \mathrm{E}-05$ & $7.737 \mathrm{E}-04$ & 0.959 \\
${ }^{241} \mathrm{Pu}$ & $2.828 \mathrm{E}-04$ & 0.50 & $5.363 \mathrm{E}-06$ & $2.391 \mathrm{E}-04$ & 0.846 \\
${ }^{242} \mathrm{Pu}$ & $3.874 \mathrm{E}-05$ & 1.40 & $6.850 \mathrm{E}-07$ & $3.054 \mathrm{E}-05$ & 0.788 \\
${ }^{241} \mathrm{Am}$ & $8.923 \mathrm{E}-06$ & $-{ }^{c}$ & $1.003 \mathrm{E}-07$ & $4.470 \mathrm{E}-06$ & 0.501 \\
${ }^{243} \mathrm{Am}$ & $2.510 \mathrm{E}-06$ & $-{ }^{c}$ & $3.748 \mathrm{E}-08$ & $1.671 \mathrm{E}-06$ & 0.666 \\
${ }^{242} \mathrm{Cm}$ & $8.802 \mathrm{E}-07$ & 12.00 & $1.257 \mathrm{E}-08$ & $5.605 \mathrm{E}-07$ & 0.637 \\
${ }^{243} \mathrm{Cm}+{ }^{244} \mathrm{Cm}$ & $2.091 \mathrm{E}-07$ & 1.40 & $2.789 \mathrm{E}-09$ & $1.244 \mathrm{E}-07$ & 0.595 \\
${ }^{145} \mathrm{Nd}$ & $4.411 \mathrm{E}-04$ & 2.20 & $1.001 \mathrm{E}-05$ & $4.465 \mathrm{E}-04$ & 1.012 \\
${ }^{146} \mathrm{Nd}$ & $3.740 \mathrm{E}-04$ & 2.00 & $8.447 \mathrm{E}-06$ & $3.766 \mathrm{E}-04$ & 1.007 \\
${ }^{148} \mathrm{Nd}$ & $2.107 \mathrm{E}-04$ & 0.70 & $4.747 \mathrm{E}-06$ & $2.117 \mathrm{E}-04$ & 1.005 \\
\hline
\end{tabular}

${ }^{a}$ atom density ratio to initial ${ }^{238} \mathrm{U}$ atom density.

$b$ atom density ratio to calculated initial ${ }^{238} \mathrm{U}$ atom density (2.243E-02).

${ }^{c}$ Quoted measurement error so high that measurement judged to have little value.

Table D.15. Pin C2 of GEB-161: Pin power comparison

\begin{tabular}{cccccc}
\hline $\begin{array}{c}\text { Measured normalized } \\
\text { pin power } \\
\text { (avg. of 9 rods =1) }\end{array}$ & $\begin{array}{c}\text { Measurement } \\
\text { error \% }\end{array}$ & $\begin{array}{c}\text { Calculated }{ }^{140} \mathrm{Ba} \\
\text { (atoms/barn } \cdot \mathrm{cm} \text { ) }\end{array}$ & $\begin{array}{c}\text { Calculated } \\
\text { normalized pin } \\
\text { power }\end{array}$ \\
\hline (avg. of 9 rods=1) & C/M ratio & (C/M-1) $\cdot 100$ \\
\hline 1.022 & 1.7 & $5.496 \mathrm{E}-07$ & 1.031 & 1.009 & 0.9 \\
\hline
\end{tabular}

Table D.16. Pin C2 of GEB-161: Burnup comparison

\begin{tabular}{cccc}
\hline $\begin{array}{c}\text { Measured pin } \\
\text { burnup Mwd/t }\end{array}$ & $\begin{array}{c}\text { Calculated pin } \\
\text { burnup MWd/t }\end{array}$ & C/M ratio & (C/M-1)·100 \\
\hline 11450 & 11556 & 1.009 & 0.9 \\
\hline
\end{tabular}


Table D.17. Pin D1 of GEB-161: Isotopic comparison

(Pin description: $\mathrm{UO}_{2}$ type 2, enrichment $1.94 \mathrm{wt} \%$ )

\begin{tabular}{cccccc}
\hline Nuclide & $\begin{array}{c}\text { Measured } \\
\text { value }^{a}\end{array}$ & $\begin{array}{c}\text { Measurement } \\
\text { error \% }\end{array}$ & $\begin{array}{c}\text { Calculated atom density } \\
\text { (atoms/barn-cm) }^{b}\end{array}$ & $\begin{array}{c}\text { Calculated } \\
\text { normalized value }\end{array}$ & C/M ratio \\
\hline${ }^{235} \mathrm{U}$ & $9.808 \mathrm{E}-03$ & 0.80 & $2.159 \mathrm{E}-04$ & $9.563 \mathrm{E}-03$ & 0.975 \\
${ }^{236} \mathrm{U}$ & $1.867 \mathrm{E}-03$ & 2.00 & $3.793 \mathrm{E}-05$ & $1.681 \mathrm{E}-03$ & 0.900 \\
${ }^{238} \mathrm{U}$ & $9.908 \mathrm{E}-01$ & 0.05 & $2.239 \mathrm{E}-02$ & $9.918 \mathrm{E}-01$ & 1.001 \\
${ }^{237} \mathrm{~Np}$ & $9.229 \mathrm{E}-05$ & 18.00 & $1.585 \mathrm{E}-06$ & $7.022 \mathrm{E}-05$ & 0.761 \\
${ }^{239} \mathrm{Pu}$ & $3.276 \mathrm{E}-03$ & 0.10 & $6.820 \mathrm{E}-05$ & $3.022 \mathrm{E}-03$ & 0.922 \\
${ }^{240} \mathrm{Pu}$ & $9.999 \mathrm{E}-04$ & 0.30 & $2.171 \mathrm{E}-05$ & $9.620 \mathrm{E}-04$ & 0.962 \\
${ }^{241} \mathrm{Pu}$ & $3.563 \mathrm{E}-04$ & 0.50 & $6.829 \mathrm{E}-06$ & $3.026 \mathrm{E}-04$ & 0.849 \\
${ }^{242} \mathrm{Pu}$ & $6.640 \mathrm{E}-05$ & 1.40 & $1.204 \mathrm{E}-06$ & $5.333 \mathrm{E}-05$ & 0.803 \\
${ }^{241} \mathrm{Am}$ & $3.023 \mathrm{E}-06$ & $-c$ & $1.278 \mathrm{E}-07$ & $5.660 \mathrm{E}-06$ & 1.872 \\
${ }^{243} \mathrm{Am}$ & $3.748 \mathrm{E}-06$ & $-{ }^{c}$ & $7.224 \mathrm{E}-08$ & $3.200 \mathrm{E}-06$ & 0.854 \\
${ }^{242} \mathrm{Cm}$ & $1.116 \mathrm{E}-06$ & 12.00 & $2.051 \mathrm{E}-08$ & $9.087 \mathrm{E}-07$ & 0.814 \\
${ }^{243} \mathrm{Cm}+{ }^{244} \mathrm{Cm}$ & $3.525 \mathrm{E}-07$ & 14.00 & $6.053 \mathrm{E}-09$ & $2.682 \mathrm{E}-07$ & 0.761 \\
${ }^{145} \mathrm{Nd}$ & $4.453 \mathrm{E}-04$ & 2.20 & $9.946 \mathrm{E}-06$ & $4.407 \mathrm{E}-04$ & 0.990 \\
${ }^{146} \mathrm{Nd}$ & $3.971 \mathrm{E}-04$ & 2.00 & $8.550 \mathrm{E}-06$ & $3.788 \mathrm{E}-04$ & 0.954 \\
${ }^{148} \mathrm{Nd}$ & $2.213 \mathrm{E}-04$ & 0.70 & $4.834 \mathrm{E}-06$ & $2.141 \mathrm{E}-04$ & 0.968 \\
\hline
\end{tabular}

${ }^{a}$ atom density ratio to initial ${ }^{238} \mathrm{U}$ atom density.

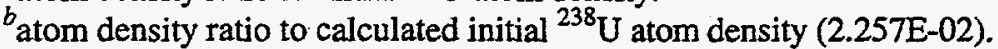

${ }^{c}$ Quoted measurement error so high that measurement judged to have little value.

Table D.18. Pin D1 of GEB-161: Pin power comparison

\begin{tabular}{ccccccc}
\hline $\begin{array}{c}\text { Measured normalized } \\
\text { pin power } \\
\text { (avg. of 9 rods =1) }\end{array}$ & $\begin{array}{c}\text { Measurement } \\
\text { error \% }\end{array}$ & $\begin{array}{c}\text { Calculated }{ }^{140} \mathrm{Ba} \\
\text { (atoms/barn.cm) }\end{array}$ & $\begin{array}{c}\text { Calculated } \\
\text { normalized pin } \\
\text { power }\end{array}$ \\
\hline 0.995 & 1.7 & $5.303 \mathrm{E}-07$ & 0.9951 & 1.000 & 0.0 \\
\hline
\end{tabular}

Table D.19. Pin D1 of GEB-161: Burnup comparison

\begin{tabular}{cccc}
\hline $\begin{array}{c}\text { Measured pin } \\
\text { burnup Mwd/t }\end{array}$ & $\begin{array}{c}\text { Calculated pin } \\
\text { burnup MWd/t }\end{array}$ & C/M ratio & (C/M-1):100 \\
\hline 12100 & 11754 & 0.971 & -2.9 \\
\hline
\end{tabular}


Table D.20. Pin D2 of GEB-161: Isotopic comparison

(Pin description: $\mathrm{UO}_{2}$ type 5, enrichment $3.30 \mathrm{wt} \%$ )

\begin{tabular}{cccccc}
\hline Nuclide & $\begin{array}{c}\text { Measured } \\
\text { value }^{a}\end{array}$ & $\begin{array}{c}\text { Measurement } \\
\text { error \% }\end{array}$ & $\begin{array}{c}\text { Calculated atom density } \\
\text { (atoms/barn.cm) }^{b}\end{array}$ & $\begin{array}{c}\text { Calculated } \\
\text { normalized value }\end{array}$ & C/M ratio \\
\hline${ }^{235} \mathrm{U}$ & $2.151 \mathrm{E}-02$ & 0.60 & $4.754 \mathrm{E}-04$ & $2.136 \mathrm{E}-02$ & 0.993 \\
${ }^{236} \mathrm{U}$ & $2.325 \mathrm{E}-03$ & 2.00 & $4.994 \mathrm{E}-05$ & $2.244 \mathrm{E}-03$ & 0.965 \\
${ }^{238} \mathrm{U}$ & $9.915 \mathrm{E}-01$ & 0.05 & $2.210 \mathrm{E}-02$ & $9.929 \mathrm{E}-01$ & 1.001 \\
${ }^{237} \mathrm{~Np}$ & $1.079 \mathrm{E}-04$ & 18.00 & $1.795 \mathrm{E}-06$ & $8.062 \mathrm{E}-05$ & 0.747 \\
${ }^{239} \mathrm{Pu}$ & $3.452 \mathrm{E}-03$ & 0.10 & $7.206 \mathrm{E}-05$ & $3.237 \mathrm{E}-03$ & 0.938 \\
${ }^{240} \mathrm{Pu}$ & $7.219 \mathrm{E}-04$ & 0.30 & $1.561 \mathrm{E}-05$ & $7.013 \mathrm{E}-04$ & 0.971 \\
${ }^{241} \mathrm{Pu}$ & $2.581 \mathrm{E}-04$ & 0.50 & $4.865 \mathrm{E}-06$ & $2.186 \mathrm{E}-04$ & 0.847 \\
${ }^{242} \mathrm{Pu}$ & $2.958 \mathrm{E}-05$ & 1.40 & $5.289 \mathrm{E}-07$ & $2.376 \mathrm{E}-05$ & 0.803 \\
${ }^{241} \mathrm{Am}$ & $2.534 \mathrm{E}-06$ & $-{ }^{c}$ & $9.068 \mathrm{E}-08$ & $4.074 \mathrm{E}-06$ & 1.608 \\
${ }^{243} \mathrm{Am}$ & $1.506 \mathrm{E}-06$ & $-{ }^{c}$ & $2.823 \mathrm{E}-08$ & $1.268 \mathrm{E}-06$ & 0.842 \\
${ }^{242} \mathrm{Cm}$ & $5.926 \mathrm{E}-07$ & 12.00 & $1.011 \mathrm{E}-08$ & $4.542 \mathrm{E}-07$ & 0.766 \\
${ }^{243} \mathrm{Cm}+{ }^{244} \mathrm{Cm}$ & $1.248 \mathrm{E}-07$ & 14.00 & $2.021 \mathrm{E}-09$ & $9.079 \mathrm{E}-08$ & 0.727 \\
${ }^{145} \mathrm{Nd}$ & $5.125 \mathrm{E}-04$ & 2.20 & $1.111 \mathrm{E}-05$ & $4.989 \mathrm{E}-04$ & 0.974 \\
${ }^{146} \mathrm{Nd}$ & $4.447 \mathrm{E}-04$ & 2.00 & $9.293 \mathrm{E}-06$ & $4.175 \mathrm{E}-04$ & 0.939 \\
${ }^{148} \mathrm{Nd}$ & $2.418 \mathrm{E}-04$ & 0.70 & $5.193 \mathrm{E}-06$ & $2.333 \mathrm{E}-04$ & 0.965 \\
\hline
\end{tabular}

$a_{\text {atom density ratio to initial }}{ }^{238} \mathrm{U}$ atom density.

${ }^{b}$ atom density ratio to calculated initial ${ }^{238} \mathrm{U}$ atom density (2.226E-02).

${ }^{c}$ Quoted measurement error so high that measurement judged to have little value.

Table D.21. Pin D2 of GEB-161: Pin power comparison

\begin{tabular}{cccccc}
\hline $\begin{array}{c}\text { Measured normalized } \\
\text { pin power } \\
\text { (avg. of 9 rods =1) }\end{array}$ & $\begin{array}{c}\text { Measurement } \\
\text { error \% }\end{array}$ & $\begin{array}{c}\text { Calculated }{ }^{\mathbf{1 4 0}} \text { Ba } \\
\text { (atoms/barn-cm) }\end{array}$ & $\begin{array}{c}\text { Calculated } \\
\text { normalized pin } \\
\text { power }\end{array}$ \\
\hline 1.110 & 1.7 & $6.072 \mathrm{E}-07$ & 1.1394 & 1.027 & 2.7 \\
\hline
\end{tabular}

Table D.22. Pin D2 of GEB-161: Burnup comparison

\begin{tabular}{cccc}
\hline $\begin{array}{c}\text { Measured pin } \\
\text { burnup Mwd/t }\end{array}$ & $\begin{array}{c}\text { Calculated pin } \\
\text { burnup MWd/t }\end{array}$ & C/M ratio & (C/M-1):100 \\
\hline 13200 & 12647 & 0.958 & -4.2 \\
\hline
\end{tabular}


Table D.23. Pin F6 of GEB-161: Isotopic comparison

(Pin description: $\mathrm{UO}_{2}$ type 7, enrichment $2.56 \mathrm{wt} \%, 2.5 \%{ }^{203} \mathrm{Gd}$ )

\begin{tabular}{cccccc}
\hline Nuclide & $\begin{array}{c}\text { Measured } \\
\text { value }^{a}\end{array}$ & $\begin{array}{c}\text { Measurement } \\
\text { error \% }\end{array}$ & $\begin{array}{c}\text { Calculated atom density } \\
\text { (atoms/barn-cm) }\end{array}$ & $\begin{array}{c}\text { Calculated } \\
\text { normalized value }\end{array}$ & C/M ratio \\
\hline${ }^{235} \mathrm{U}$ & $1.910 \mathrm{E}-02$ & 0.60 & $4.252 \mathrm{E}-04$ & $1.969 \mathrm{E}-02$ & 1.031 \\
${ }^{236} \mathrm{U}$ & $1.352 \mathrm{E}-03$ & 2.00 & $2.846 \mathrm{E}-05$ & $1.318 \mathrm{E}-03$ & 0.975 \\
${ }^{238} \mathrm{U}$ & $9.942 \mathrm{E}-01$ & 0.05 & $2.145 \mathrm{E}-02$ & $9.936 \mathrm{E}-01$ & 0.999 \\
${ }^{237} \mathrm{~Np}$ & $\mathrm{NA}$ & & $1.110 \mathrm{E}-06$ & $5.139 \mathrm{E}-05$ & $\mathrm{NA}$ \\
${ }^{239} \mathrm{Pu}$ & $3.418 \mathrm{E}-03$ & 0.10 & $7.282 \mathrm{E}-05$ & $3.372 \mathrm{E}-03$ & 0.987 \\
${ }^{240} \mathrm{Pu}$ & $5.297 \mathrm{E}-04$ & 0.40 & $1.192 \mathrm{E}-05$ & $5.522 \mathrm{E}-04$ & 1.043 \\
${ }^{241} \mathrm{Pu}$ & $1.788 \mathrm{E}-04$ & 0.50 & $3.760 \mathrm{E}-06$ & $1.741 \mathrm{E}-04$ & 0.974 \\
${ }^{242} \mathrm{Pu}$ & $1.473 \mathrm{E}-05$ & 1.40 & $2.944 \mathrm{E}-07$ & $1.364 \mathrm{E}-05$ & 0.926 \\
${ }^{241} \mathrm{Am}$ & $\mathrm{NA}$ & & $6.280 \mathrm{E}-08$ & $2.908 \mathrm{E}-06$ & NA \\
${ }^{243} \mathrm{Am}$ & $\mathrm{NA}$ & & $1.341 \mathrm{E}-08$ & $6.211 \mathrm{E}-07$ & NA \\
${ }^{242} \mathrm{Cm}$ & $\mathrm{NA}$ & & $5.852 \mathrm{E}-09$ & $2.710 \mathrm{E}-07$ & NA \\
${ }^{243} \mathrm{Cm}+{ }^{244} \mathrm{Cm}$ & $\mathrm{NA}$ & & $8.540 \mathrm{E}-10$ & $3.955 \mathrm{E}-08$ & NA \\
${ }^{145} \mathrm{Nd}$ & $2.815 \mathrm{E}-04$ & 2.20 & $6.095 \mathrm{E}-06$ & $2.823 \mathrm{E}-04$ & 1.003 \\
${ }^{146} \mathrm{Nd}$ & $2.343 \mathrm{E}-04$ & 2.00 & $5.048 \mathrm{E}-06$ & $2.338 \mathrm{E}-04$ & 0.998 \\
${ }^{148} \mathrm{Nd}$ & $1.313 \mathrm{E}-04$ & 0.70 & $2.878 \mathrm{E}-06$ & $1.333 \mathrm{E}-04$ & 1.015 \\
\hline
\end{tabular}

${ }^{a}$ atom density ratio to initial ${ }^{238} \mathrm{U}$ atom density.

${ }^{b}$ atom density ratio to calculated initial ${ }^{238} \mathrm{U}$ atom density $(2.159 \mathrm{E}-02)$.

Table D.24. Pin F6 of GEB-161: Pin power comparison

\begin{tabular}{ccccccc}
\hline $\begin{array}{c}\text { Measured normalized } \\
\text { pin power } \\
\text { (avg. of 9 rods =1) }\end{array}$ & $\begin{array}{c}\text { Measurement } \\
\text { error \% }\end{array}$ & $\begin{array}{c}\text { Calculated }{ }^{140} \text { Ba } \\
\text { (atoms/barn.cm) }\end{array}$ & $\begin{array}{c}\text { Calculated } \\
\text { normalized pin } \\
\text { power }\end{array}$ \\
\hline 0.881 & 1.7 & $4.780 \mathrm{E}-07$ & 0.897 & 1.018 & 1.8 \\
\hline
\end{tabular}

Table D.25. Pin F6 of GEB-161: Burnup comparison

\begin{tabular}{cccc}
\hline $\begin{array}{c}\text { Measured pin } \\
\text { burnup MWd/t }\end{array}$ & $\begin{array}{c}\text { Calculated pin } \\
\text { burnup MWd/t }\end{array}$ & C/M ratio & (C/M-1)·100 \\
\hline 7161 & 7279 & 1.016 & 1.6 \\
\hline
\end{tabular}


Table D.26. Pin G1 of GEB-161: Isotopic comparison

(Pin description: $\mathrm{UO}_{2}$ type 3, enrichment $1.69 \mathrm{wt} \%$ )

\begin{tabular}{cccccc}
\hline Nuclide & $\begin{array}{c}\text { Measured } \\
\text { value }^{a}\end{array}$ & $\begin{array}{c}\text { Measurement } \\
\text { error \% }\end{array}$ & $\begin{array}{c}\text { Calculated atom density } \\
\text { (atoms/barn'cm) }\end{array}$ & $\begin{array}{c}\text { Calculated } \\
\text { normalized value }\end{array}$ & C/M ratio \\
\hline${ }^{235} \mathrm{U}$ & $7.193 \mathrm{E}-03$ & 0.80 & $1.602 \mathrm{E}-04$ & $7.081 \mathrm{E}-03$ & 0.984 \\
${ }^{236} \mathrm{U}$ & $1.734 \mathrm{E}-03$ & 2.00 & $3.674 \mathrm{E}-05$ & $1.624 \mathrm{E}-03$ & 0.936 \\
${ }^{238} \mathrm{U}$ & $9.908 \mathrm{E}-01$ & 0.05 & $2.243 \mathrm{E}-02$ & $9.910 \mathrm{E}-01$ & 1.000 \\
${ }^{237} \mathrm{~Np}$ & $8.723 \mathrm{E}-05$ & 18.00 & $1.608 \mathrm{E}-06$ & $7.108 \mathrm{E}-05$ & 0.815 \\
${ }^{239} \mathrm{Pu}$ & $3.067 \mathrm{E}-03$ & 0.10 & $6.638 \mathrm{E}-05$ & $2.933 \mathrm{E}-03$ & 0.956 \\
${ }^{240} \mathrm{Pu}$ & $1.105 \mathrm{E}-03$ & 0.30 & $2.525 \mathrm{E}-05$ & $1.116 \mathrm{E}-03$ & 1.010 \\
${ }^{241} \mathrm{Pu}$ & $3.825 \mathrm{E}-04$ & 0.50 & $7.926 \mathrm{E}-06$ & $3.502 \mathrm{E}-04$ & 0.916 \\
${ }^{242} \mathrm{Pu}$ & $8.786 \mathrm{E}-05$ & 1.40 & $1.759 \mathrm{E}-06$ & $7.771 \mathrm{E}-05$ & 0.884 \\
${ }^{241} \mathrm{Am}$ & $2.613 \mathrm{E}-06$ & $-{ }^{c}$ & $1.461 \mathrm{E}-07$ & $6.456 \mathrm{E}-06$ & 2.471 \\
${ }^{243} \mathrm{Am}$ & $5.161 \mathrm{E}-06$ & $-{ }^{c}$ & $1.135 \mathrm{E}-07$ & $5.014 \mathrm{E}-06$ & 0.972 \\
${ }^{242} \mathrm{Cm}$ & $1.399 \mathrm{E}-06$ & 12.00 & $2.840 \mathrm{E}-08$ & $1.255 \mathrm{E}-06$ & 0.897 \\
${ }^{243} \mathrm{Cm}+{ }^{244} \mathrm{Cm}$ & $5.333 \mathrm{E}-07$ & 14.00 & $1.047 \mathrm{E}-08$ & $4.625 \mathrm{E}-07$ & 0.867 \\
${ }^{145} \mathrm{Nd}$ & $4.469 \mathrm{E}-04$ & 2.20 & $1.028 \mathrm{E}-05$ & $4.541 \mathrm{E}-04$ & 1.016 \\
${ }^{146} \mathrm{Nd}$ & $4.105 \mathrm{E}-04$ & 2.00 & $8.974 \mathrm{E}-06$ & $3.966 \mathrm{E}-04$ & 0.966 \\
${ }^{148} \mathrm{Nd}$ & $2.287 \mathrm{E}-04$ & 0.70 & $5.090 \mathrm{E}-06$ & $2.249 \mathrm{E}-04$ & 0.984 \\
\hline${ }^{6}$ & & &
\end{tabular}

${ }^{a}$ atom density ratio to initial ${ }^{238} \mathrm{U}$ atom density.

${ }^{b}$ atom density ratio to calculated initial ${ }^{238} \mathrm{U}$ atom density (2.263E-02).

${ }^{c}$ Quoted measurement error so high that measurement judged to have little value.

Table D.27. Pin G1 of GEB-161: Pin power comparison

\begin{tabular}{cccccc}
\hline $\begin{array}{c}\text { Measured normalized } \\
\text { pin power } \\
\text { (avg. of 9 rods=1) }\end{array}$ & $\begin{array}{c}\text { Measurement } \\
\text { error \% }\end{array}$ & $\begin{array}{c}\text { Calculated }{ }^{140} \text { Ba } \\
\text { (atoms/barn-cm) }\end{array}$ & $\begin{array}{c}\text { Calculated } \\
\text { (avg. of 9 rods = 1) } \\
\text { power }\end{array}$ & C/M ratio & (C/M-1)-100 \\
\hline 0.990 & 1.7 & $5.454 \mathrm{E}-07$ & 1.0235 & 1.034 & 3.4 \\
\hline
\end{tabular}

Table D.28. Pin D3 of GEB-161: Burnup comparison

\begin{tabular}{cccc}
\hline $\begin{array}{c}\text { Measured pin } \\
\text { burnup Mwd/t }\end{array}$ & $\begin{array}{c}\text { Calculated pin } \\
\text { burnup MWd/t }\end{array}$ & C/M ratio & (C/M-1)·100 \\
\hline 12500 & 12361 & 0.989 & -1.1 \\
\hline
\end{tabular}


Table D.29. Average $\mathrm{C} / \mathrm{E}$ for the isotope densities, relative power distribution and burnup of $\mathrm{MOX}$ and $\mathrm{UO}_{2}$ pins of central assembly GEB-161

\begin{tabular}{cccc}
\hline Isotope & $\begin{array}{c}\text { Measurement } \\
\text { error (\%) }\end{array}$ & C/M of MOX pins & $\begin{array}{c}\text { C/M of UO } 2 \text { pins } \\
\text { (excludes Gd pin F6) }\end{array}$ \\
\hline${ }^{235} \mathrm{U}$ & 0.80 & 1.0022 & 0.9885 \\
${ }^{236} \mathrm{U}$ & 2.00 & 1.0137 & 0.9260 \\
${ }^{238} \mathrm{U}$ & 0.05 & 0.9998 & 1.0005 \\
${ }^{237} \mathrm{~Np}$ & 18.00 & 0.7867 & 0.8005 \\
${ }^{239} \mathrm{Pu}$ & 0.10 & 0.9862 & 0.9472 \\
${ }^{240} \mathrm{Pu}$ & 0.30 & 0.9977 & 0.9755 \\
${ }^{241} \mathrm{Pu}$ & 0.50 & 1.0017 & 0.8645 \\
${ }^{242} \mathrm{Pu}$ & 1.40 & 0.9470 & 0.8195 \\
${ }^{241} \mathrm{Am}$ & $30 \mathrm{MOX}, \mathrm{UO}{ }_{2}{ }^{24}$ & 0.3762 & 1.6130 \\
${ }^{243} \mathrm{Am}$ & $30 \mathrm{MOX}, \mathrm{UO}{ }_{2}{ }^{a}$ & 0.9545 & 0.8335 \\
${ }^{242} \mathrm{Cm}$ & 12.00 & 0.1782 & 0.7785 \\
${ }^{243} \mathrm{Cm}+{ }^{244} \mathrm{Cm}$ & 14.00 & 0.8177 & 0.7375 \\
${ }^{145} \mathrm{Nd}$ & 2.20 & 0.9775 & 0.9980 \\
${ }^{146} \mathrm{Nd}$ & 2.00 & 0.9685 & 0.9665 \\
${ }^{148} \mathrm{Nd}$ & 0.70 & 0.9802 & 0.9805 \\
$\mathrm{Pin}$ power & 1.7 & 0.9777 & 1.0175 \\
$\mathrm{Burnup}$ & $\mathrm{NA}$ & 1.0167 & 0.9817 \\
\hline
\end{tabular}

${ }^{a}$ Quoted measurement error so high that measurement was judged to have little value.

Table D.30. ${ }^{242} \mathrm{Cm}$ and ${ }^{243} \mathrm{Am}$ isotopics fractions for central assembly GEB-161

$\mathrm{Cm}_{\text {ratio }^{a}} \mathrm{Am}_{\text {ratio }}{ }^{b}$

Measurement $t^{c}(\%)$ Calculations (\%) Measurement $^{d}(\%)$ Calculations (\%)

\begin{tabular}{lllll}
\hline D3 (MOX pin) & 82.9 & 51.2 & 24.2 & 43.6 \\
D5 (MOX pin) & 88.4 & 62.8 & 14.1 & 27.7 \\
E3 (MOX pin) & 83.1 & 50.9 & 21.9 & 43.1 \\
E4 (MOX pin) & 88.4 & 62.9 & 12.3 & 28.1 \\
C2 (UO 2 pin) & 80.8 & 81.8 & 21.9 & 27.2 \\
D1 (UO 2 pin) & 76.0 & 77.2 & 55.3 & 36.1 \\
D2 (UO 2 pin) & 82.6 & 83.3 & 37.3 & 23.7 \\
F6 (Gd pins) & (NA) & 87.3 & (NA) & 17.6 \\
G1 (UO 2 pin) & 72.4 & 73.1 & 66.4 & 43.7 \\
\hline
\end{tabular}

${ }^{a_{242}} \mathrm{Cm} /\left({ }^{242} \mathrm{Cm}+{ }^{243} \mathrm{Cm}+{ }^{244} \mathrm{Cm}\right)$

${ }^{b_{243}} \mathrm{Am} /\left({ }^{241} \mathrm{Am}+{ }^{243} \mathrm{Am}\right)$

${ }^{c}$ Error is $1.2 \%$.

${ }^{d}$ Error is $2.8 \%$ for MOX pins and $68 \%$ for $\mathrm{UO}_{2}$ pins. 


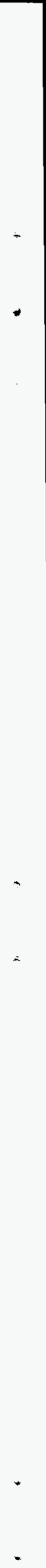




\section{APPENDIX E. SCALE INPUT LISTING}

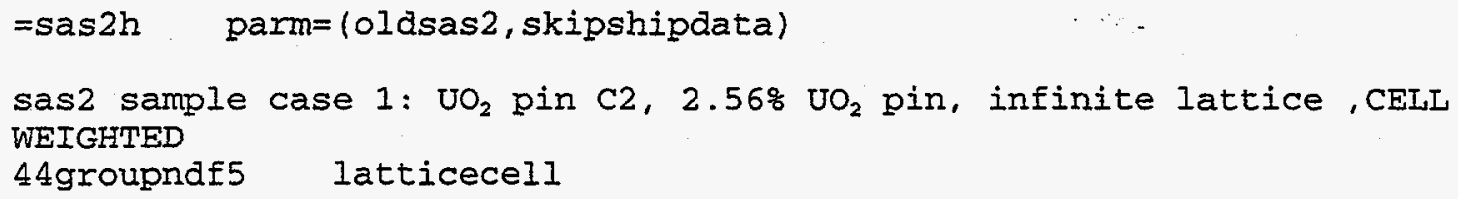

- this part of input: mixtures of fuel-pin-unit-cell

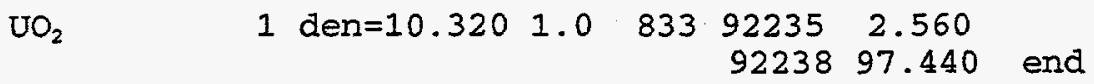

' ....above method uses wt $\%$ 's of $u / p u$ isotopes, add additional xsecs for following

\begin{tabular}{|c|c|c|c|c|}
\hline-234 & 10 & $1.00 e-20$ & 833 & end \\
\hline$u-236$ & 10 & $1.00 e-20$ & 833 & end \\
\hline$u-237$ & 10 & $1.00 e-20$ & 833 & end \\
\hline$n p-237$ & 10 & $1.00 e-20$ & 833 & end \\
\hline$n p-238$ & 10 & $1.00 e-20$ & 833 & end \\
\hline$p u-238$ & 10 & $1.00 e-20$ & 833 & end \\
\hline $\mathrm{pu}-242$ & 10 & $1.00 e-20$ & 833 & end \\
\hline$a m-241$ & 10 & $1.00 e-20$ & 833 & end \\
\hline$a m-242$ & 10 & $1.00 e-20$ & 833 & end \\
\hline$a m-242 m$ & 10 & $1.00 e-20$ & 833 & end \\
\hline$a m-243$ & 10 & $1.00 e-20$ & 833 & end \\
\hline $\mathrm{cm}-242$ & 10 & $1.00 e-20$ & 833 & end \\
\hline $\mathrm{cm}-243$ & 10 & $1.00 e-20$ & 833 & end \\
\hline $\mathrm{cm}-244$ & 10 & $1.00 e-20$ & 833 & ad \\
\hline $\mathrm{cm}-245$ & 10 & $1.00 e-20$ & 833 & end \\
\hline ' fission & produc & ts & & \\
\hline$k r-83$ & 10 & $1.00 e-20$ & 833 & \\
\hline sr -90 & 10 & $1.00 e-20$ & 833 & \\
\hline zr -93 & 10 & $1.00 e-20$ & 833 & ad \\
\hline$z r-95$ & 10 & $1.00 e-20$ & 833 & $1 d$ \\
\hline$z r-96$ & 10 & $1.00 e-20$ & 833 & \\
\hline$n b-95$ & 10 & $1.00 e-20$ & 833 & d \\
\hline mo-95 & 10 & $1.00 e-20$ & 833 & \\
\hline mo-97 & 10 & $1.00 e-20$ & 833 & \\
\hline mo-98 & 10 & $1.00 e-20$ & 833 & d \\
\hline mo-100 & 10 & $1.00 e-20$ & 833 & id \\
\hline tc-99 & 10 & $1.00 e-20$ & 833 & d \\
\hline ru-100 & 10 & $1.00 e-20$ & 833 & \\
\hline ru-101 & 10 & $1.00 e-20$ & 833 & $d$ \\
\hline ru-102 & 10 & $1.00 e-20$ & 833 & \\
\hline ru-103 & 10 & $1.00 e-20$ & 833 & \\
\hline ru-104 & 10 & $1.00 e-20$ & 833 & end \\
\hline ru-106 & 10 & $1.00 \mathrm{e}-20$ & 833 & nd \\
\hline$r h-103$ & 10 & $1.00 e-20$ & 833 & \\
\hline rh-105 & 10 & $1.00 e-20$ & 833 & a \\
\hline$p d-104$ & 10 & $1.00 e-20$ & 833 & \\
\hline $\mathrm{pd}-105$ & 10 & $1.00 e-20$ & 833 & \\
\hline$p d-106$ & 10 & $1.00 e-20$ & 833 & \\
\hline pd-107 & 10 & $1.00 e-20$ & 833 & \\
\hline$p d-108$ & 10 & $1.00 e-20$ & 833 & \\
\hline ag-109 & 10 & $1.00 e-20$ & 833 & \\
\hline$=d-110$ & 1 & $1.00 e-20$ & 833 & \\
\hline
\end{tabular}




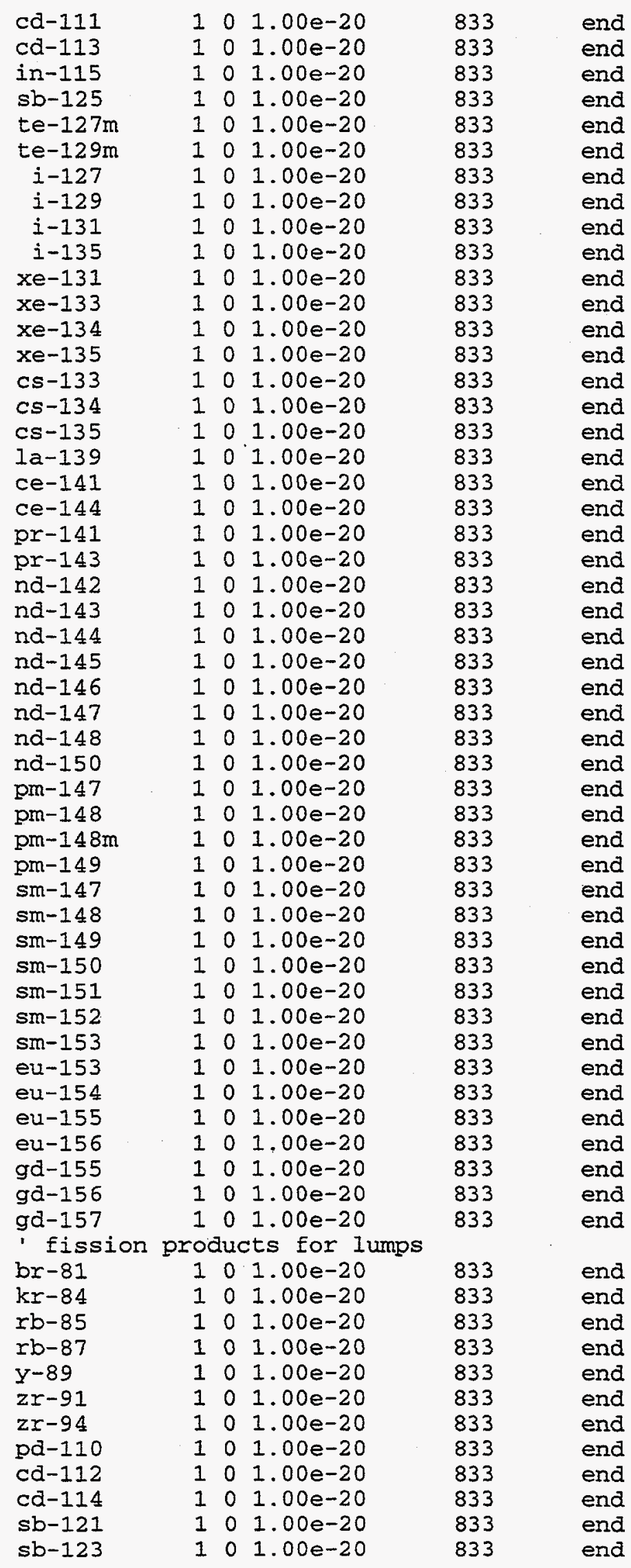




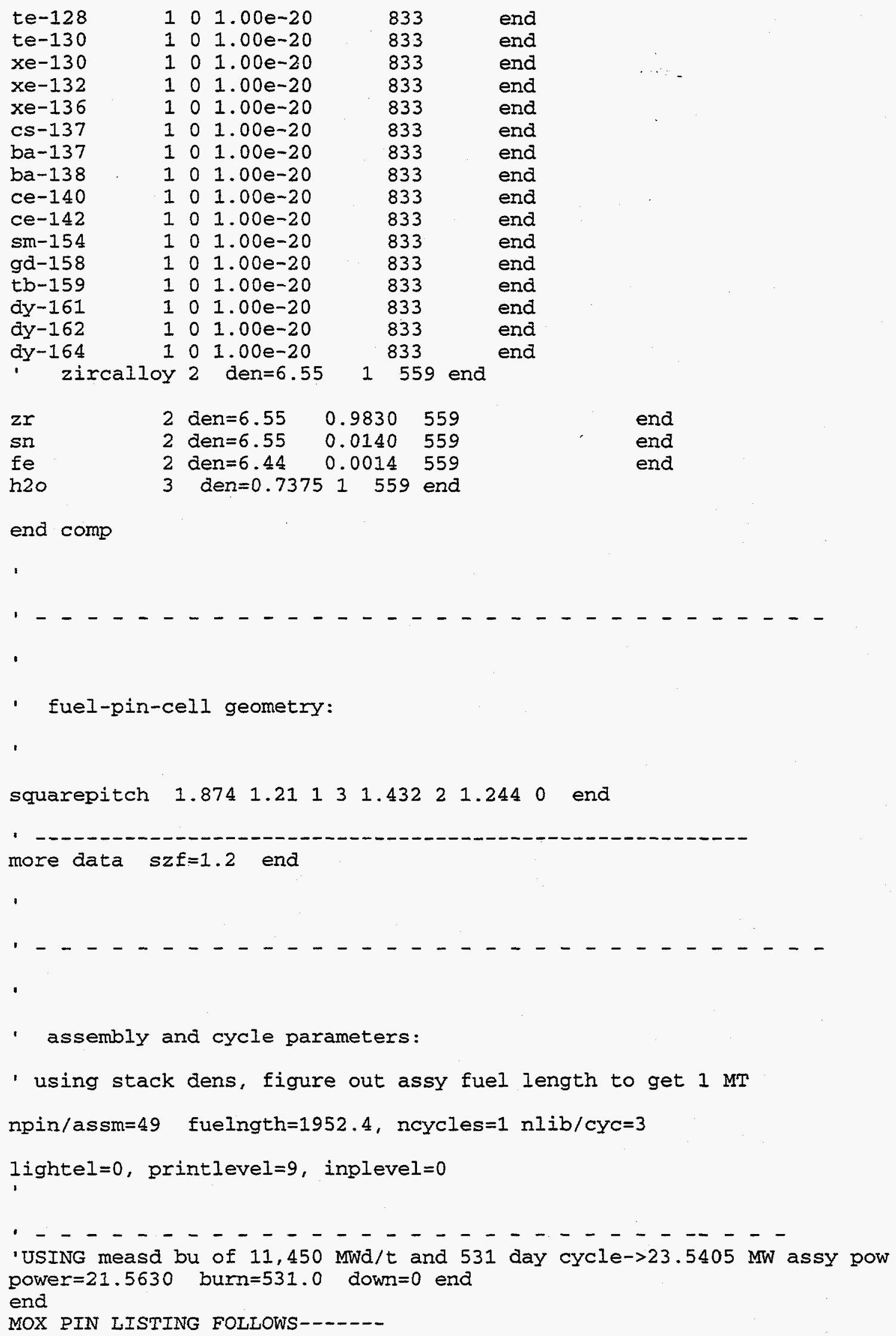


$=\operatorname{sas} 2 \mathrm{~h} \quad$ parm $=($ oldsas 2, skipshipdata $)$

sas2 sample case 1: MOX pin D5, $90 \%$ solid pin, infinite latțice ,CELL WEIGHTED

44 groupnaf5 latticecell

- this part of input: mixtures of fuel-pin-unit-cell

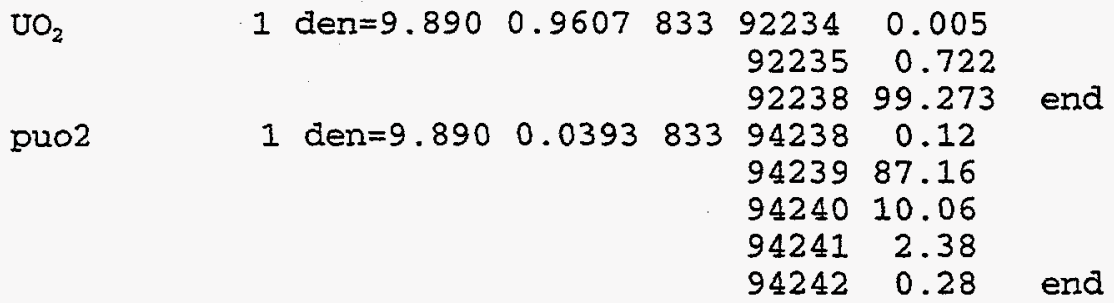

1 ....above method uses wt $\%$ 's of $u / p u$ isotopes, add additional xsecs for following

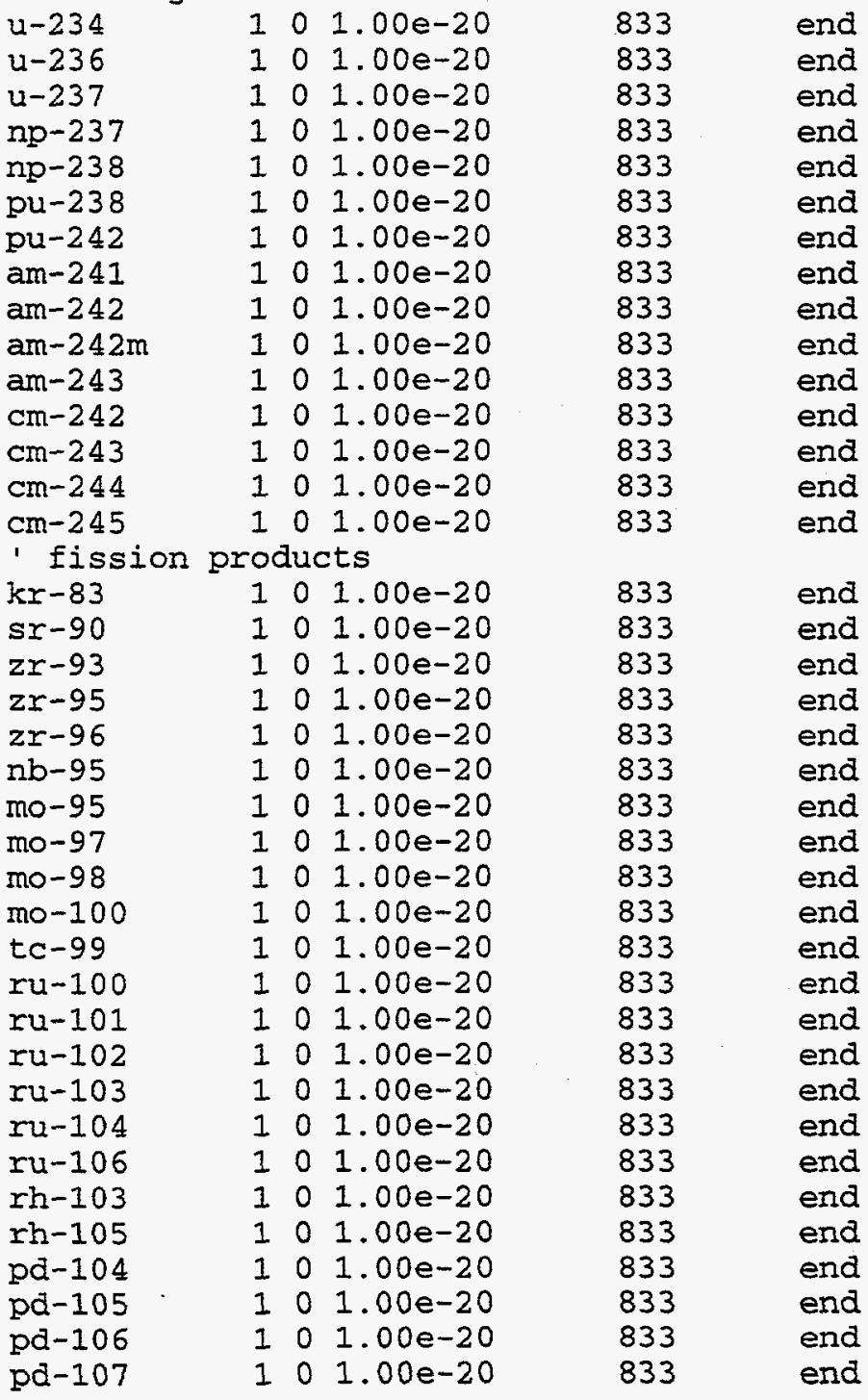




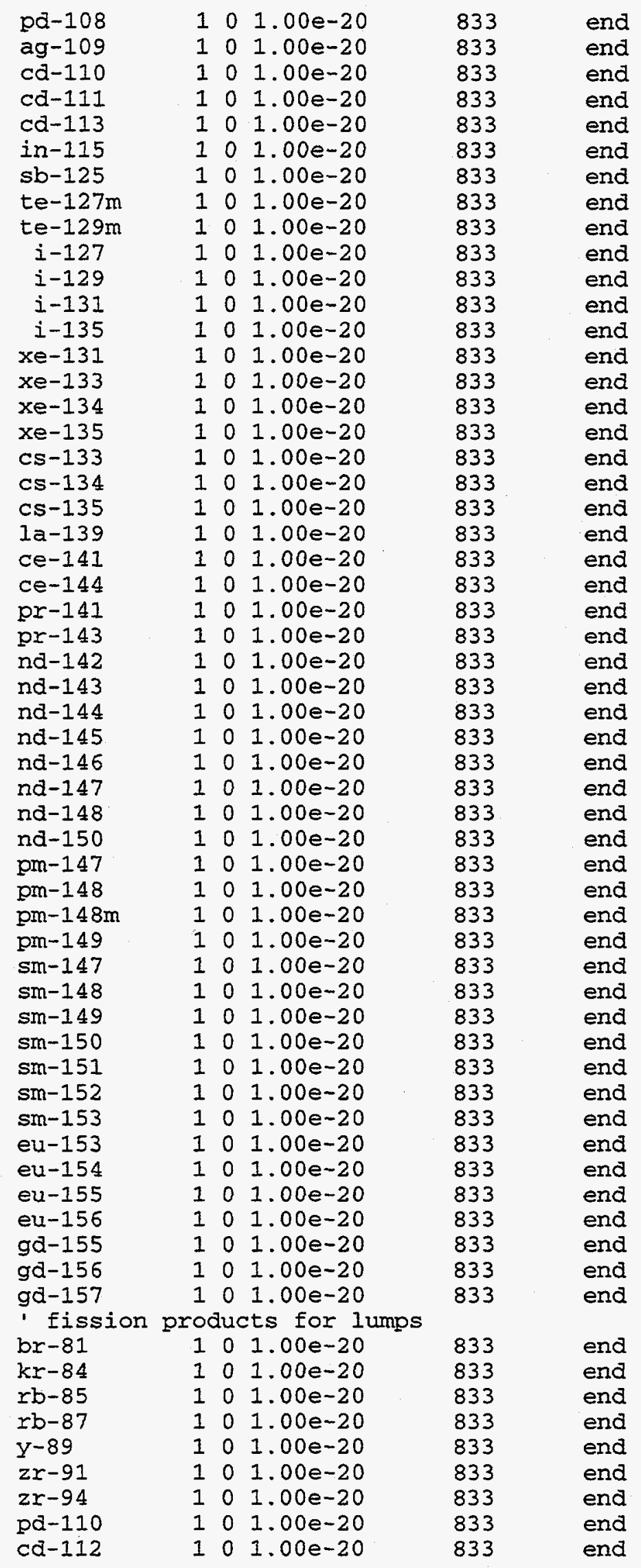




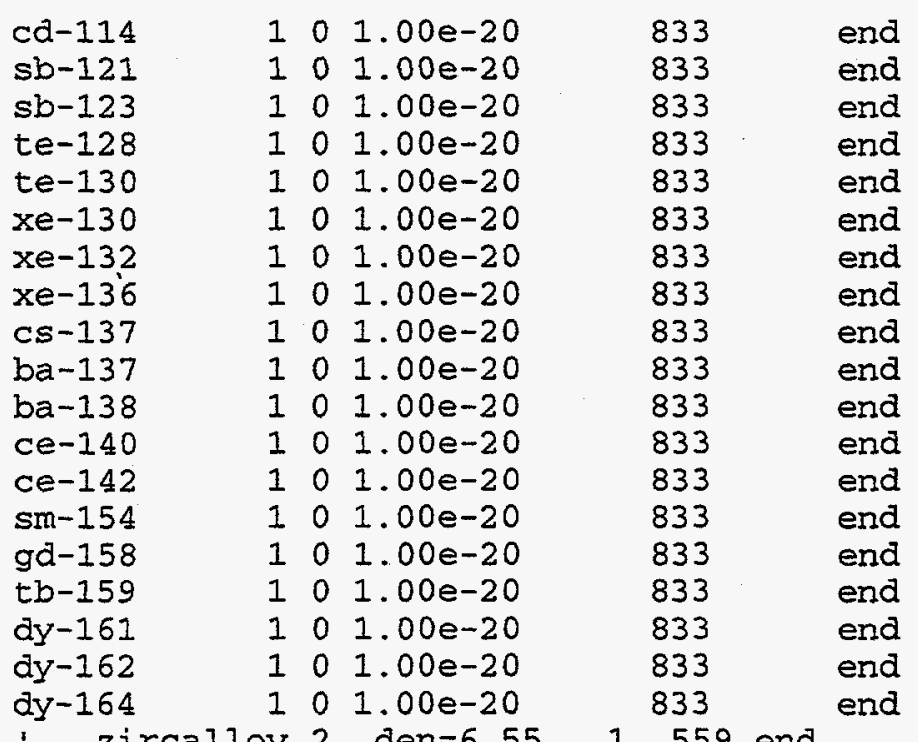

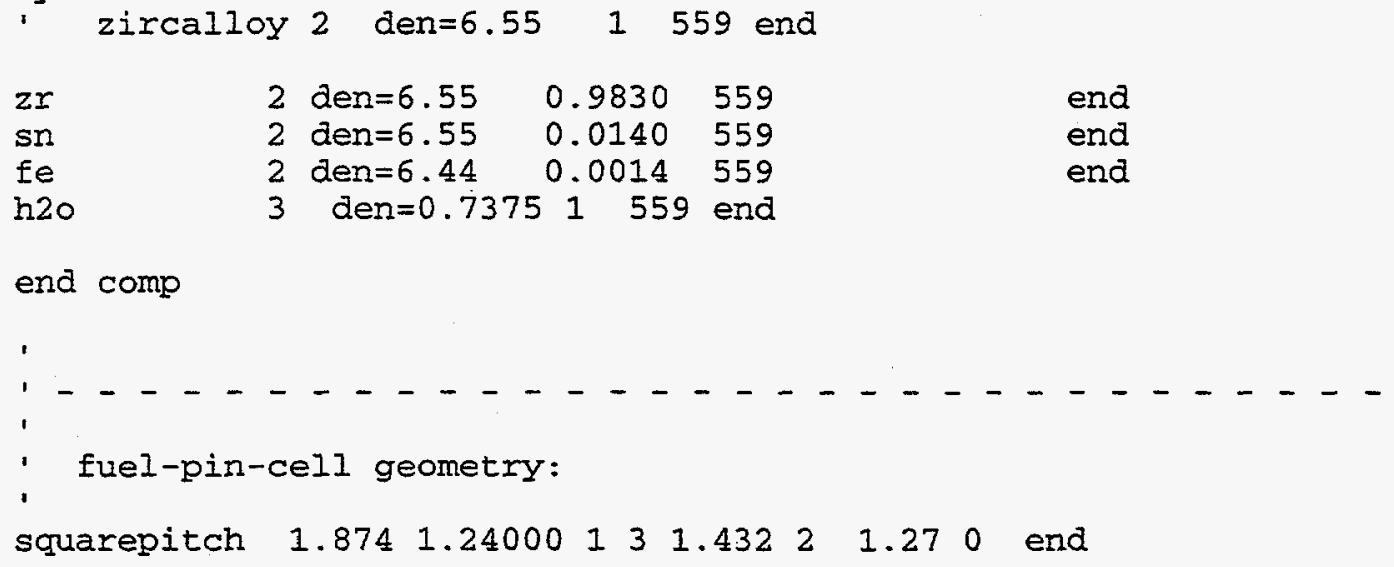




\section{ACKNOWLEDGEMENTS}

This work was sponsored by the U.S. Department of Energy's Fissile Materials Disposition Program in order to partially fulfill milestone 98-9 of the Joint United States/Russian Federation program in plutonium disposition. Milestone $98-9$ identifies a task to evaluate past U.S. mixed oxide irradiations for use as reactor physics benchmarks. The authors would like to thank Ted Shannon of Commonwealth Edison for his consultation and thoughts. The authors would also like to acknowledge Ruth Lawson for her assistance with the preparation of the report. Brian Murphy is acknowledged for supplying an initial HELIOS model that helped to accelerate model development. 



\section{'INTERNAL DISTRIBUTION}

1. B. B. Bevard

2. S. M. Bowman

3. B. L. Broadhead

4. B. S. Cowell

5. W. G. Craddick

6. M. D. DeHart

7. F. C. Difilippo

8-12. S. E. Fisher

13. E. C. Fox

14. J. C. Gehin

15. S. R. Greene

16. O. W. Hermann

17. S. A. Hodge

18. D. T. Ingersoll

19. M. A. Kuliasha

20. L. C. Leal
21. G. E. Michaels

22. D. L. Moses

23. B. D. Murphy

24. D. G. O'Connor

25. C. V. Parks

26-30. R. T. Primm, III

31. R. W. Roussin

32. J. C. Ryman

33. D. J. Spellman

34. R. M. Westfall

35. B. A. Worley

36. R. Q. Wright

37-38. Laboratory Records (for submission to OSTT)

39. Laboratory Records-RC

40. Central Research Library

41. ORNL Patent Section

\section{EXTERNAL DISTRIBUTION}

42. M. L. Adams, Dept. of Nuclear Engineering, Texas A\&M University, Zachry 129, College Station, TX 77843

43. D. Alberstein, Los Alamos National Laboratory, P.O. Box 1663, MS-K575, Los Alamos, NM 87545

44. J. F. Baker, Office of Fissile Materials Disposition, Dept. of Energy, MD-1, 1000 Independence Avenue SW, Forrestal Bldg., 6G-050, Washington, DC 20585

45. J. Buksa, Los Alamos National Laboratory, P.O. Box 1663, Los Alamos, NM 87545

46. H. R. Canter, Office of Fissile Materials Disposition, Dept. of Energy, MD-1/2, 1000 Independence Avenue SW, Building 3F043, Washington, DC 20585

47. G. S. Chang, INEEL, P.O. Box 1625, MS-3885, Idaho Falls, ID 83415-3885

48. Ron Chinn, Commonwealth Edison Company, 1400 Opus Place, Suite 400, Downers Grove, Illinois 60515

49. T. Cremers, Los Alamos National Laboratory, P.O. Box 1663, Los Alamos, NM 87545

50. A. I. Cygelman, Department of Energy, 1000 Independence Ave. SW, Forrestal Building 3F043, Washington, DC 20585

51. George A. Davis, ABB-Combustion Engineering, 2000 Day Hill, MC-9310-0422, Windsor, Connecticut 06095

52. Ed Ehrlich, General Electric, 175 Curtner Avenue, San Jose, California 95125

53. L. Groves, Sandia National Laboratories, P.O. Box 969, Livermore, CA 94551

54. D. Harrison, Department of Energy, 101 Convention Center Drive, Suite P200, Las Vegas, NV 89109

55. C. Jaeger, Sandia National Laboratories, P.O. Box 5800, Albuquerque, NM 87185-0759

56. J. D. Nulton, Office of Fissile Materials Disposition, Dept. of Energy, MD-4, 1000 Independence Avenue SW, Washington, DC 20585

57. Odelli Ozer, Electric Power Research Institute, 3412 Hillview Avenue, Palo Alto, California 94304

58. S. L. Passman, Sandia National Laboratories, 1401 Wilson Blvd., Suite 1050, Arlington, VA 22209

59. D. Peko, Department of Energy, 1000 Independence Ave. SW, Forrestal Building 3F042, Washington, DC 20585

60. K. K. S. Pillay, Los Alamos National Laboratory, Los Alamos, NM 87545

61. P. T. Rhoads, Office of Fissile Materials Disposition, Dept. of Energy, MD-4, 1000 Independence Avenue SW, Forrestal Building 3F043, Washington, DC 20585

62. J. M. Ryskamp, INEEL, P.O. Box 1625, MS-3885, Idaho Falls, ID 83415-3885

63. S. S. Sareen, Sandia National Laboratories, 2650 Park Tower Drive, Suite 800, Vienna, VA 22180 
64. Theodore Shannon, Commonwealth Edison Company, 1400 Opus Place, Suite 400, Downers Grove, Illinois 60515

65. J. H. Thompson, Office of Fissile Materials Disposition, Dept. of Energy; MD-4, 1000 Independence Avenue SW, Washington, DC 20585

66. Michael L. Travis, Westinghouse Electric Corporation, P.O. Box 355, Pittsburgh, Pennsylvania 15230

67. R. Zurn, Sandia National Laboratories, P.O. Box 969, Livermore, CA 94551

68. Rosa Yang, Electric Power Research Institute, 3412 Hillview Avenue, Palo Alto, California 94304

69-70. Office of Scientific and Technical Information, U.S. Department of Energy, P.O. Box 62, Oak Ridge, TN 37831 